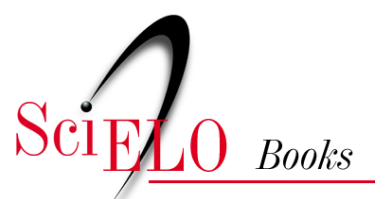

\title{
A formação ética dos médicos saindo da adolescência com a vida (dos outros) nas mãos
}

\author{
Sérgio Rego
}

\section{SciELO Books / SciELO Livros / SciELO Libros}

REGO, S. A formação ética dos médicos: saindo da adolescência com a vida (dos outros) nas mãos [online]. Rio de Janeiro: Editora FIOCRUZ, 2003, 183 p. ISBN 978-85-7541-324-1. https://doi.org/10.7476/9788575413241.

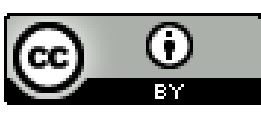

All the contents of this work, except where otherwise noted, is licensed under a Creative Commons Attribution 4.0 International license.

Todo o conteúdo deste trabalho, exceto quando houver ressalva, é publicado sob a licença Creative Commons Atribição 4.0. 
A Formação Ética dos Médicos

saindo da adolescência com a vida

(dos outros)

nas mãos 


\section{FUNDAÇÃO OSWALDO CRUZ}

Presidente

Paulo Gadelha

Vice-Presidente de Ensino, Informação e Comunicação

Nísia Trindade Lima

\section{EDITORA FIOCRUZ}

Diretora

Nísia Trindade Lima

Editor Executivo

João Carlos Canossa Mendes

Editores Científicos

Gilberto Hochman e Ricardo Ventura Santos

Conselho Editorial

Ana Lúcia Teles Rabello

Armando de Oliveira Schubach

Carlos E. A. Coimbra Jr.

Gerson Oliveira Penna

Joseli Lannes Vieira

Ligia Vieira da Silva

Maria Cecília de Souza Minayo 


\title{
A Formação Ética dos Médicos \\ saindo da adolescência com a vida (dos outros) \\ nas mãos
}

\section{Sérgio Rego}

\author{
2a reimpressão
}

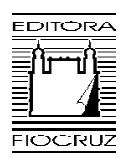


Copyright (C) 2003 do autor

Todos os direitos desta edição reservados à

FUNDAÇÃO OSWALDO CRUZ/EDITORA

ISBN: 85-7541-021-0

1a edição: 2003 | 1a reimpressão: 2005 | 2a reimpressão: 2012

Capa, projeto gráfico e editoração eletrônica

Angélica Mello e Daniel Pose

Preparação de originais, copidesque e revisão

Ana Tereza de Andrade e Janaina S. Silva

Catalogação-na-fonte

Centro de Informação Científica e Tecnológica

Biblioteca Lincoln de Freitas Filho

R343f Rego, Sérgio

A Formação Ética dos Médicos: saindo da adolescência com a vida (dos outros) nas mãos. / Sérgio Rego. Rio de Janeiro: Editora FlOCRUZ, 2003.

$169 \mathrm{p}$.

1. Educação Médica. 2. Ética Médica. 3. Estudantes de Medicina. 11.Título.

CDD - 20.ed. - 610.696

2012

Editora Fiocruz

Av. Brasil, 4036 - 1 andar - sala 112 - Manguinhos

21040-361 - Rio de Janeiro - RJ

Tels.: (21) 3882-9039 e 3882-9041

Telefax: (21) 3882-9006

www.fiocruz.br

e-mail: editora@fiocruz.br 
Nada é impossível de mudar

$\mathrm{Na}$ aparência singelo.

E examinai, sobretudo, o que parece habitual. Suplicamos expressamente:

Não aceiteis o que é de hábito

Como coisa natural,

Pois em tempo de desordem sangrenta,

De confusão organizada,

De arbitrariedade consciente,

De humanidade desumanizada,

Nada deve parecer natural

Brecht (1983: 45) 



\section{Sumário}

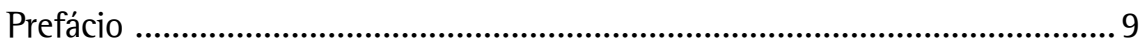

Apresentação ................................................................................................. 13

1. Educação Médica: história e questões .......................................................... 21

2. Introdução ao Estudo da Formação Moral

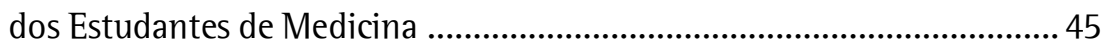

3. Teoria do Desenvolvimento Moral de Jean Piaget

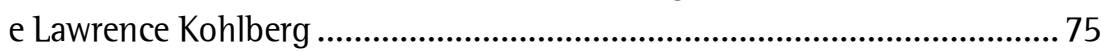

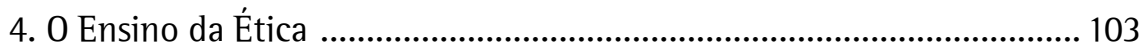

5. Os Estudantes de Medicina e seus Valores …........................................... 123

6. A Vivência de Situação Envolvendo Questões Éticas ............................... 139

7. As Possibilidades e os Limites da Educação Moral ..................................... 165

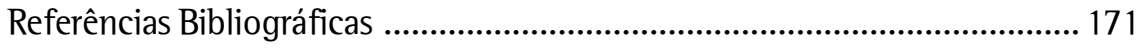





\section{Prefácio}

0 livro do médico, bioeticista e educador Sérgio Rego, sobre a formação ética dos estudantes de medicina no Brasil, que tenho o prazer de apresentar ao leitor brasileiro interessado na problemática da humanização da prática médica na era da crescente, acelerada e, para alguns, impositiva incorporação tecnocientífica - supostamente desumanizante -, tem muitos méritos.

Tais méritos são de duas ordens: teórica e prática. Teórica porque, dialogando criticamente com a literatura pertinente e atualizada sobre a formação moral, abre um campo de reflexão para outras pesquisas sobre a ética profissional, e não somente a médica, demonstrando que uma bioética tardia, como é a brasileira, pode ser, ao mesmo tempo, culturalmente 'antropofágica' e criativa. Prático porque, adaptando os instrumentos teóricos à realidade concreta da formação médica no Brasil, abre a possibilidade não só de fundamentar as críticas de tal formação, mas também de tentar modificá-la graças a meios legítimos e compartilháveis da práxis.

Em outras palavras, este livro responde ao duplo desafio de conhecer a qualidade da formação ética dos futuros médicos nas escolas de medicina do Brasil e, depois de ter detectado suas insuficiências, de saber se é possivel reformar, e como tal formação, adaptando-a às características éticas desejáveis de uma profissão em um país que se insere em um mundo globalizado, mas não necessariamente integrado.

Sem querer indicar pistas de leitura e prejudicar, assim, o prazer da descoberta do leitor, destacarei, a seguir, dentre os muitos méritos, aqueles que considero mais significativos do ponto de vista da construção do campo da ética aplicada e da bioética em nosso país.

Um primeiro mérito é certamente a preocupação profissional e acadêmica do autor em detectar, analisar e esclarecer o que é visto hoje como 'problema' da 
formação do futuro médico no Brasil, ou seja, as insuficiências na integração entre sua competência técnica, via de regra atualizada, e sua competência ética, quase que integralmente moldada na ética médica tradicional, desconectada dos avanços cognitivos e práticos trazidos pela bioética contemporânea. De fato, este problema é determinado, por um lado, pela tensão crescente entre complexificação do saber (bio)médico e a inelutável especialização de seus âmbitos, e, por outro, pela necessidade de integrar as competências específicas na prática concreta do exercício profissional da maneira mais competente possivel, sabendo que os 'objetos' de tal prática são de fato 'objetos-sujeitos' ou pessoas inseridas em um mundo de conflitos de interesses e valores.

Certamente, este não é um problema só brasileiro, pois cada profissão, identificável como tal, tem também conteúdos, que constituem um saber específico e que a distingue das demais práticas profissionais. Mas, em nossa realidade, o problema da formação médica adquire uma conotação particular devido às peculiaridades ao mesmo tempo 'periféricas', 'continentais' e 'regionais' que, no Brasil, todos os problemas adquirem, o que torna muito difícil, senão impossivel, pensar em uma única realidade a qual propor e aplicar instrumentos de transformação homogêneos.

Do ponto de vista da ética aplicada ao campo da saúde do Brasil, isso implica ter de equacionar a difícil dialética entre a pretensão universalista dos princípios morais republicanos e seus conteúdos cognitivos aplicáveis a todos os cidadãos e o respeito das peculiaridades multiculturais de uma sociedade 'mestiça', como a brasileira, sem que isso redunde no relativismo moral que aparentemente respeita os valores de cada comunidade (de interesses e valores), mas que, de fato, pode redundar na legitimação, moralmente inaceitável, das disparidades e desigualdades regionais.

Em suma, nos ‘muitos Brasis' que compõem a nação brasileira real, a formação médica deve necessariamente enfrentar o desafio de pensar, simultaneamente, o universalismo das regras morais e o particularismo das diferenças, atuando com sensibilidade para com todos e cada um, fazendo com que o 'nós' seja inclusivo das diferenças legítimas, não das moralmente inaceitáveis. A meu ver, esta tensão percorre todo o texto do autor, como bem poderá verificar o leitor atento ao se deparar com a distinção entre a forma ou as estruturas do desenvolvimento moral e seus conteúdos concretos.

Um segundo mérito diz respeito ao rigor intelectual e metodológico com o qual Sérgio Rego aborda, pacientemente, esta problemática, pela análise críti- 
ca das teorias da socialização e, sobretudo, das várias teorias cognitivistas contemporâneas do desenvolvimento moral do indivíduo, que têm seus antecedentes na filosofia de Platão, para quem, quando um ser racional conhece o que é correto - o Bem -, não pode não agir corretamente, e de Kant, para quem a ação moral se baseia na vontade boa, conforme a razão, e só vale se é vivenciada como um dever universalizável, e sua reformulação experimental nas pesquisas de Piaget, Kohlberg, Gilligan, Rest, Self, Turiel e Lind, apresentadas detalhadamente pelo autor.

É importante ressaltar que o autor consegue apresentar todas essas informações em linguagem também compreensível e - acrescentaria - 'leve', no sentido consagrado pelo escritor tcheco Milan Kundera, para qualquer leitor inteligente que não esteja familiarizado com os arcanos dos idioletos especializados, traduzindo os conteúdos de tais teorias em ferramentas conceituais operacionais adaptadas ao desafio enfrentado.

Evidentemente, como em todo trabalho intelectual inovador, existem perguntas não respondidas e o autor sabe muito bem disso, deixando tal fato explícito nas considerações finais. Mas tais perguntas são imputáveis mais à teoria cognitivista adotada do que à própria performance do autor. Por exemplo, quando o cognitivismo moral fala em 'estágios morais', conceito introduzido por Piaget e desenvolvido por Kohlberg, para os quais existiria não só homologia entre saber epistêmico e saber moral, mas também um preciso amadurecimento moral conforme uma arquitetura em estágios, pode-se perguntar se a vida moral dos sujeitos morais não mereceria uma topologia mais sofisticada, capaz de dar conta de autênticas 'regressões' morais em determinadas situações-limite, nas quais os sujeitos morais estão impedidos de lançar mão de todos seus recursos cognitivos para enfrentar tais situações. Do ponto de vista da ética aplicada, essa questão é certamente relevante, pois diz respeito àquela que pode ser chamada a condição necessária de um ato moral, isto é, à competência para a análise racional e imparcial de um conflito moral, sem a qual o tipo de prescrição decorrente pode ser prejudicado por ser, de fato, parcial. Mas este é um aspecto da teoria cognitivista que pode ser esclarecido por pesquisas posteriores do próprio autor ou por quem, inspirando-se nele, se preocupar com este assunto.

Com isso, chegamos ao terceiro mérito principal do livro. Refiro-me à sua preocupação em propor uma solução para a inadequação atual da formação ética dos estudantes em medicina. Coerentemente com sua visão cognitivista, o autor propõe o que poderíamos chamar de ‘re-humanização' da prática médica 
por meio da educação bioética dos estudantes em medicina, que ele considera prima facie capaz de proteger não só os pacientes do encontro/desencontro clínico, mas também os profissionais de saúde em suas inter-relações e em suas relações com as instituições. Este mérito deve ser destacado, pois diz respeito ao sentido mais importante da bioética, ou seja, ao fato de esta não só servir para analisar imparcialmente e resolver normativamente conflitos entre agentes e pacientes morais, mas ainda, e, sobretudo, para proteger as pessoas, atores desses conflitos, em sua vulnerabilidade de seres finitos e mortais.

Em outras palavras, se considerarmos uma das razões pelas quais surge a bioética - a proteção dos indivíduos humanos, inscrita no Código de Nürenberg (1947) -, pode-se dizer que esta adquire historicamente o papel de proteger a 'vida nua', conforme a feliz expressão do filósofo italiano Giorgio Agamben, contra qualquer abuso de autoridade e de poder e de uns sobre os outros na era da instauração do biopoder e da biopolítica, exercidos, muitas vezes, em nome da cidadania e de uma suposta qualidade de vida para todos e para qualquer um, mas que, de fato, pode servir para perpetuar a distinção entre os seres humanos que são ‘cidadãos' de jure e de facto e aqueles que só o são de jure, mas não de facto.

Assim sendo, a bioética pode ser uma ferramenta indispensável também para profissionais que terão 'a vida dos outros nas mãos', e que, por isso mesmo, deverão fazer todo o possível para que os 'outros', que deles dependem - devido a uma assimetria de poder intrínseca à relação médico-paciente -, sejam não só 'tratados', mas, em primeiro lugar, 'reconhecidos' ao mesmo tempo em sua fragilidade e em sua dignidade e autonomia. De fato, sem este reconhecimento do outro não existe vida ética e, menos ainda, bioética, mas somente biopoder. Este, sem aquela, só pode se transformar em instrumento de sofrimento moralmente injustificado e é esta conclusão que o belo e importante livro do amigo e colega me inspira.

Fermin Roland Schramm

Pesquisador titular e coordenador do Núcleo de Ética Aplicada e Bioética da Escola Nacional de Saúde Pública da Fundação Oswaldo Cruz (Ensp/Fiocruz), presidente da Sociedade de Bioética do Estado do Rio de Janeiro (SBRio) e consultor de bioética do Instituto Nacional do Câncer (Inca) 


\section{Apresentação}

Se este livro é, por um lado, o resultado direto de minha tese de doutorado, defendida no Instituto de Medicina Social da Universidade do Estado do Rio de Janeiro (Uerj), por outro, ele revela algumas das preocupações que me acompanham desde que ingressei na Faculdade de Medicina da Universidade do Rio de Janeiro (UNI-Rio) e comecei a conviver com pacientes, professores, médicos, enfermeiras e demais membros da equipe de saúde. Dentre as preocupações, estão a qualidade do atendimento oferecido e das relações que são estabelecidas entre os membros desta comunidade dedicada a um dos momentos mais difíceis na vida de qualquer pessoa, quando a própria existência está ameaçada pelo que se convencionou chamar de enfermidade.

Não tenho a menor dúvida em afirmar que a maioria das faculdades de medicina, tal como são organizadas e buscam cumprir a função primordial que justifica a sua existência - preparar jovens para o exercício da profissão médica -, é incompetente.

Da mesma forma, peremptória, afirmo que, em qualquer lugar do mundo, a incompetência da maioria das escolas é semelhante. Se no campo do desenvolvimento das habilidades técnicas ou da competência técnica existem várias escolas no mundo que têm uma atuação satisfatória, no desenvolvimento das competências, digamos relacionais, como as de comunicação e éticas, elas deixam muito a desejar.

Esta minha comunicação pode ser ilustrada pela seguinte fábula:

Há muitos e muitos anos, uma determinada comunidade sobrevivia da caça de tigres dente-de-sabre. Este era o seu principal alimento e sua caça era uma questão de sobrevivência da comunidade. Poucas, entretanto, eram as pessoas capazes de caçá-los, pela técnica especifica requerida. Com o intuito de multiplicar o número de pessoas aptas a caçá-los, criou-se uma escola para formar caçadores de tigres dente-de-sabre. $O$ sucesso da escola 
foi tamanho que em algum tempo já não havia mais tigres dente-de-sabre. Logo, a comunidade passou a caçar outros animais e desenvolveu a agricultura para assegurar sua sobrevivência. A escola? Bem, a escola continuou a ensinar a caçar os tigres.

Mesmo hoje, quando muitas escolas experimentam novas abordagens pedagógicas, incentivando a capacidade de pensamento crítico e autônomo por parte dos alunos e não meramente entendendo-o como um receptáculo acrítico de informações, característica do chamado ensino bancário tradicional, quando considero a questão da competência moral, vejo que a maioria das escolas ainda patina na compreensão de que o indivíduo é uma tábula rasa, na qual os valores vão sendo escritos ou que tão-somente o exemplo é suficiente para moldar o caráter dos futuros médicos.

Se a educação não pode permanecer nas mãos de profissionais ignorantes em pedagogia, ainda que bons técnicos, muito menos pode ser relegada à educação moral. Não é possível que se continue deixando a tarefa de preparar os futuros profissionais nas mãos daqueles que entendem ser suficiente a apresentação de um Código de Ética ou de meia dúzia de soluções pré-fabricadas para conflitos éticos aos alunos para se formar profissionais competentes desse ponto de vista. Não se pode continuar a ensinar ética deixando os alunos como se estivessem assistindo a um filme de televisão. Mais do que nunca é preciso deixá-los pensar, debatendo criticamente a realidade com a qual eles convivem e preparando-se para atuar em sua vida profissional de forma autônoma e 'dialogadora', respeitando o outro e suas próprias visões de mundo e os direitos humanos. A escola médica tem esse papel e pode exercê-lo, como procurei discutir aqui.

Apesar de o enfoque deste livro ser a formação médica, quase todas as reflexões realizadas aplicam-se, com as devidas adaptações, às competências específicas e aos demais processos de formação profissional na área da saúde. Os leitores interessados em outros processos de formação não terão grandes dificuldades em realizar, eles próprios, o salto reflexivo para esses outros processos educacionais. Há muito, a medicina é tomada, explicitamente ou não, como modelo para as outras profissões. Muitos dos erros cometidos no ensino médico também se reproduziram na formação de outros profissionais e eu espero que esse livro seja um estímulo aos pensadores que se dedicam à reflexão desses outros processos de formação a ampliarem os seus próprios estudos nesta direção. 
É preciso formar nossos jovens não apenas para viver no seu tempo e enfrentar os desafios que ele apresenta. É necessário desenvolver sua capacidade de pensarem criticamente e de mudarem, se não o mundo, pelo menos o seu mundo, como escreveu Brecht, no poema apresentado como epígrafe deste livro.

A medicina é uma profissão que traz, implicitamente, a expectativa de um comportamento pleno de virtudes por parte de seus profissionais. Admitese, todavia, que alguns possam, em determinadas situações, falhar. A representação social do médico é, entretanto, a de alguém virtuoso, realmente preocupado com o bem-estar dos outros e que optou por dedicar sua vida à salvação das pessoas. Mas, há algum tempo, esta imagem vem sendo arranhada.

Como mostrarei nos diversos capítulos deste livro, já existe uma ampla literatura tematizando a preocupação entre acadêmicos, estudantes, e a população em geral, com a chamada humanização da medicina ou sua falta. Sente-se que o médico perdeu algo, talvez um pouco de sua empatia para com os seus pacientes, talvez a imagem de 'bom samaritano'...

Mas, terá perdido mesmo? Será que essas queixas não são fruto, por exemplo, de um certo saudosismo de um tempo em que o médico visitava seus poucos pacientes de casa em casa, ouvindo cada um, tratando seus males físicos e dando conselhos? Será que esta saudade não é a saudade de um tempo idealizado, conhecido pela maioria a partir apenas dos relatos ufanistas que os próprios médicos fazem? Não será possível que esteja sendo esperado um comportamento que, nos dias de uma medicina altamente dependente de tecnologias e onde o local de sua prática, por excelência, passou a ser o hospital, é não somente improvável como praticamente impossível? Ou seja, será que toda essa crítica não passa de uma certa nostalgia dos tempos em que a vida era mais fácil, os carros andavam mais devagar, os médicos não eram tantos e os pacientes eram sempre únicos? Além disso, será que ainda é possível pensar nos médicos que atendem a um mínimo de 12 pacientes nos serviços públicos em uma jornada de 4 horas darem a seus pacientes outro tipo de atenção? Será que 20 minutos ${ }^{1}$ por paciente é suficiente para dar a atenção devida? Será que tudo é uma questão de tempo? Sendo pouco 20 minutos, se fossem 45 minutos, os médicos dariam a atenção devida a cada um de seus pacientes? Será que o

Sabe-se que os 20 minutos 'padrões' são irreais. Na maioria das vezes, nas grandes unidades públicas de pacientes externos, o tempo dedicado a cada paciente nem se aproxima do padronizado e por motivos que não são, necessariamente, os mais nobres. 
problema é que no serviço público os médicos têm a obrigação de atender a um grande número de pacientes e, nos consultórios, onde foram 'escolhidos', o atendimento é diferente? Será que a distinção entre 'tipos' de pacientes é uma prática comum? Existirão os que 'valham' mais ou aqueles para os quais, por circunstâncias de atendimento, o médico acaba dando mais atenção? Será um problema de mercado ou de formação? Tantas perguntas, tantas hipóteses...

Para iniciarmos nossa busca por respostas, apresentaremos um caso real como exemplo.

Trata-se de um paciente de 78 anos necessitando de troca de gerador do marcapasso cardíaco. Combina a cirurgia com o médico conveniado (dr. XX) com seu plano de saúde, mas metade dos custos da cirurgia será paga diretamente ao médico, por acordo, assim como o da internação, já que o médico não aceita as alternativas, na mesma clínica, que o plano de saúde oferecia. A troca terá de ser feita no Centro Cirúrgico, e não na Hemodinâmica, como da primeira vez com outro médico, e a estadia será na UTI, e não em quarto particular, coberto pelo Plano, como da primeira vez.

Dia da cirurgia. $O$ médico solicitara ao paciente que comparecesse às $7 h 30$ min. da manhã para a internação. A cirurgia começaria às 8 h30min. $O$ paciente compareceu no horário, o médico não. Internado às 9 h30min., o paciente foi levado para a sala de cirurgia às 10h. Lá, foi informado pela enfermeira que o seu médico não estava na clínica e que a cirurgia seria feita por um membro da equipe dele. Este entrou na sala de cirurgia e começou a se preparar. Entraram dois técnicos especializados em marcapasso, que passaram todo o tempo conversando ao telefone celular. Entrou a médica assistente. $O$ médico preparava-se para injetar o anestésico e, pela primeira vez, dirigiu-se ao paciente:

- $O$ sr. é o senhor fulano, não?

Não o cumprimentou, não justificou seu atraso, não justificou a ausência do 'titular', com quem fora combinada a cirurgia. Avisou que ia dar uma agulhada e prosseguiu. Solicitou ao paciente que reclamasse se doesse. De tempos em tempos, o médico substituto do titular dirigia alguma pergunta ao paciente, possivelmente com o objetivo de verificar seu estado de consciência. Finda a cirurgia, não se despediu, não lhe deu informação apenas se retirou da sala. Os demais presentes já haviam se retirado.

No leito da UTI, o paciente foi 'visitado' diversas vezes pelos médicos de plantão, e pelo seu médico, uma vez. Nenhum deles chegou a 'olhar para baixo', como ele declarou. Entravam no quarto, verificavam o monitor cardíaco e se retiravam avisando que estava tudo bem. $O$ paciente reclamava: 'Eles nem entrariam no meu quarto se houvesse um terminal com o meu monitor na sala deles!'. 
Machado (1996) discutiu essa deterioração na relação médico-paciente e apontou o atendimento de qualidade diferenciada realizada pelos mesmos médicos, dependendo do local onde eles estivessem: no hospital público ou em seu consultório privado. A autora também havia indicado a distinção que era praticada, nesses atendimentos, entre pacientes conveniados e os chamados "particulares'. E qual o porquê de eu fazer essas referências e contar esse caso?

Porque entendo que é importante que seja destacado que essas questões não se limitam aos aspectos relacionados tão-somente ao mercado de trabalho e sua organização, embora seja possível encontrar explicações também neste campo. Se, como Machado afirmava, a distinção entre pacientes era mais significativa entre os 'públicos' e os 'privados', nos dias de hoje, relatos como o que aqui fiz se multiplicam e podem ser ouvidos sem dificuldade sempre que se introduz esse tema na maioria dos ambientes.

Vejamos, como mais um exemplo, que Kloetzel (1999), em seu livro sobre medicina ambulatorial, sentiu a necessidade de alertar seus leitores que, quando ele faz referência ao 'ambulatório', não distingue o consultório privado de um centro ou posto de saúde, as dependências de um seguro-saúde ou de um convênio. E essa ressalva é feita exatamente no capítulo inteiramente dedicado ao paciente.

Esse autor, apropriadamente, assinala que

em todas essas situações as características da demanda são as mesmas, assim como são idênticos os objetivos e os obstáculos - à exceção, é natural, da questão do custeio dos cuidados de saúde. (De resto, qualquer que seja o local deste primeiro encontro entre médico e paciente, é sempre possível praticar uma 'boa medicina'- desde que, claro, o profissional realmente esteja empenhado a fazê-lo.). (Kloetzel, 1999: 51)

Entendo que o estudo criterioso e sistemático da formação profissional é um dos caminhos preferenciais para que se possa entender melhor essa situação e analisar os melhores caminhos e estratégias que podem ser estabelecidos para estimular e promover mudanças. Mas, particularmente em nosso país, a experiência acumulada com estudos sobre o tema ainda deixa muito a desejar. Não só são inúmeros os temas, métodos e referenciais teóricos que são pouco explorados, como ainda temos poucos profissionais dedicados efetivamente a esse estudo. Quando volto minha atenção especificamente ao campo da formação moral dos médicos, buscando o que determina ou contribui para que 
estes pensem, ajam e reajam de determinada maneira ou com determinado padrão de atitudes, os estudos no Brasil mostram-se praticamente inexistentes.

Inserido neste amplo movimento que busca repensar a educação médica no Brasil, que tem suas origens na década de 70 do século passado e chega até os dias de hoje com o projeto de avaliação das escolas médicas, coordenado pela Associação Brasileira de Educação Médica (Abem), com as iniciativas de avaliação do ensino superior do Ministério da Educação, as experiências transformadoras do ensino médico de faculdades, como as de Londrina e Marília, as Novas Diretrizes Curriculares e o Programa de Incentivo à Mudanças Curriculares, busco respostas a algumas dessas questões relacionadas à formação moral dos estudantes de medicina.

Não escrevo este livro apenas para a leitura dos especialistas no tema. Procuro sintetizar neste um conjunto de informações que possibilitasse a professores de medicina, alunos dos cursos e estudiosos do campo da educação médica e da ética um entendimento amplo da situação.

Inicio a abordagem com um breve histórico da educação médica e uma síntese de alguns dos modelos de ensino que vêm firmando-se (ou que já se firmaram) como os mais significativos no panorama nacional.

Nos segundo e terceiro capítulos, busco apresentar um panorama crítico dos diferentes referenciais teóricos que visam a explicar como se dão a socialização profissional e a conformação da moral do indivíduo. Entendo que é possível extrairmos fundamentos explicativos consistentes de todos eles, não nos afiliando, de forma ortodoxa, a nenhum deles, embora tenhamos optado claramente por considerar a perspectiva cognitivista como a base fundamental de nossas análises.

No quarto capítulo, apresento os resultados de nossa pesquisa, realizada com estudantes de diversas escolas médicas do país, na qual busquei compreender o que os estudantes entendem por 'ser ético na prática profissional' e, em última instância, 'o que fazer para ser ético'. Sigo perguntando a eles se, em algum momento de seu processo de formação, já haviam vivenciado alguma situação em que entendiam que uma questão ética estava em jogo e, naturalmente, o que aconteceu. A partir dessas respostas, procurei também entender de que forma as ações educativas da faculdade colaboram com os estudantes para lidarem com estas situações que eles descreveram. 
Assim, logrei realizar não apenas um diagnóstico situacional, mas também nos foi possivel estabelecer hipóteses explicativas para a situação, entre as quais se destaca a de que no processo de formação ocorre um fenômeno que chamei de 'coisificação do ser humano', no caso os pacientes, como um resultado da reificação do paciente como objeto.

No sétimo capítulo, apresento uma reflexão crítica sobre os caminhos que algumas faculdades do exterior vêm percorrendo no enfrentamento dessa questão, defendendo, por fim, o ensino da ética aplicada e da bioética no contexto do ensino das humanidades médicas de forma integrada, apontando-se, dessa forma para um futuro, a perspectiva do ensino verdadeiramente transversal, aliado a uma integração das atividades de extensão universitária a este contexto.

Enfim, espero, com este livro, estar contribuindo para que outros se aventurem pelo mesmo campo de investigação e que possa colaborar com o necessário, mas difícil, processo de mudança de nossa sociedade.

Preciso, finalmente, dar uma espécie de alerta final, imprescindível em se tratando do tema, sobre a abordagem aqui realizada. Em nosso país, a discussão sobre educação moral esteve em pauta como uma ação do Estado autoritário, com as disciplinas de moral e cívica e estudos dos problemas brasileiros, quando, de fato, tratava-se de uma tentativa de reforçar um comportamento heterônomo. Não é este o meu ponto de vista: entendo que o objetivo principal da educação moral seja o de favorecer o desenvolvimento em busca da capacidade de julgar e decidir autonomamente, ou seja, da competência moral.

Da mesma forma, o tema é freqüentemente abordado com uma perspectiva religiosa, confundindo-se educação moral com educação religiosa. Minha perspectiva aqui é laica. Embora reconheça o papel da educação religiosa na educação moral, entendo que em uma sociedade democrática e plural a única perspectiva educacional defensável para toda a sociedade é a do ensino laico, sem prejuizo de qualquer opção religiosa que os indivíduos e/ou suas famílias façam em qualquer momento de suas vidas.

Inúmeras pessoas contribuíram, direta ou indiretamente, na realização deste trabalho. Citá-las todas seria não apenas complicado, em termos de espaço, como arriscado, pelas inevitáveis omissões involuntárias. Agradeço, portanto, a todos com quem tenho convivido e partilhado reflexões tanto na Escola 
Nacional de Saúde Pública da Fiocruz (Ensp/Fiocruz), no lnstituto de Medicina Social da Uerj (IMS/Uerj), na Associação Brasileira de Educação Médica (Abem), nas Sociedades Brasileira e do Estado do Rio de Janeiro de Bioética (SBB e SBRio) e na Comissão de Bioética do Conselho Regional de Medicinal do Estado do Rio de Janeiro.

Não poderia deixar de dedicar ao menos uma frase exclusiva aos estudantes de medicina com os quais tenho tido o privilégio de conviver e aprender muito sobre sua visão de mundo, aspirações e perspectivas críticas, seja na Abem, seja na Direção Executiva Nacional dos Estudantes de Medicina (Denem) e, principalmente, àqueles que dedicaram generosamente uma parte de seu tempo e de sua paciência para participarem de minha pesquisa.

Alguns nomes serão aqui ressaltados pela relação direta e intensa com este trabalho, e por partilharmos mais do que fundamentos teóricos - partilhamos a inquietação e o inconformismo com o desrespeito pelo ser humano.

Clary Milnitsky Sapiro, professora da Universidade Federal do Rio Grande do Sul (UFRGS), pessoa de generosidade intelectual rara nos meios acadêmicos a quem eu devo o entendimento das teorias de desenvolvimento moral e minha aproximação definitiva a este referencial teórico; Fermin Roland Schramm, pesquisador da Escola Nacional de Saúde Pública da Fundação Oswaldo Cruz (Ensp/Fiocruz), presidente da SBRio, orientador de minha tese e parceiro no quotidiano de reflexões sobre as éticas aplicadas à saúde e nas ações pela difusão dessas reflexões para a sociedade, é um modelo inspirador para mim como professor e pensador, além de ser um dos mais influentes, criativos e consistentes bioeticistas no Brasil; Jane Dutra Sayd, professora do Instituto de Medicina Social da Uerj (IMS/Uerj), amiga de longa data, orientadora de minha tese e interlocutora, cada vez mais freqüente nas discussões sobre a Educação Médica; e Marisa Palácios, professora do Núcleo de Estudos em Saúde Coletiva (Nesc) da Universidade Federal do Rio de Janeiro (UFRJ), companheira freqüente e instigante, tanto por seu convívio direto com estudantes de medicina quanto por seu olhar peculiar, resultado de sua sólida formação acadêmica.

Tenho a certeza de que você, leitor, encontrará, neste livro, fundamentos teóricos e empíricos para a sua reflexão teórica e para a sua ação concreta. 


\section{1 \\ Educação Médica: história e questões}

“A pobreza da educação médica latino-americana não é só de recursos, é também de idéias” (Carlos Martini, 1990: 152).

Neste capítulo, ${ }^{2}$ apresentaremos um breve histórico da constituição do sistema educacional brasileiro, buscando identificar as matrizes que inspiraram ou orientaram a constituição de nossas escolas médicas.

As escolas médicas encontram-se há mais de cinqüenta anos sob recorrente crítica em todo o mundo e, em particular, na América Latina. ${ }^{3}$ Ao final, discutiremos de forma sucinta o que chamaremos de possiveis tendências para o redirecionamento da educação médica no Brasil e no mundo: a medicina baseada em evidências e a aprendizagem baseada em problemas. Dessa forma, situaremos o leitor no universo teórico-prático da educação médica, possibilitando um melhor entendimento das discussões específicas sobre a formação moral do estudante de medicina, que constituem o foco deste livro.

“A medicina é um sacerdócio!”. Quem ainda não ouviu uma afirmação com este teor? De fato, existe um senso comum de que a medicina pode e deve ser comparada ao sacerdócio por estar associada à idéia de uma vida altruística e dedicada, 24 horas por dia, a servir ao próximo necessitado. Com efeito, as grandes religiões monoteístas, dentre elas a judia, a cristã e a muçulmana, influenciaram de forma decisiva a construção do ethos profissional médico, sendo a separação entre religião e medicina uma exigência que só aparece com o surgimento das cosmovisões com base nas interpretações e compreensões científicas e técnicas da realidade. Esta é a concepção laica e secular da prática médica, que somente

Este capítulo é uma versão substancialmente ampliada do texto "Educação médica e a formação ética dos estudantes de Medicina”, elaborado em co-autoria com Schramm e Fermin Roland, publicado no CD-Pesquisa de 2000 da Enciclopédia Britânica, Rio de Janeiro.

Para uma visão geral das críticas sobre a educação médica nas Américas, ver Chaves (1990), e para informações mais detalhadas sobre o histórico de crises na educação médica e os movimentos de reforma, ver Almeida (1999). 
surge no Ocidente a partir da ldade Moderna e que, na verdade, ainda não parece ser aceita por todos os profissionais.

Historicamente, o objeto de trabalho do 'médico' modificou-se substancialmente. Para as chamadas 'sociedades primitivas', ${ }^{4}$ por exemplo, a doença era provocada por uma ação externa ao indivíduo, de tipo espiritual, e a função terapêutica ('médica') era exercida pelo pajé ou xamã, cujo papel era de expulsar os maus espíritos do corpo do enfermo e assim obter a cura do doente, intervindo diretamente sobre as forças espirituais. ${ }^{5}$

A tradição judaico-cristã, por sua vez, concebia o mal - seja como possessão demoníaca, seja como castigo divino - uma decorrência direta dos pecados supostamente cometidos pelo enfermo. 0 papel do sacerdote (ainda que exercendo a função de 'médico') era o de obter a salvação espiritual do enfermo, através de sua intermediação com o ser divino. Scliar apresenta inúmeros exemplos extraídos do Antigo Testamento demonstrando a relação entre a doença e o castigo divino - "se não me escutardes e não puserdes em prática todos estes mandamentos, se desprezardes as minhas leis (...) porei sobre vós o terror, a tísica e a febre..." (Levítico, 26:16 apud Scliar, 2001: 20) -, embora assinale também que quando isso ocorre o castigo é bem visível, em geral atingindo a pele e implicando a segregação do pecador.

0 cristianismo, por sua vez, não somente manteve a concepção da enfermidade como punição aos pecadores como também incorporou a tradição da segregação dos leprosos e depois dos loucos (ambos identificados como impuros). Assim, até o final da ldade Média, a ação fundamental dos médicos, sacerdotes em sua maioria, era a de salvar almas e, apenas secundariamente, possibilitar a sobrevida dos enfermos (ainda que esta fosse uma ação secundária importante em seu papel). Tanto que os hospitais europeus eram, em sua maioria, vinculados a ordens religiosas, cujo objetivo fundamental era salvar as almas dos doentes e, subsidiariamente, oferecer aos pacientes que não possuiam família ou que precisavam ser excluídos do convívio social um local digno para morrer.

A expressão ‘sociedades primitivas' identifica aquelas sociedades em que o desenvolvimento da produção ainda não viabilizara a acumulação e a apropriação de um excedente econômico suficiente para dar início à divisão social do trabalho (Gonçalves, 1987).

5 Scliar (2001) identifica apenas um modelo 'mágico-religioso', no qual reúne tanto a feitiçaria como a religiosidade da tradição judaico-cristã. Entendemos que a distinção é necessária, pois no primeiro o entendimento do processo saúde-doença tende a identificar o enfermo como vítima, enquanto no segundo atribui-se alguma 'culpa' ao sujeito, já que está relacionado com atos ou pensamentos impuros. 
Apenas no século XVIII o papel do hospital foi alterado, tendo sido destinado efetivamente à cura física dos enfermos. Foucault aponta que as transformações que deram origem ao hospital com fins terapêuticos estão associadas às políticas de expansão comercial e de fortificação do poderio militar, peculiares ao Estado absolutista e ao mercantilismo:

Se os hospitais militares e marítimos tornaram-se o modelo, o ponto de partida da reorganização hospitalar, é porque as regulamentações econômicas tornaram-se mais rigorosas no mercantilismo, como também porque o preço dos homens tornou-se cada vez mais elevado. É nesta época que a formação do indivíduo, sua capacidade, suas aptidões passam a ter um preço para a sociedade. (Foucault, 1988: 106)

Como não poderia deixar de ser, também no Brasil esta era a realidade, alterada apenas em meados do século XIX com a criação das primeiras Casas de Saúde (em alternativa aos hospitais - considerados a antecâmara da morte) ${ }^{6} \mathrm{e}$ finalmente com a reforma da Santa Casa da Misericórdia no final daquele século.

Até que o processo chamado "medicalização"7 ocorresse, não havia médicos diariamente nos hospitais e apenas os serviços religiosos eram oferecidos diariamente (em especial a confissão, obrigatória para todos os que se internassem) ${ }^{8}$.

Ainda no início do século XX, pode-se constatar a forte repulsa popular à idéia de hospital, com o episódio que cercou a criação do serviço de ambulâncias do primeiro pronto-socorro da então capital, o Rio de Janeiro, e que ninguém ousava utilizar, tendo sido necessário que a administração do mesmo contratasse atores que simulassem uma enfermidade na rua (Junqueira, 1966). Assim, após o 'atendimento satisfatório' aos atores e sua 'cura', a população começou a adquirir confiança no serviço.

A seguir, veremos brevemente um pouco do modelo de ensino médico adotado no Brasil após a vinda da família real portuguesa.

Para um melhor entendimento sobre o papel das casas de saúde no processo de medicalização dos hospitais no Brasil, ver Rego (1993).

Entendendo-se por processo de medicalização do hospital as transformações que ocorreram na forma de organização hospitalar e que levaram a assumir o ato terapêutico com um papel fundamental dentro das atividades hospitalares, de acordo com Foucault (1988).

$8 \quad 0$ estatuto de 1776 do Hospital dos Lázaros, por exemplo, previa a existência de "um médico para fazer duas visitas por semana e um cirurgião para assisti-los continuamente" e a obrigação de ter "um capelão que deve assistir dentro dêle, para acudir mais prontamente com os socorros espirituais aos miseráveis enfermos, e nenhum dêstes será recolhido ao hospital, sem que primeiro, por informações do Rev. Capelão, conste haver ele se confessado" (apud Araújo, 1982: 49). 


\section{O Ensino Médico no Brasil: origens}

Tradicionalmente, utiliza-se como marco histórico do ensino médico no Brasil a criação do primeiro curso médico, em 1808, na Bahia, logo após a chegada da família imperial. Tal fato, entretanto, não significa que antes desse momento não houvesse médicos ou mesmo um sistema de formação de médicos no país.

Segundo Santos Filho (1977), os primeiros médicos que vieram ao Brasil foram formados na Universidade de Coimbra. ${ }^{9} 0$ ensino de medicina nessa Universidade, até o final do século XV, era feito por apenas um lente, ${ }^{10}$ quando foi introduzida uma nova cadeira e o número de docentes passou a dois. A partir desse período, os alunos tinham a leitura das obras de Galeno (pela manhã) e as de Hipócrates (à tarde). Remonta a este tempo o nome atribuído aos médicos como 'físicos', uma vez que a medicina era chamada de 'física' "ciência que indagava, pela observação e pela experiência, dos corpos naturais" (Santos Filho, 1977: 277).

Até o século XV, o ensino da medicina era atribuição dos religiosos e a eles destinado em sua maioria, mas, a partir de então, leigos (em especial os de origem judaica), passaram a ser a maioria. Apenas em 1540 foi introduzida a leitura de autores árabes (Avicena, Rhazes e Averróis - comentadores de Hipócrates e Galeno). Durante toda a ldade Média,

\footnotetext{
a cirurgia foi relegada a plano inferior e abominada por princípios religiosos.

Olvidaram-se os mais elementares preceitos de higiene, sobrevindo, então, as pavorosas epidemias que assolaram toda a Europa. Um terrivel fanatismo religioso dominou os espíritos. (Santos Filho, 1977: 280)
}

Santos Filho refere-se ao período em que a Santa Inquisição foi estabelecida em Portugal. Ele, entretanto, não apresenta as razões religiosas que 'abominavam a cirurgia'. De fato, a cirurgia sempre foi considerada inferior por ser um trabalho manual, em contraste com o trabalho intelectual dos físicos, e tinha ainda menos resultados positivos que a medicina clínica (estamos nos referindo ao período anterior ao descobrimento e utilização de anestésicos e da importância da assepsia), mas não encontramos indícios históricos que fundamentassem de forma detalhada esta afirmação do autor. Tanto que a

A Universidade de Coimbra foi criada em 1290 e, em seus primórdios, alternou sua localização entre Lisboa e Coimbra. 0 retorno definitivo para esta cidade deu-se em 1537.

10 Os professores eram chamados de lentes porque apenas 'liam' os textos. Até 1493, existia apenas um lente para o curso médico. 
primeira autoridade designada para fiscalizar o exercício das artes médicas e cirúrgicas foi um cirurgião-mor dos exércitos, em 1260, sendo um físico-mor designado apenas em 1430, conquistando autonomia e hegemonia em 1521 (Machado et al., 1978). Possivelmente, a afirmação do autor está relacionada com a posição contrária à abertura de corpos. É fato reconhecido que a maioria das religiões vedava, efetivamente, a violação de cadáveres (Foucault, 1987).

Note-se, portanto, que apesar de a medicina praticada ser a hipocrática, baseada na observação, experimentação e negando as influências metafísicas, até o século $\mathrm{XV}$, quem a ensinava eram, em sua maioria, membros do clero, sendo a estes igualmente destinados o ensino.

Apenas em 1562 foi introduzida a prática hospitalar, modificando-se, assim, o modelo de ensino baseado apenas na leitura de textos. Mas tal introdução não significou a adoção de um modelo de ensino com base em atividades hospitalares práticas, semelhante ao atual. Representou, de fato, apenas o abandono da tradição do mero ensino oral, sem qualquer tipo de atividade prática.

A despeito das grandes descobertas advindas da invenção do microscópio no século XVIl, que impulsionavam o desenvolvimento da observação científica em grande número de escolas médicas européias, as escolas portuguesas e as castelhanas estavam fechadas a este tipo de prática. Assim, os primeiros médicos que vieram para o Brasil possuíam um perfil formado na Universidade de Coimbra, fortemente influenciada pelo obscurantismo religioso que imperava na Península lbérica da Inquisição. Este modelo de ensino permaneceu inalterado, em sua essência, até a Reforma"1 empreendida pelo Marquês de Pombal em 1772. Considerando-se todo o aparelho escolar, do nível elementar ao superior, em Portugal, até a época do Marquês de Pombal, e no Brasil, até a vinda da corte, o ensino público era estatal e religioso. Não só era religiosa a instituição que formava os professores (em geral, sacerdotes) como também era a lgreja Católica que administrava as escolas.

Em fins do século XVIII, profundas transformações políticas, econômicas e culturais ocorreram em Portugal, que se repercutiram, como não podia deixar de acontecer, em suas colônias, entre elas o Brasil. Tendo como meta o estímulo ao desenvolvimento do capitalismo em Portugal, buscava-se criar condições que propiciassem a acumulação de capital estatal e privado. Nesse sentido, a

Para maiores informações sobre as repercussões da Reforma pombalina nas Universidades, ver Cunha (1986). 
atuação dos jesuítas no Brasil era contrária aos interesses de Portugal, visto que se opunham à escravização dos índios, recusavam-se a lhes ensinar o idioma português (que possibilitaria uma melhor utilização deles no mercado de trabalho, ainda que com remuneração extremamente baixa), mantinham intenso comércio sem que se sujeitassem às normas e aos impostos ditados pelo rei e, por fim, defendiam o feudalismo. Os jesuitas negavam-se a reconhecer a autoridade do papa, submetendo-se apenas ao líder da Ordem.

Foi nesse período que a Companhia de Jesus - principal responsável pelo ensino secundário e superior, na metrópole e na colônia - foi expulsa do império português, acarretando grandes transformações no panorama escolar. A expulsão dos jesuítas não correspondeu à hegemonia de nenhuma outra ordem religiosa (...) mas, sobretudo, deu lugar a novos currículos, novos métodos de ensino, nova estrutura da educação escolar. (Cunha, 1986: 38)

A despeito de ter entrado para a História como o responsável pela expulsão da Companhia de Jesus de Portugal e de suas colônias, o comportamento do Marquês de Pombal não deve ser entendido como anticlerical ou mesmo antireligioso. Mas, embora a Reforma Pombalina não tenha se caracterizado como anticlerical, o simples afastamento dos jesuitas do aparelho escolar possibilitou que elementos seculares fossem introduzidos no sistema, mesmo que isso não tenha representado o banimento dos aspectos religiosos do ensino, como veremos mais adiante falando do período do Império no Brasil.

Entre as novas exigências surgidas com a reforma do currículo médico após a intervenção pombalina no sistema educacional estavam aquelas feitas ao candidato no ingresso na escola médica: o conhecimento prévio do grego, da filosofia e o domínio de pelo menos uma língua estrangeira (inglês ou francês):

Cursaria, então, as matérias das faculdades de Filosofia e Matemática, matriculando-se, após os exames, no curso médico, composto de cinco cadeiras, uma em cada ano: matéria médica e farmácia, no primeiro; anatomia, prática das operações e arte obstétrica, no segundo; instituições (teoria médica) com a prática da medicina e da cirurgia no hospital, no terceiro; aforismos (de Hipócrates e Galeno), continuando com a prática no hospital, no quarto ano; prática da medicina e da cirurgia, novamente no hospital, no quinto e último ano, findo o qual submetia-se a exame perante todos os lentes, recebendo, se aprovado, o grau de "bacharel em Medicina e cirurgia. (Santos Filho, 1977: 291) 
Para a obtenção do título de 'licenciado', era necessário repetir, por mais um ano, as cadeiras de instituições e aforismos, e, para o de doutor, a defesa da tese.

Além da formação regular de médicos e cirurgiões nas universidades européias, havia, nos tempos coloniais, no Brasil, um sistema que permitia que indivíduos fossem 'licenciados' para a prática médica e de cirurgião-barbeiro, sem que tivessem freqüentado qualquer estabelecimento de ensino superior. Assim, médicos e cirurgiões regularmente formados podiam dispor de aprendizes que, ao contrário da formação acadêmica de forte conteúdo teórico, eram submetidos a treinamento empírico e deviam, após serem considerados aptos pelos tutores, prestar exames perante a Junta do Protomedicato e depois do Físico-Mor e do Cirurgião-Mor, as instâncias administrativas máximas no Brasil na área da saúde até meados do século XIX, designadas pelo rei de Portugal. Tal sistema, entretanto, prestava-se mais à compra das licenças do que a um tipo específico de aferição dos conhecimentos. Muito mais utilizado por aprendizes de cirurgia, era freqüente que escravos ou ex-escravos que ajudavam os seus 'senhores' em seu trabalho, acabassem adquirindo sua licença e se pusessem a concorrer com seus antigos senhores pela clientela.

Somente após a vinda da família real portuguesa para nosso país, fugindo da invasão napoleônica, foram criados os primeiros cursos regulares de medicina, inicialmente sob a forma de cadeiras, em Salvador, e, em seguida, no Rio de Janeiro. Ambos os cursos iniciaram-se em dependências militares (hospitais) que, outrora, pertenciam aos jesuítas. A criação desses cursos fazia parte de uma política real indispensável para a formação de futuros ocupantes de postos na burocracia estatal, ${ }^{12}$ que supririam as necessidades do recém-instalado governo português no Brasil.

Os currículos dos cursos médicos sofreram suas principais alterações em 1813 (quando ainda eram ministrados pela Academia de Medicina e Cirurgia do Rio de Janeiro e os cursos médico e cirúrgico eram separados e com cinco anos de duração cada) e em 1884, quando os cursos foram unificados e sua duração estendida para oito anos.

Os currículos desses cursos consistiam em:

Curso de ciências médicas e cirúrgicas

$1^{\circ}$ ano: física médica, química mineral e mineralogia médicas, botânica e zoologia médicas;

A fuga da família real para o Brasil demandou a criação de Academias Militares e outros cursos de nível superior na colônia, de forma a tornar viável a manutenção do centro de poder português em território além-mar. 
$2^{\underline{0}}$ ano: anatomia descritiva, histologia teórica e prática, química orgânica e biológica;

3ํano: fisiologia teórica e experimental; anatomia e fisiologia patológicas, patologia geral;

4ํano: patologia médica, patologia cirúrgica, matéria médica e terapêutica, especialmente brasileira;

5 ano: obstetrícia, anatomia cirúrgica, medicina operatória e aparelhos, farmacologia e arte de formular;

6 ano: higiene e história da medicina, medicina legal e toxicologia;

7o ano: clínica médica de adultos, clínica cirúrgica de adultos, clínica obstetrícia e ginecológica;

8o ano: clínica médica e cirúrgica de crianças, clínica oftalmológica, clínica de moléstias cutâneas e sifilíticas, clínica psiquiátrica. (Cunha, 1986: 102-103)

Ainda que os cursos não tivessem as mesmas características de antes da Reforma Pombalina e que a assimilação das descobertas e invenções européias não tivessem mais nenhum tipo de restrição - ao contrário, eram apreciadas - ,

não se deve pensar que o ensino nas escolas do Estado, no Império, fosse secularizado. A religião católica era, pela Constituição, religião de Estado. Por isso, os funcionários governamentais, entre eles os professores, tinham de prestar juramento de fé católica, podendo ser punidos por perjúrio; os estatutos das faculdades proibiam a professores e alunos ofensas à religião oficial; os doutorandos de medicina, particularmente, estavam proibidos de apresentar teses que contivessem princípios ofensivos à religião e à moral que ela legitimava; na base de todo esse aparato coercitivo, o código criminal proibia o ateísmo e a descrença na imortalidade da alma. (Cunha, 1986: 86)

Assim, se por um lado não havia restrição ao exercício profissional àqueles que professassem religião distinta da oficial; por outro, a moral que norteava sua prática devia ser a cristã. Esse constrangimento legal, além de determinar a participação historicamente demonstrada de sacerdotes como médicos e docentes em cursos médicos, determinou também a incorporação dos valores cristãos à moral profissional médica. Embora os currículos das faculdades de medicina não possuíssem ainda uma disciplina passível de equiparação com a ética médica, na prática era a moral católica, como religião oficial do Estado, que era incorporada como norteadora da moral profissional.

Das primeiras escolas médicas criadas em Salvador e no Rio de Janeiro em 1808 até as atuais 111 escolas presentes na maioria dos estados brasileiros (com 
exceção, até este momento, do Amapá, Rondônia e Tocantins), ${ }^{13}$ temos assistido a um crescimento pouco ordenado, decorrente de pressões políticas locais e/ou interesses particulares, em detrimento de um planejamento educacional racional. Esse crescimento foi mais intenso na década de 60 , quando as restrições existentes na legislação que regulava a criação de novas escolas foram flexibilizadas, com o objetivo de facilitar a expansão. Para entender isso, devemos ter consciência de que havia uma intensa pressão política pela expansão das vagas no sistema de ensino superior, especialmente por parte da classe média, cujos filhos estavam engrossando as listas dos 'excedentes'. ${ }^{14}$ Havia, entretanto, artigos técnicos que propugnavam a ampliação do número de escolas e de vagas como uma estratégia necessária ao desenvolvimento do sistema de saúde no Brasil.

A política de liberalização dos critérios e condições para a criação de escolas médicas no Brasil, especialmente na década de 90, estabeleceu um novo 'surto' de crescimento quantitativo dessas escolas. Muitas iniciaram seu funcionamento sem terem autorizações oficiais, com a certeza de que não seriam impedidas de funcionar, salvo após muitos anos e se o sistema de avaliação oficial em implementação (Avaliação de Escolas e Exame Nacional de Cursos Provão) funcionasse a contento. Até o presente momento, não existem evidências de apoio político a qualquer decisão que leve ao fechamento de alguma escola. Mesmo entre estudantes, históricos defensores ideológicos do ensino de qualidade, quando confrontados com a possibilidade efetiva de uma luta pelo fechamento de escolas sem condições adequadas de funcionamento, optam por defender o funcionamento dessas escolas, supostamente para não prejudicar seus colegas, caracterizando, em nossa avaliação, uma visão política míope, por imediatista.

\section{A Transformação no Ensino Médico: a Reforma Flexner}

0 modelo de ensino médico utilizado no Brasil é fundamentado nos princípios que nortearam a chamada Reforma Flexner, nos Estados Unidos e Canadá, tendo o modelo norte-americano de universidade sido implementado

\footnotetext{
Não é possível assegurar, com exatidão, o número de escolas médicas em funcionamento no país. Existem várias escolas sendo criadas anualmente sem possuírem autorização formal para isso. 0 número aqui apresentado é o utilizado pela Associação Brasileira de Educação Médica (Abem) em 5 de setembro de 2002. Nesta data, o site da Abem informava existirem 59 escolas médicas públicas e 53 privadas (http://www.abem-educmed.org.br/ mapaescolas.htm).

14 'Excedentes' era como eram chamados todos aqueles que eram aprovados nos concursos de vestibular, mas, por não existirem vagas disponíveis para todos, não eram classificados.
} 
apenas em 1968 durante a Reforma Universitária brasileira. Para a exata compreensão de nosso atual sistema de ensino, é mister que nos ocupemos inicialmente da Reforma Flexner.

Chama-se Reforma Flexner o sistema de transformações ocorridas no modelo de ensino da medicina nos Estados Unidos após a publicação, em 1910, do Relatório produzido por Abraham Flexner por encomenda da American Medical Association (AMA) - Associação Médica Americana, instituição máxima representante dos médicos nos Estados Unidos. Embora a publicação do Relatório tenha deflagrado um inequivoco processo de transformações na educação médica naquele país, ele não pode ser entendido sem sua estrita contextualização.

No início do século XIX, a maioria das universidades americanas considerava a educação uma questão de disciplina mental e moral, melhor transmitida e absorvida com currículos prescritivos e tradicionais, nos quais os métodos da ciência moderna não tinham espaço. Mas o pós-guerra ${ }^{15}$ naquele país trouxe também a necessidade de se modernizar as instituições universitárias, já que a economia estava em acelerado crescimento. Podemos dizer que a reforma do ensino médico começou por volta de 1870, como parte do amadurecimento das instituições universitárias nos Estados Unidos, e que seu desenvolvimento deveu-se em grande parte à atuação marcante de dois presidentes universitários, Charles Eliot, de Harvard, e Daniel Coit Gilman, da Johns Hopkins.

Já havia uma idéia reformista entre alguns docentes universitários, inspirada no modelo alemão de universidade, que buscava introduzir aspectos práticos no ensino superior. Para alguns, isso significava uma ênfase no ensino de habilidades úteis; para outros, o incentivo à pesquisa e o desenvolvimento do conhecimento científico. Nas palavras de Charles Eliot, eis um retrato do que era a escola médica norte-americana de então:

A ignorância e a incompetência geral da média dos graduados nas escolas médicas americanas, no momento em que se formam, que os torna inúteis para a comunidade, é algo horrivel de se observar. Todo o sistema de educação médica neste país precisa de uma reformulação. (apud Starr, 1982: 113)

E foi exatamente Eliot, ao assumir a presidência da Universidade de Harvard, que impôs à Faculdade de Medicina sua integração à universidade, o estabelecimento de requisitos mais severos para o ingresso de candidatos, o

15 Refere-se à Guerra Civil Americana (1861-1865). 
aumento da carga horária letiva, a introdução de atividades de laboratório em disciplinas como a fisiologia, química e anatomia patológica, bem como a adoção de normas mais rigorosas para a graduação.

Mas a universidade que mais radicalmente rompeu com o modelo tradicional foi a Johns Hopkins, que criou sua faculdade de medicina em $1893 \mathrm{com}$ um curso de quatro anos de duração e a inusitada exigência de que todos os seus candidatos deveriam ter algum grau universitário prévio. Em sua concepção, a pesquisa científica e o ensino clínico passavam a ser o coração da educação médica. As iniciativas de Harvard e da Johns Hopkins estimularam a competição entre as demais escolas médicas, sendo que muitas foram progressivamente buscando a adaptação ao novo modelo de ensino médico, incompatível com o modelo de escolas puramente comerciais, já que pressupunha elevados investimentos para a contratação de docentes em tempo integral e ampla utilização de laboratórios. Apenas em quatro anos desse processo competitivo, um quinto das 162 escolas existentes em 1896 fecharam.

No início do século XX, a AMA estabeleceu a reforma do ensino médico como sua prioridade, criando um Conselho de Educação Médica composto por cinco docentes médicos das principais universidades do país. Este conselho estabeleceu um padrão de requisitos para o funcionamento das escolas médicas e, em seguida, visitou cada universidade a fim de aprová-las e classificá-las em um ranking de acordo com o grau de adesão ao padrão preestabelecido. Apenas $50 \%$ das faculdades então existentes foram aprovadas com classificação 'A', cerca de 25\% foram classificadas com 'B' (passiveis de recuperação) e as restantes consideradas sem solução. Seu relatório jamais foi publicado, pelo temor dos danos que poderia trazer à corporação e devido à 'ética profissional' que proíbe aos médicos criticarem colegas em público.

Insatisfeita com o resultado da avaliação, a AMA contratou a Fundação Carnegie para o Progresso do Ensino para fazer nova avaliação das escolas, dessa vez sem que médicos participassem do processo. 0 relatório da pesquisa, conduzida pelo educador, graduado em química, Abraham Flexner, foi avassalador, tornando público o desastroso sistema de formação médica de então, que acentuava a discrepância entre o nível de desenvolvimento das ciências médicas e o do ensino médico.

Além de retratar com tons dramáticos o ensino médico, Flexner incluiu em seu relatório sugestões para a transformação do ensino, que podem ser resumidas em: 
- exigência da graduação de nível superior para o ingresso na faculdade de medicina e extensão do curso para quatro anos com mais um ano de internato após a graduação;

- obrigatoriedade do ensino laboratorial;

- estímulo à contratação de docentes, mesmo clínicos, em tempo integral;

- expansão do ensino clínico, especialmente em hospitais;

- vinculação das escolas médicas às universidades;

- ênfase na pesquisa biológica como forma de adequar a educação médica ao desenvolvimento das ciências médicas;

- estímulo à pesquisa e sua vinculação ao ensino.

Nem todas as recomendações do Relatório foram implementadas, pois eram consideradas politicamente inviáveis, como, por exemplo, a redução do número de escolas para 31. Em contrapartida, o Conselho de Educação Médica da AMA legitimou-se politicamente para atuar na prática como instância de acreditação das escolas médicas, uma vez que suas manifestações tinham força política equivalente à de uma Lei. Flexner, por sua vez, parece que preferia um modelo mais flexível para o sistema de formação médica, com mais liberdade para as escolas determinarem o perfil de seus graduados, declarando-se desencantado com a rigidez dos padrões educacionais que passaram a ser identificados com seu nome (Starr, 1982).

0 fato é que, satisfeito ou não, o nome de Flexner passou a ser associado a um rígido modelo de ensino médico, que privilegiava a formação científica de alto nível, o estudo do corpo humano segundo órgãos e sistemas (com o estímulo à especialização profissional), acreditando ser possível o entendimento do homem pelo estudo de suas partes. Este entendimento encontra-se, por exemplo, em Amargo (1996: sem página) que, em uma contundente crítica ao modelo implementado a partir do Relatório Flexner, afirma:

a pessoa humana, antes vista como sujeito do processo terapêutico, respeitada em sua dignidade, vontade, liberdade e razão, transforma-se em objeto de estudos, consumidora de tecnologia, um indivíduo como os objetos de estudo de disciplinas como a química, a física ou a botânica.

Entretanto, não existem elementos concretos que permitam afirmar que antes da Reforma Flexner o paciente desfrutasse de todo este reconhecimento, 
até porque, como salientamos anteriormente, a reforma no sistema educacional buscou incorporar ao sistema de ensino o desenvolvimento já alcançado pelas ciências médicas, tendo como conseqüência principal a padronização da formação e do conhecimento necessários para o exercício profissional.

\section{O Ensino Médico no Brasil Contemporâneo}

Em nosso país, as repercussões da publicação do Relatório foram mais tardias, embora já fosse possivel observar transformações em algumas escolas antes mesmo da primeira metade do século XIX. Nosso modelo universitário, à imagem do modelo europeu, só foi oficialmente reformulado em 1968, com a imposição da Reforma Universitária, que extinguiu as cátedras, substituindo-as pela estrutura departamental, e, no caso do curso médico, criou a obrigatoriedade de um núcleo básico, comum a todos os cursos da área da saúde, e um ciclo profissional.

A maioria dos cursos de medicina, hoje, no Brasil, ainda está organizado de acordo com o preconizado pela Resolução nº 8, de 8 de outubro de 1969. A recente publicação das Diretrizes Curriculares para os Cursos de Graduação em Medicina ainda não repercutiu efetivamente na maioria das escolas. Assim, os cursos ainda têm uma duração média de seis anos. Durante os dois primeiros anos, os alunos dedicam-se ao estudo das chamadas matérias básicas, que a Resolução ํo 8/1969 definiu como: biologia, ciências morfológicas, ciências fisiológicas e patologia (que nos currículos se traduziam nas disciplinas de anatomia, fisiologia, histologia, fisiopatologia, genética, parasitologia, higiene), além de outras freqüentemente incluídas neste momento do curso, sendo muito mais provável que sua inserção neste momento seja devido à falta de tempo disponível para a disciplina no curso profissional do que por considerá-la 'básica' ou por outra estratégia pedagógica (incluem-se psicologia médica e ética, entre as mais comuns).

Na maioria das escolas, entretanto, existe uma discrepância muito grande entre os conteúdos ministrados nos dois primeiros anos e aqueles do ciclo profissional, a saber: "iniciação ao exame clínico, patologia e clínica dos órgãos e sistemas; obstetrícia e ginecologia, pediatria, bases da técnica cirúrgica e da anestesia, psiquiatria, medicina legal e deontologia e estudo da saúde coletiva” (MEC, 1981). Os docentes queixam-se com freqüência e falam da necessidade de reporem alguns conteúdos do ensino secundário (tais como estatística e biologia), e os alunos, da pouca ou nenhuma relação com suas futuras ativida- 
des profissionais dos conteúdos repassados, que privilegiariam a memorização de nomes e fenômenos sem que as desejáveis correlações com a futura prática clínica sejam feitas. ${ }^{16}$

Após os dois primeiros anos, o curso segue no chamado ciclo profissional. Neste momento, os estudantes passam, em geral, a freqüentar as aulas nos hospitais universitários ou de ensino. ${ }^{17}$ As disciplinas previstas neste ciclo possuem a lógica das especialidades médicas, a despeito das indispensáveis medicina interna e semiologia médica. Assim como ocorre no ciclo básico, o currículo previsto na maioria das escolas não viabiliza relações interdepartamentais. Os conteúdos se sucedem sem que se verifiquem as necessárias inter-relações. A carga horária prevista na grade curricular para cada disciplina/especialidade é motivo de intensas disputas entre os diversos departamentos dentro da faculdade, sendo na maioria das vezes meras 'disputas de poder' (o que não difere daquilo que ocorre na maioria das escolas de quaisquer outras profissões).

$\mathrm{Na}$ estranha lógica que perpassa a luta pelo poder em instituições acadêmicas, a importância de um determinado departamento para a instituição e para o curso é verificada pela carga horária total que o departamento detém na grade curricular. Outros parâmetros também muito usados referem-se tanto à quantidade de espaço físico que o departamento ocupa como ao número de seus integrantes indicados para cargos de paraninfo e patronos das turmas (com as exceções de praxe, nesta ordem de importância).

Destaque especial merece ser conferido às aulas práticas ministradas. Estas são consideradas o verdadeiro 'coração' da educação médica, mas, embora com sua carga horária usualmente prevista, poucas vezes são qualificadas e poucas escolas se aventuram a detalhar como essa prática se dará de fato. Até a criação dos hospitais de ensino ou universitários em nosso país, o ensino médico ocorria especialmente nas instituições de assistência médica oferecida aos pobres. 0 pensamento dos médicos de então justificava a utilização dos pobres atendidos nas instituições de caridade sob o argumento de que por estarem oferecendo uma assistência supostamente de alta qualidade, seria natural que

\footnotetext{
16 Não estamos nem nos referindo à dificuldade de se antever, com o tempo devido, quais os conteúdos dessas disciplinas deveriam ser ensinados em função da evolução do conhecimento científico. Referimo-nos apenas à falta de correlação lógica entre conteúdos gerais como parasitologia, epidemiologia e clínica.

17 Hospitais universitários são aqueles vinculados administrativamente a uma universidade. Hospitais de ensino são aqueles que, ainda que não tenham aquela vinculação com uma universidade, acolhem formalmente estudantes de faculdades de medicina especialmente conveniadas com este propósito. Assim, todo Hospital universitário é de ensino, mas a recíproca não é verdadeira. Teoricamente, qualquer hospital pode se tornar um hospital de ensino, especialmente nestes tempos em que a abertura de novos cursos não exige que a nova faculdade tenha o seu próprio hospital de ensino, aceitando os convênios.
} 
aqueles fossem usados como objeto de estudo e ensino. 0 que parecia ser um acordo era, de fato, uma decisão unilateral dos profissionais, uma vez que estes se beneficiavam da vulnerabilidade extrema desses pacientes (na maioria das vezes sem família e sem recursos financeiros), sem que estes tivessem efetivamente a possibilidade de se recusarem a participar.

Tal comportamento contribuiu para fortalecer o paternalismo e o autoritarismo médicos em suas relações com os pacientes de hospitais de ensino. Pode-se afirmar que, particularmente nos serviços públicos de saúde, parece haver um entendimento tácito de que os pacientes possuem direitos limitados. Como veremos mais adiante no capítulo sobre as questões éticas vividas pelos estudantes de medicina dos tempos atuais, ainda hoje, médicos e estudantes (mesmo de universidades públicas e em serviços públicos de saúde) tentam justificar o fato de desconsiderarem o conforto e a vontade do paciente em nome de um suposto privilégio que os pacientes estariam tendo em serem por eles atendidos.

Nos dias atuais, podemos identificar cinco tipos de atividades práticas de clínica aos quais os estudantes podem ser submetidos durante seu processo de formação: ${ }^{18}$

- A prática nas enfermarias - inicia-se, em geral, no ciclo profissional. É o espaço tradicionalmente reservado nos currículos médicos ao contato dos estudantes com seus primeiros pacientes. Sua participação é de envolvimento progressivo, limitando-se inicialmente ao treinamento de anamnese e exame físico. Existe uma forte hierarquia nas enfermarias, com as responsabilidades pelo atendimento recaindo seqüencialmente do Médico-residente (quando existente), estudante do sexto ano de graduação (no chamado internato) até o aluno do terceiro ano. Todas as atividades que os alunos que ainda não estão no internato fazem já foram feitas por alguém mais graduado, impedindo assim que os estudantes se envolvam efetivamente no atendimento prestado. Esta falta de envolvimento no atendimento é uma das razões para a busca pelos estágios extracurriculares.

- As aulas práticas - habitualmente em ambulatórios, podendo ocorrer também em anfiteatros de serviços especializados ou equivalentes.

Algumas das escolas médicas que introduziram modificações substanciais em seus currículos e em suas propostas pedagógicas multiplicaram os seus campos de aprendizagem, incluindo não somente unidades básicas de saúde como também centros comunitários, creches etc. 
Também nesta modalidade, em geral, os alunos são observadores privilegiados de um atendimento e da apresentação de um caso clínico, podendo também ter a oportunidade, em alguns serviços e disciplinas específicas, de examinar um paciente ou mesmo um colega estudante.

- Estágio de internato - é o estágio obrigatório do curso de medicina. Tinha a duração de um ano, mas a tendência mais recente é a de estendê-lo por pelo menos 18 meses e até 24 meses. É neste momento que o estudante efetivamente participa de atendimentos e tem uma crescente responsabilidade sobre o paciente.

- Os estágios extracurriculares - estágios que ocorrem, via de regra, à revelia da faculdade de medicina. Este tipo de estágio é procurado pelos estudantes de medicina com o objetivo de se iniciarem efetivamente na prática profissional, longe do controle de seus professores. Muitos dos estágios são regulares nas instituições, com processo seletivo prévio (mas sem avaliação efetiva). Os maiores problemas relacionados com esta prática são de ordem ética (os pacientes nestes hospitais e clínicas não sabem que serão atendidos por estudantes) e mesmo técnica e pedagógica, já que não há, na maioria das vezes, uma supervisão efetiva do trabalho desenvolvido pelos alunos, podendo daí sobrevir erros de conduta e um aprendizado acrítico de rotinas terapêuticas e métodos diagnósticos.

- Atividades de extensão curricular - muitas universidades, em geral através de suas Pró-Reitorias de Extensão, oferecem aos seus alunos a possibilidade de participarem de atividades comunitárias de pesquisa e/ ou assistência. A rigor, essas atividades poderiam ser classificadas em conjunto com as do item anterior (atividades extracurriculares), mas optamos por fazer referência a elas separadamente não somente por serem formalmente relacionadas com a universidade como pela supervisão oferecida - em geral satisfatória.

Pode-se afirmar, com base no estudo que Campos (1999:189) realizou em diversas escolas, identificadas como 'tipos' básicos das escolas existentes no pais, que

86\% da carga horária dos estágios práticos dos cursos médicos se desenvolvem dentro de Hospitais Universitários, são estes, pois, os espaços que compõem o denominado 'interno’ das faculdades. Durante quase toda a fase de formação clínica, incluindo a de internato, os alunos são treinados 
dentro dos denominados Hospitais Universitários. Algumas escolas têm estágios em centros de saúde, ou em outras modalidades de serviços do SUS; mas, seguramente, pode-se afirmar que seu peso qualitativo e quantitativo (14\% na amostra levantada) na composição curricular é pequeno.

Esta conformação de ensino hospitalar pode ser entendida desde como um reflexo do modelo de ensino baseado nos pressupostos da Reforma Flexner, como também um mero reflexo do modelo de assistência vigente e da estrutura do mercado de trabalho em saúde (ambos denotam claramente que o local de trabalho do médico é, por excelência, o hospital). Os reflexos desses três aspectos no ensino médico são o enfraquecimento das equipes mais generalistas e sua substituição por profissionais especializados e a perda de seus eixos integradores, dividindo em compartimentos o ensino em esferas privadas com pequena integração entre si. Assim, as disciplinas são fragmentadas em pequenos feudos de especialistas que parecem estar mais preocupados em formar jovens especialistas do que repassar os conteúdos indispensáveis para a formação de médicos generalistas.

Este modelo de ensino vem sendo, desde os anos 50, periodicamente criticado, inicialmente nos próprios Estados Unidos e, posteriormente, nos países que o adotaram, como o Brasil. A cada crise, os formuladores de políticas em educação médica têm respondido com soluções que não alteram substancialmente o processo educativo, correspondendo mais a remendos do que a verdadeiras reformas. ${ }^{19}$ Os exemplos, já clássicos, vão da crítica excessiva aos aspectos curativos e ao caráter ultra-especializado dos hospitais universitários e, respectivamente, à criação dos departamentos de medicina preventiva e à criação dos programas de integração docente-assistenciais.

No último quarto do século XX, surgiram, no cenário mundial da educação e da prática médica, duas novas abordagens, uma essencialmente clínica - a Evidence Based Medicine, Medicina Baseada em Evidências (MBE) e sua derivante Evidence Based Learning, e a outra pedagógica, a Problem Based learning, Aprendizagem Baseada em Problemas (PBL). Esta última, por incorporar fundamentos do construtivismo em sua base teórica e prática, vem merecendo dos especialistas em educação a maior atenção e respeito, embora, por si só, seja insuficiente para promover as profundas transformações que o ensino médico requer. Para informações mais detalhadas sobre o histórico de crises na educação médica e os movimentos de reforma,
ver Almeida (1999). 
Vamos nos deter um pouco mais em comentários sobre a MBE, na medida em que sua crescente difusão é, em nosso entendimento, preocupante quando explicitamente incorporada às práticas educativas. A MBE é definida como "um critério de maior certeza de determinados achados e opiniões, apoiado em dados e informações, cuja análise é feita dentro de padrões previamente estipulados" (Drummond \& Silva, 1998: 3), ou uma estratégia para fazer frente à incerteza inerente à prática médica e aos custos de uma medicina cada vez mais baseada em exames complementares. Ainda segundo Drummond \& Silva (1998: 16-17),

o padrão clássico das decisões médicas se fundamenta na combinação de dados coletados sobre o paciente com os conhecimentos de fisiopatologia e terapêutica e com o próprio tirocínio. A [MBE] propõe apenas que esta postura seja confirmada e embasada por fortes evidências externas, garimpadas nas fontes bibliográficas. Pretende ainda que a análise e a aplicação destas evidências suplantem aqueles modelos decisórios, sem recusálos a priori: os critérios clínico-epidemiológicos e estatísticos passariam a ser os novos paradigmas, que poderiam aferir intuições, experiências clínicas não sistematizadas e raciocínios de causa e efeito.

Outros autores, como Atallah \& Castro (2000), vinculados a uma das redes internacionais de difusão da MBE com sede na Escola Paulista de Medicina, afirmam que

a Medicina, durante muito tempo, baseou-se nas experiências pessoais, na autoridade dos indivíduos com maiores títulos acadêmicos e nas teorias fisiopatológicas. (...) Dá especial atenção ao desenho da pesquisa, à sua condução e à análise estatística. No tocante ao método de pesquisa, ele se baseia na associação de métodos epidemiológicos à pesquisa clínica chamada Epidemiologia Clínica. Esse conjunto se completa com métodos bem definidos para avaliação crítica e revisões sistemáticas da literatura médica.

\section{Uma definição mais completa para a MBE é considerá-la como}

a prática de se utilizar a melhor evidência disponível para a tomada de decisões sobre o cuidado dos pacientes, o planejamento e implementação de serviços de saúde e o desenvolvimento de políticas de saúde. Esta abordagem é especialmente preocupada com o uso das estimativas matemáticas da probabilidade e o risco na tomada de decisões. ${ }^{20}$

${ }^{20}$ Conforme http://www.ucl.ac.uk/openlearning/training/index.htm 
Lembremos que a grande transformação observada na Reforma Flexner foi justamente a busca da adequação do ensino médico aos avanços do conhecimento científico de seu tempo. Não é um fato, demonstrável sem contestações, a afirmação de que a medicina não se paute no conhecimento obtido mediante a pesquisa científica. A grande mudança que se observa hoje neste aspecto é que, com o desenvolvimento e a massificação do uso da informática nos últimos anos e, especialmente, com o desenvolvimento da Internet, o conhecimento científico produzido está disponível e acessivel mais rápida e facilmente.

Uma revisão de artigos sobre um determinado problema, que no passado recente demandava muitas e muitas horas de pesquisas em bibliotecas e cujo resultado incluía uma grande probabilidade de não esgotar o assunto ou mesmo de deixar de ler os artigos mais relevantes sobre o tema, hoje, com a microinformática, este conhecimento e seleção está disponível na maioria das casas ou consultórios particulares dos médicos. Outro fenômeno contemporâneo aparentemente relevante é o surgimento de empresas que se dedicam a realizar as revisões sistemáticas que são preconizadas pela MBE, o que torna ainda mais fácil o acesso a estas informações.

Ainda que haja uma preocupação explícita em não menosprezar a experiência clínica, a afirmação de que esta deverá ser confrontada com a bibliografia disponível é, de fato, a sua negação. A experiência clínica só pode ser entendida como uma experiência adquirida com a prática e que, freqüentemente, se contrapõe ao conhecimento disponível nos textos especializados. E como pode a experiência clínica se contrapor ao conhecimento formalmente disponível? Uma das explicações mais razoáveis está no fato de a medicina, em si, não ser uma ciência, mas uma prática que se ampara em diversos campos da ciência. Mas esta contradição de Drummond e Silva, consistente em pretender assegurar o respeito à experiência clínica desde que ela esteja amparada pelo conhecimento científico formal, é apenas um dos pontos de crítica à MBE.

Outro ponto controverso na MBE está no fato de se buscar fundamentar sua estratégia de ação, ou, como ele prefere, estabelecer como novo paradigma, “critérios clínico-epidemiológicos e estatísticos” (Drummond \& Silva, 1998: 17). A utilização de critérios epidemiológicos e estatísticos, se feita de forma criteriosa, pode de fato auxiliar a prática clínica. Com efeito, os dados epidemiológicos referem-se a populações, não a casos específicos, assim como uma eventual certeza estatística não passa, a rigor, de uma boa probabilidade, havendo sempre uma margem de erro associada que pode, ao desviar o médico de seu raciocínio 
e experiência clínica, levar a conseqüências danosas aos pacientes concretos e singulares que freqüentam seu consultório.

A MBE, contudo, "ao exigir formulação precisa das questões, requer, implicitamente, exame acurado do paciente, indagação exaustiva dos respectivos dados e contemplação da situação concreta, nela incluídas suas necessidades emocionais" (Drummond \& Silva, 1998: 16), o que, no entender de Drummond e Silva, asseguraria a humanização do relacionamento médico/paciente. Esta é, em verdade, mais uma armadilha em que pessoas, mesmo bem intencionadas, podem cair ao discutirem a necessidade de se melhorar o padrão da relação médico/ paciente: reduzir a discussão ao plano da trama de afetos e desejos. Considerar as necessidades psicológicas dos pacientes por si só não significa o respeito à condição humana desse paciente, muito menos o respeito à sua autonomia. No caso, os autores confundem a autodeterminação do paciente com suas necessidades emocionais e, da mesma forma, com a necessidade de receber informações mais precisas sobre a evolução e prognóstico de sua enfermidade.

Resumindo, parece-nos que a MBE pode ter uma grande contribuição a oferecer na formação e prática médicas, devido a seu enfoque estatístico e 'quantitativo', mas não pode ser elevada à condição de método para a obtenção da certeza absoluta ou, ainda, de instrumento básico para a consulta clínica, visto que esta sempre deverá dar-se no encontro/desencontro entre um médico (ou prestador de serviços) e um paciente (ou usuário), no qual o aspecto qualitativo é constitutivo da própria relação e, provavelmente, de seus resultados. Ademais, e querendo ser rigorosos com as palavras, muitas das assim chamadas 'evidências' são de fato indícios a serem interpretados, dando, portanto, margem a erros de interpretação, inclusive com as técnicas diagnósticas mais sofisticadas.

\section{Questões Contemporâneas na Educação Médica no Brasil}

Do início da década de 60 até os dias de hoje, ocorreu um enorme crescimento no número de escolas médicas, de estudantes de medicina e de graduandos. Esse crescimento foi determinado, entre outras razões, pela necessidade de se desenvolver o setor saúde no Brasil e por necessidades políticas circunstanciais (como a decisão de se criar ao menos uma universidade pública federal por estado e de estimular a participação do setor privado da economia 
no setor educacional). Após um crescimento avassalador no número de escolas médicas (em 1968 chegaram a ser criadas 13 escolas), a corporação médica conseguiu frear este crescimento durante a década de 70 até o final dos anos 80 , quando novamente voltou a ser autorizada a criação de novas escolas médicas.

Esta liberação foi aceita pela corporação médica porque foram estabelecidas, pelo governo federal, normas que regulariam qualquer tentativa de criação. Tais normas nunca chegaram a ser realmente efetivas e cumpridas, já que a maioria dos grupos de investidores interessada em criar escolas médicas encontrou caminhos para desrespeitar o decreto presidencial, com a conivência de instâncias administrativas do Ministério da Educação.

A política adotada pelo governo do presidente Fernando Henrique Cardoso, a despeito de umas tímidas e frustradas tentativas de impedir a criação de novos cursos médicos à sua revelia no início de seu primeiro mandato, passou a admitir a livre criação desses cursos e a investir em uma política de avaliação do funcionamento dessas escolas, com critérios muito semelhantes aos utilizados pela Comissão de Ensino Médico da Associação Médica Americana no início do século XX (conforme descrito anteriormente). No que tange ao currículo médico, foi assegurada uma maior autonomia às escolas em sua determinação, limitandose o governo federal a listar o perfil desejado para os estudantes de medicina e criar um exame nacional para todos os graduandos. Segundo a Portaria 126 de 1ํ de fevereiro de 1999, do ministro da Educação, publicada no DOU de 2 de fevereiro de 1999, o perfil delineado para os graduandos em medicina é:

a) cidadão com atitude ética, formação humanística e consciência da responsabilidade social;

b) capacidade de compreender, integrar e aplicar os conhecimentos básicos à prática clínica;

c) formação para atuar em nível primário de atenção e resolver, com qualidade, os problemas prevalentes de saúde;

d) formação para o atendimento das urgências e emergências;

e) capacidade de lidar com os múltiplos aspectos da relação médico-paciente;

f) formação para aquisição e produção do conhecimento, com capacidade de aprendizado contínuo durante toda a vida profissional;

g) capacidade de atuar em equipe interdisciplinar e multiprofissional. (Brasil, 1999)

Já em seu artigo 5으, as diretrizes curriculares apontam os conteúdos essenciais na perspectiva desse perfil e habilidades definidas: 
a) Ciências morfológicas: Anatomia, Biologia Celular e Molecular, Embriologia, Genética, Histologia;

b) Ciências fisiológicas: Bioquímica, Biofísica, Farmacologia e Fisiologia;

c) Mecanismos de defesa e agressão: Imunologia, Microbiologia, Parasitologia e Patologia Geral;

d) Ciências do comportamento aplicadas à saúde: Psicologia Médica;

e) Saúde Coletiva, Epidemiologia, Bioestatística, Saúde do Trabalhador; Administração em Saúde;

f) Ciências sociais aplicadas à saúde: Ética, Bioética e Deontologia;

g) Iniciação ao exame clínico: Propedêutica e Imagenologia;

h) Metodologia científica;

i) Conteúdos básicos das especialidades clínicas: Anestesiologia, Cardiologia, Dermatologia, Emergências Clínicas, Endocrinologia, Gastroenterologia e Nutrição, Geriatria, Hematologia, Imunologia Clínica e Alergia, Infectologia, Nefrologia, Neurologia, Oncologia, Patologia Especial, Pneumologia, Psiquiatria, Reumatologia, Medicina Legal;

j) Aspectos clínicos das seguintes especialidades: Oftalmologia, Ortopedia, Otorrinolaringologia e Urologia;

k) Cirurgia: Bases da Técnica Cirúrgica e Anestésica, Cirurgia Ambulatorial, Prática em Centro Cirúrgico e Propedêutica Cirúrgica;

l) Ginecologia e Obstetrícia: aspectos clínicos e cirúrgicos da Ginecologia Geral e Obstetrícia Geral;

m) Pediatria: Medicina geral da criança, Puericultura e Nutrição. (Brasil, 1999)

Tais iniciativas, polêmicas e muito questionadas pela corporação médica através de suas diversas entidades representativas, ainda não demonstraram sua eficácia no enfrentamento dos problemas da educação médica no Brasil, mas seus resultados após o primeiro ano são extremamente alvissareiros.

Desde a primeira tentativa governamental de se instituir um sistema de avaliação do ensino médico externo à corporação (1990), as diversas entidades representativas dos médicos se uniram na criação do que desejavam que fosse 0 Sistema de Avaliação utilizado (criado e executado pela corporação médica): a Comissão Interinstitucional Nacional de Avaliação do Ensino Médico (Cinaem).

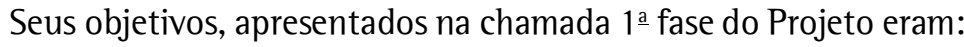

1. Avaliar o Ensino Médico brasileiro, visando sua qualidade para atender às necessidades médico-sociais da população.

2. Propor medidas a curto, médio e longo prazo que venham sanar as deficiências hoje encontradas.

3. Criar mecanismos permanentes de avaliação das Escolas Médicas. 
4. Criar mecanismos para desenvolver programas de Educação Médica Continuada. (Basile, 1999: 308)

As conclusões da chamada $1^{\underline{a}}$ fase, relacionadas com um diagnóstico da infra-estrutura das escolas médicas brasileiras, apesar dos graves erros cometidos em sua análise devido à existência não controlada de vieses de informação, foram difundidas e refletiriam uma certa situação de caos generalizado, sem que nenhum grupo de escolas se destacasse positiva ou negativamente dos demais. 0 erro aqui assinalado deveu-se ao fato de a equipe técnica ter considerado como sem recursos (físicos ou humanos) aquelas faculdades que deixaram de apresentar respostas em algum dos 266 quesitos que compunham o questionário.

Assim, por exemplo, quando uma faculdade deixava de responder sobre o número de consultórios médicos existentes em seu hospital universitário, sua falta de resposta era computada como capacidade instalada 'zero' para consultórios médicos. 0 erro, apesar de ter sido repetidas vezes anunciado e algumas vezes admitido, jamais foi corrigido em publicações.

Sua $2^{\mathrm{a}}$ fase, caracterizada como um estudo de coorte na avaliação dos discentes, com a aplicação de questionários de avaliação cognitiva em diversos momentos, a realização de um estudo do perfil dos docentes médicos e da avaliação do modelo pedagógico, contou com a participação voluntária de apenas 47 escolas médicas.

A 3 a fase manteve a estratégia de avaliação dos alunos através de uma prova e busca à implementação de mudanças na escola médica com a criação de comitês assessores e a mobilização de docentes e discentes pela transformação.

Após dez anos de funcionamento, a Cinaem ainda não conseguiu produzir resultados concretos que afastassem a imagem de uma ação corporativista e que sugerissem ser este o caminho mais eficaz na construção de alternativas ao modelo vigente no Brasil. Persiste-se dando muita ênfase na identificação e na elucidação dos entraves do processo educativo, enfoca-se ora o docente, ora o discente, ora a infra-estrutura e os meios de ensino, mas parece que persiste ainda a falta de idéias, indicada por Martini (1990), embora esta falta não seja apenas latino-americana. Em suma, mais do que falta de vontade de mudar, o que parece prevalecer é a total falta de idéia de para onde e como ir. ${ }^{21}$

\footnotetext{
No ano de 2002, os Ministérios da Educação e da Saúde, em parceria com a Abem, criaram o Programa de Incentivo para Mudanças Curriculares para Faculdades de Medicina que, pela primeira vez, aponta não apenas uma direção concreta para as mudanças, respeitando as peculiaridades, idiossincrasias e autonomia de cada faculdade, mas também oferecendo recursos financeiros e consultorias para o processo.
} 
Esta crítica, todavia, não deve ser entendida como se fôssemos simplesmente contrários ao esforço empreendido pela Cinaem, como poderão assegurar aqueles que não querem discutir o assunto, por razões mais ou menos nobres. Entendemos que a Cinaem possibilitou a manutenção da discussão sobre a educação médica na agenda de diversos atores, com alguns resultados louváveis e meritórios. Mas a rigor, quando comparamos como está o ensino médico hoje com o de 1990, poucas das mudanças observadas podem ser corretamente atribuíveis ao processo empreendido pelas entidades que compõem a Cinaem.

Tomemos, como exemplo, a questão da formação humanística do estudante de medicina, que constitui o enfoque de nosso estudo. Não é difícil encontrar, nos diversos anais de encontros de profissionais interessados em educação médica, recomendações ou observações sobre a importância de se investir neste sentido na formação.

Da Declaração de Edimburgo, na qual está propugnado que se deve "organizar os programas de ensino e os sistemas de avaliação de modo a garantir a aquisição das competências profissionais e dos valores sociais e não somente a memorização da informação" (Chaves \& Rosa, 1990: 138) até a recente World Medical Association Resolution on the Inclusion of Medical Ethics and Human Rights in the Curriculum of Medical Schools World-Wide (WMA, 1999), ${ }^{22}$ para ficarmos em apenas dois momentos significativos mundialmente, a literatura está cheia de exemplos. Mas parece que ainda estamos no início de uma caminhada no sentido de conhecer melhor esta realidade que queremos mudar.

Temos sido razoavelmente satisfatórios na realização de macrodiagnósticos, mas pouco atentos a situações específicas. Talvez tenhamos sido bons o suficiente para a crítica política, mas incapazes de elaborar a análise técnica, e é nesta perspectiva que se insere o presente livro: aprofundar as discussões sobre o que é a formação moral do estudante de medicina, sobre o que ele vivencia em seu dia-a-dia de aluno e como ele reage a estas situações. Para tal, antes de apresentarmos os resultados de nossa pesquisa, refletiremos sobre as teorias explicativas sobre o desenvolvimento moral, mais especificamente sobre as teorias da 'aprendizagem social' e a 'estruturalista'.

\footnotetext{
“1. considerando que a Ética Médica e os Direitos Humanos constituem-se uma parte integrante do trabalho e cultura da profissão médica e 2. considerando que a Ética Médica e os Direitos Humanos constituem-se uma parte integrante da história, estrutura e objetivos da Associação Médica Mundial (AMM); 3. está por este meio resolvido que a AMM recomenda fortemente a Escolas Médicas do mundo inteiro que o ensino de Ética Médica e Direitos Humanos sejam incluídos como um curso obrigatório em seus currículos” (WMA, 1999).
} 


\section{2}

\section{Introdução ao Estudo da Formação Moral dos Estudantes de Medicina}

O pensamento redutor atribui a 'verdadeira' realidade não às totalidades, mas aos elementos; não às qualidades, mas às medidas; não aos seres e aos entes, mas aos enunciados formalizáveis e matematizáveis. (Morin, 1996: 27)

No capítulo anterior, apresentamos um rápido e breve pano de fundo sobre o processo de formação médica, suas influências mais gerais, seu histórico e algumas características do momento político de questionamento pelo qual passa. 0 estudo das profissões oferece, via de regra, grande ênfase no papel que o conhecimento exerce para sua consolidação como corporação e para o exercício de sua autoridade cultural e técnica. Está claro que sem um conhecimento específico e sem que esse conhecimento seja destinado à resolução de problemas específicos da sociedade (com eficácia, naturalmente) uma profissão não se constitui ou não sobrevive (Starr, 1982).

Mas a formação médica, assim como qualquer outra atividade educativa, está longe de se restringir a uma simples capacitação técnica ou a uma transmissão 'asséptica' deste conhecimento, ainda que isso possa ser depreendido, por exemplo, da leitura do Parecer 506/69 do Conselho Federal de Educação, que fundamentou a aprovação da Resolução no8/69 e que fixava o conteúdo mínimo dos cursos de graduação (Santos, 1981).

Neste Parecer, Santos elaborou uma crítica coerente ao modelo de ensino então vigente: abordou de forma apropriada a discussão sobre a dicotomia existente entre a saúde individual e coletiva; discutiu a especialização precoce dos estudantes de medicina; iniciou a discussão sobre as relações tantas vezes conflituosas entre hospitais, escola e ensino médico e colocou de forma inovadora a questão da integração curricular no ensino da medicina. Nenhuma palavra, entretanto, foi dedicada a nenhum aspecto da relação médico/estudante/ paciente. Nesse momento, a concepção que parece ainda prevalecer é a de que 
não há necessidade de maiores investimentos educacionais com o propósito de preparar os estudantes para esta relação.

No início da década de 70, surgem as primeiras disciplinas de psicologia médica e os primeiros livros dedicados à divulgação da utilização de fundamentos da psicologia na medicina. Assim, a 'humanização' da relação médico/estudante/paciente teve sua abordagem inicial com o respeito aos processos psicopatológicos dos pacientes. Considerava-se a possibilidade de o paciente estar desenvolvendo uma 'somatização devido a problemas psicológicos' (invertendo o sentido tradicionalmente dado pela medicina antes do desenvolvimento da psicanálise que, como afirma Perestrello (1974), buscava em doenças orgânicas a responsabilidade para a sintomatologia psíquica).

Via de regra, esta somatização era diagnosticada como o tradicional Distúrbio Neurovegetativo de outrora ou o já popular 'piti' (corruptela da palavra pitiático ${ }^{23}$ da atualidade. Seja qual for a palavra ou expressão utilizada para designar este evento clínico, muito freqüentemente os médicos menosprezam ou desconsideram o fenômeno como uma manifestação clínica de importância e não raramente optam por condutas pouco adequadas para o real bem-estar do paciente. ${ }^{24}$

Mas a humanização passou a ser considerada como a atenção a eventuais manifestações psicossomáticas de enfermidades e às possiveis interferências que o estado psíquico possa provocar na história natural da doença. Ainda hoje, é freqüente a restrição, no campo da psicologia clínica, a toda e qualquer referência à humanização da assistência ou, mais recentemente, no Brasil, ao ensino da ética em bases não deontológicas. Mas este assunto será abordado mais adiante, quando estivermos discutindo as estratégias utilizadas pelas escolas médicas para apoiar ou estimular o desenvolvimento moral dos estudantes de medicina.

Voltemos, ainda que brevemente, aos nossos questionamentos sobre a dimensão menos discutida na educação médica no Brasil: a transmissão de valores e a conformação da identidade profissional na graduação. Toda profissão possui uma cultura específica. Esta se manifesta desde a utilização de um

23 Segundo o Novo Dicionário Aurélio da Língua Portuguesa, é relativo ao pitiatismo: "designação dada à histeria por J. Babinski, médico francês, e que constitui afecção mental produzida por sugestão, sendo o paciente passível de ser curado, também, por sugestão" (Ferreira, 2000: 1341).

24 Alguns alunos fizeram referência, em nossas entrevistas, a um fato que nós mesmos já tivemos a oportunidade de observar quando tínhamos atividade clínica: a adoção de condutas que podem ser reconhecidas como 'castigos' infringidos pelos médicos aos pacientes 'difíceis', como, por exemplo, a administração de medicamentos dolorosos ou a manutenção do paciente no setor de emergência do hospital em observação sem que haja efetivamente indicação clínica para tal. 
linguajar próprio, com expressões só perfeitamente compreensíveis pelos já iniciados, e que costuma ser identificada como um conhecimento verdadeiramente esotérico. Esta cultura específica possui valores igualmente específicos.

Nosso propósito nas páginas que se seguem é o de discutir como esses valores são perpetuados ou, mesmo, se são. Será que as disciplinas de ética médica são as responsáveis por este papel tão estratégico para a profissão? Quais são os estratagemas adotados pela medicina para obter tamanha homogeneidade moral entre seus membros? Como os estudantes são inseridos nesta cultura? Como é possível se explicar, e entender, a aderência dos estudantes ao Código de Ética e aos valores profissionais? Como os estudantes de medicina aprendem a se relacionar com seres humanos em uma condição de pacientes? Como aprendem a se comportar e como lidam com situações em que são compelidos a tomarem as decisões mais adequadas, sabendo que essas decisões poderão interferir de forma significativa na vida desses indivíduos? Será que o que orienta sua atuação é a formação moral que cada indivíduo traz da educação familiar? Qual o papel desse histórico educacional na sua formação moral? Será que para orientar suas atitudes basta o 'bomsenso', como é voz corrente entre os estudantes ou o Código de Ética Médica, como pressupõem as normas corporativas?

Existem basicamente três modelos teóricos explicativos para o processo de desenvolvimento moral: a visão estruturalista/cognitivista, que tem suas origens na filosofia de Immanuel Kant e nos estudos empíricos e na teoria de Jean Piaget; as teorias do aprendizado social, cujos antecedentes estão no empirismo de John Locke, no behaviorismo de John Watson, e na visão psicanalítica, cuja origem está nos trabalhos de Sigmund Freud (Windmiller, 1980: 2-5).

Um esclarecimento torna-se necessário antes de nos aventurarmos neste universo teórico. Trata-se da própria compreensão do conceito de processo de socialização. Utilizado amplamente pela sociologia e pela psicologia, pode muitas vezes ser confundido com as diferentes correntes explicativas para o processo. Assim, utilizamos aqui o termo socialização como um processo social no qual indivíduos adquirem habilidades, conhecimento, valores e os papéis consonantes com sua posição em um grupo ou sociedade, ou, em outras palavras, o processo através do qual a personalidade é formada, como o resultado das influências sociais. Ou ainda, de uma forma mais direta, poderíamos dizer que é a transformação de um ser biológico (ou um 'pacote de células') em um ser social. 
Portanto, sempre que nos referirmos à socialização, estaremos nos referindo ao processo geral, sem que isso signifique a adoção de uma determinada corrente teórica explicativa. Assim, o processo de socialização inclui o que estamos referindo como 'processo de desenvolvimento moral', ou seja, o processo de valorização de atos, comportamentos, características do indivíduo etc. (como o desenvolvimento da capacidade de refletir sobre aspectos morais e realizar julgamentos pessoais de ordem moral, escolhendo entre o que é certo e errado, justo e injusto, bom ou mau etc.) - ainda que também este termo esteja em geral mais associado às teorias cognitivistas.

Estas três visões sobre o processo de desenvolvimento moral, ou, para ser mais específico, sobre a maneira como se desenvolve no indivíduo sua capacidade de refletir sobre aspectos morais de sua vida e, portanto, de agir moralmente, são, em muitos aspectos complementares, apesar das eventuais (e às vezes nem tão eventuais assim) contradições e antagonismos.

Com grande freqüência observamos na literatura uma defesa quase religiosa dos pontos de vista dos autores, ou de seus mestres de quem são seguidores, fazendo com que as idéias que não são originárias da mesma corrente de pensamento sejam vistas como graves heresias e apresentadas muitas vezes com severas distorções, ou, no mínimo, com seus aspectos mais críticos enfatizados. Assim é que estruturalistas costumam enfatizar, em suas críticas aos seguidores da teoria do aprendizado social, o empirismo de John Locke, que afirmava "que não existiam idéias inatas e que, ao nascer, a mente do indivíduo é uma tábula rasa na qual se registram os estímulos do meio que, por sua vez, determina suas respostas comportamentais" (Rosa, 1996: 54), sem permitir aos seus leitores entender que a teoria criticada também evolui em seus pressupostos e os reavalia. Da mesma forma, os psicanalistas afirmam que os estágios de desenvolvimento moral de Piaget/Kohlberg são estanques sem transição ou, ainda, os não psicanalistas enfatizam a afirmação de que no pensamento de Freud a formação do superego, através da resolução do complexo de Édipo, em torno dos seis anos, encerra qualquer desenvolvimento.

Nossa proposta, neste trabalho, embora não desconheçamos as diferenças significativas entre as diferentes correntes teóricas, é a de identificar os elementos relevantes nas diversas teorias que nos subsidiem em nossa empreitada - desvendar os caminhos da formação moral do estudante de medicina. Promover esta mistura teórica não é um sinal de incompreensão das referidas teorias, mas a convicção de que elas, isoladamente, são insuficientes para escla- 
recer, a contento, o processo de desenvolvimento moral do indivíduo. Embora, como ficará claro ao longo do trabalho, entendamos que a fundamentação teórica cognitivista é a que reúne as melhores bases explicativas para o processo, isso não significa que devamos desprezar as demais, em seus aspectos não conflitantes e que sustentam perspectivas complementares. Por não se tratar de uma discussão ideológica, ou de gosto, ou de afinidade, não vemos razões para desconsiderar as contribuições pertinentes de outras bases teóricas.

Das três visões que buscam explicar o processo de desenvolvimento moral, concentraremos nossa atenção em duas: as teorias de aprendizagem social e a estruturalista. A exclusão da visão psicanalítica não se deve, contudo, a uma negação das contribuições à nossa discussão, mas um reconhecimento da impossibilidade de termos acesso ao 'inconsciente' através de métodos de pesquisa como os utilizados por nós.

Nosso propósito, neste e no próximo capítulo, é o de, revendo a literatura existente sobre essas duas visões teóricas explicativas do desenvolvimento moral, encontrar elementos que contribuam para o entendimento de como os estudantes de medicina agem em seu aprendizado profissional e como as faculdades podem contribuir para a preparação do estudante para lidar com essas situações durante sua formação e na vida profissional.

\section{Processo de Socialização}

\section{Socialização Primária}

A abordagem que se segue para a descrição do processo de socialização é amplamente baseada no trabalho de Berger \& Luckmann (1990), que advogam o princípio da 'construção social de realidade'. Esta concepção teórica coloca-se como contrária à sociologia estrutural e positivista, rejeitando a noção de que eventos ou fenômenos sociais tenham existência independente e objetiva e buscando identificar os métodos pelos quais os membros da sociedade criam ou constroem a realidade. Para um melhor entendimento da diferença, considere-se a análise apresentada por Drislane \& Parkinson (2000: sem página) sobre os suicídios:

Durkheim, por exemplo, era um positivista e um estruturalista e argumentou que o suicídio tem uma existência objetiva, independente dele e 
quaisquer outros. Ou seja, haveria algo sobre o modo de morrer que constituiu algo como um suicídio. Um defensor da construção social da realidade diria que aquele suicídio é apenas um rótulo para uma morte e é criado, ou construído, pelas considerações que pessoas como a polícia, família, ou juizes fazem da morte.

Uma sociedade é necessariamente uma criação do homem e possui uma existência objetiva. Desde que o homem existe como espécie, vive em agrupamentos, maiores ou menores, fixos em determinado espaço geográfico ou errantes - ele vive em sociedades. Essas sociedades se diferenciam, ao longo da história da humanidade, em mais ou menos complexa, mas o homem é reconhecidamente um 'animal social'. Contudo, o desenvolvimento de um indivíduo desta espécie não é assegurado apenas por padrões ou características biológicas. ${ }^{25}$ "Embora ele não nasça membro de uma sociedade, ele possui a predisposição para a sociabilidade e torna-se membro da sociedade" (Berger \& Luckmann, 1990: 173).

Existem diversos casos relatados na literatura científica que demonstram que o isolamento de contato social por longos períodos apresenta sinais de retardo severo no desenvolvimento emocional, social, intelectual e mesmo biológico. 0 convívio social é condição necessária para que os potenciais de desenvolvimento humano sejam atingidos.

Assim, como dizíamos, a sociedade é uma realidade objetiva, mas também é subjetiva, sendo que para o correto reconhecimento destes aspectos deve-se entender a sociedade "em termos de um processo dialético em curso, composto de três momentos, exteriorização, objetivação e interiorização"26 (Berger \& Luckmann, 1990: 173), que não devem ser pensados como ocorrendo em uma seqüência temporal, mas simultaneamente. Da mesma forma, um membro individual desta sociedade exterioriza seu próprio ser no mundo social e 0 interioriza como realidade objetiva. Para Tedesco (1995), pelo fato de as características mais relevantes neste processo ocorrerem entre gerações, isto confere ao processo um caráter necessariamente reprodutor.

\footnotetext{
25 A despeito da posição defendida por correntes teóricas como a Sociobiologia e a Psicologia Evolucionária, que defendem a idéia de que muitos dos comportamentos sociais dos humanos são produtos da evolução da espécie, havendo uma predisposição genética para certos padrões de comportamento social que seriam úteis para a espécie. 0 exemplo mais comumente apresentado é a predisposição para ajudarem-se mutuamente como uma condição necessária para a sobrevivência da espécie.

26 Entende-se a interiorização como "a apreensão ou interpretação imediata de um acontecimento objetivo como dotado de sentido, isto é, como manifestação de processos subjetivos de outrem, que desta maneira torna-se subjetivamente significativo para mim” (Berger \& Luckmann, 1990: 173).
} 
São identificadas duas fases no processo de socialização: "a primária refere-se à fase em que o indivíduo se converte em um membro da sociedade e ocorre no período da infância e a secundária a qualquer processo posterior que induza o indivíduo a interiorizar setores particulares do mundo objetivo da sua sociedade" (Tedesco, 1995: 99).

Tradicionalmente, na socialização primária, os principais agentes são os pais e a interiorização que ocorre é a do mundo deles, que se apresenta não apenas como a única realidade possivel, mas também como a única existente. A interiorização é o primeiro passo para a compreensão do outro e, em seguida, para a apreensão de seu mundo como uma realidade social dotada de sentido. Imagine-se, como exemplo, o choro ou o riso. Estes fenômenos são inicialmente sem sentido para a compreensão de uma criança de tenra idade. Eles adquirirão significados a partir da apreensão do significado deles para o outro, o que não significa que necessariamente a compreensão desses fenômenos seja adequada ou correta. 0 lacrimejar pela irritação ocular pode se equivaler na sua interpretação ao choro do sofrimento ou o riso da hilaridade ao riso em decorrência de emoção excessiva ou doença mental. 0 nexo de motivações será estabelecido posteriormente, mas a identificação ${ }^{27}$ mútua já está estabelecida.

A socialização primária ocorre com alguns filtros de significação que estão diretamente relacionados com a realidade social em que esta se dá, o 'lugar' dos adultos na estrutura social e as características específicas dos agentes socializadores. Bourdieu, em sua discussão sobre espaço social e espaço simbólico, utilizando-se de seu conceito de habitus também explicita a importância da localização do indivíduo na estrutura social na configuração de seu ponto de vista da sociedade:

De maneira mais geral, o espaço de posições sociais se retraduz em um espaço de disposições (ou do habitus). (...) A cada classe de posições corresponde uma classe de habitus produzidos pelos condicionamentos sociais associados à condição correspondente e, pela intermediação desses habitus e de suas capacidades geradoras, um conjunto sistemático de bens e de propriedades vinculado entre si por uma afinidade de estilo. (Bourdieu, 1996: 21)

Entretanto, nem tudo se resume à posição do indivíduo, já que os habitus são princípios geradores de práticas distintas e distintivas - o que o operário

0 conceito de identificação é largamente utilizado na psicanálise e por algumas correntes teóricas da sociologia. Pode ser entendido em dois sentidos: transitivo, correspondendo ao verbo identificar, e reflexo, correspondente ao verbo identificar-se. Este último abrange, na linguagem corrente, uma série de conceitos psicológicos, como imitação, empatia, simpatia, contágio mental, projeção etc. (Laplanche, 1995). 
come e, sobretudo, sua maneira de comer, o esporte que pratica e sua maneira de praticá-lo, suas opiniões políticas e sua maneira de expressá-las diferem sistematicamente do consumo ou das atividades correspondentes do empresário industrial; mas são também esquemas classificatórios, princípios de classificação, princípios de visão e de divisão e gostos diferentes. Eles estabelecem as diferenças entre o que é bom e mau, entre o bem e o mal, ent2e o que é distinto e o que é vulgar etc., mas eles não são os mesmos. Assim, po2 exemplo, o mesmo comportamento ou o mesmo bem pode parecer distinto para um, pretensioso ou ostentatório para o outro e vulgar para um terceiro (Bourdieu, 1996).

A interiorização da realidade social dos pais, na socialização primária, dá-se em um ambiente com grande componente afetivo e emocional, o que torna esses conteúdos ainda mais significativos para o indivíduo em sua vida adulta. Chega-se a relacionar, por esta razão, o sucesso dos aprendizados posteriores à sua relação com o que foi socializado primariamente. Tal estrutura e conteúdos não são imutáveis, já que o desenvolvimento do pensamento crítico do jovem, usualmente a partir da adolescência, lhe permite analisar e criticar sua própria formação.

Na socialização primária não se insere a questão de identificação dos outros significativos, já que não existe a opção de escolha. A identificação com os pais é contingenciada pela própria natureza da relação estabelecida. Para Berger \& Luckmann (1990: 181), inclusive, "a socialização primária realiza assim o que pode ser considerado o mais importante conto do vigário que a sociedade prega ao indivíduo, ou seja, fazer aparecer como necessidade o que de fato é um feixe de contingências, dando desse modo sentido ao acidente que é o nascimento dele”, em determinada família e em determinado espaço da estrutura social.

\section{Socialização Secundária}

A socialização secundária é a interiorização de submundos, ou subculturas específicas, diretamente relacionadas à complexidade da divisão do trabalho. É virtualmente inevitável que todo indivíduo se submeta a algum tipo de socialização secundária. 0 mais habitual é que ao longo de sua vida, desde, por exemplo, o início do aprendizado escolar até a sua formação em determinada profissão, múltiplos e díspares agentes de socialização interajam com o indivíduo, o que não implica necessariamente cargas afetivas ou emocionais e, em contrapartida, supõe uma certa coerência com os conteúdos da socialização primária (e, por conseguinte, com a estrutura básica do sujeito) para seu pleno êxito. 
Na socialização secundária, a questão da identificação se coloca de forma diferente da primária. Enquanto nesta, como já vimos, a identificação com o outro (pais) é compulsória, naquela, isto não é uma condição necessária. A criança estabelece uma relação de identificação com seus pais, mas não necessariamente com seus professores. Pode até ter essa identificação, o que facilitará a socialização, mas isso não é uma condição sine qua non. Tal fato justifica o fenômeno de dois professores ministrando conteúdos idênticos e com o mesmo método obterem não apenas resultados diferentes como o fato de esses conteúdos serem modificados com mais facilidade pelo sujeito, em outros momentos de socialização. Esses conteúdos, desprovidos da inevitabilidade e da carga emocional dos da primária, podem ser facilmente substituídos por outros.

Em contrapartida, um aspecto que não pode ser desconsiderado é a motivação do sujeito. Esta motivação pessoal pode ser resultado da própria socialização primária sob a forma de valorização de determinados aspectos ou como resultado da identificação que o sujeito faz do agente secundário como um modelo, ou ainda por processos (conscientes ou não) de identificação do agente com seus próprios pais (modelos primários). Exemplificando, o adolescente pode se identificar com um artista de cinema, um astro da música ou um esportista, da mesma maneira que um adulto pode se identificar com um médico bem-sucedido e construir assim o seu ideal profissional a ser perseguido. Para os psicanalistas, esta identificação "se relaciona apenas secundariamente com fantasias de substituir um objeto admirado com a finalidade de tirar proveito, ao apropriar-se dos direitos e propriedades da pessoa admirada" (Brenner, 1975: 59).

0 processo de socialização não permite a interiorização da totalidade da realidade social. Existe sempre a perspectiva colocada pelo tipo de estrutura social em que o sujeito está inserido e pela sua localização nela. Tedesco (1995: 102), analisando a situação da América Latina, assinala o caráter reprodutivo da estrutura da distribuição social do conhecimento do processo de socialização, na medida em que ele "reproduz a estrutura social do conhecimento existente na sociedade e, com ele, materializa no plano cultural e simbólico a reprodução das relações sociais globais". Esta perpetuação da estrutura social, de acordo com a visão teórica, se dá exatamente pelos conteúdos da socialização primária e pelas possibilidades que são oferecidas na e para a socialização secundária. Sendo o acesso ao sistema escolar diferenciado de acordo com a localização do sujeito na estrutura social, é também diferenciado nas características qualitativas nas oportunidades educacionais surgidas. 
Bourdieu nos oferece, com o conceito de capital cultural, uma abordagem explicativa, em alguns pontos semelhante, para esta situação. Menos peremptório, Bourdieu (1996: 35) atribui à instituição escolar o papel de "contribuir para reproduzir a distribuição do capital cultural e, assim, a estrutura do espaço social”. Dessa forma, deixa espaço aberto para eventuais deformações resultantes do processo, mais ou menos significativas, e que ocorrem em toda e qualquer sociedade.

Uma outra forma de entendimento das possíveis variações nos resultados da socialização é o entendimento de que o êxito seja verificado no ajuste entre a realidade objetiva e a subjetiva, o que torna impossível o êxito total ou o fracasso total, deixando uma ampla margem de variações no seu resultado.

\section{Socialização profissional - medicina}

A socialização profissional é um caso específico de socialização secundária - já formalmente na idade adulta. Como tal, seus efeitos possuem relação direta com os conteúdos da socialização primária, da sua inserção na estrutura social e da construção da personalidade do sujeito. ${ }^{28}$ Condições, como o gênero, terão tanta importância na socialização profissional como tem em outros processos de socialização. Entendemos que a construção da identidade feminina é fator relevante para compreendermos os efeitos da socialização em medicina, embora não sejam derivadas necessariamente do processo de socialização em si, resultados como escolha de especialidades e inserção no mercado de trabalho, como fizeram crer Martin; Arnold \& Parker (1988).

Existem diversos estudos sobre o processo de socialização profissional na medicina, embora não sejam muito freqüentes em língua portuguesa e espanhola (especialmente oriundos de autores latino-americanos) e seja possível identificar pressupostos desta teoria no discurso de educadores de diversas matizes ideológicas. A teoria da socialização sofreu durante muitos anos um combate direto por autores de orientação marxiana que atuavam na $0 \operatorname{pas}^{29}$ (Andrade, 1979: 26).

Os estudos sociológicos clássicos sobre a socialização profissional em medicina são os de Merton; Reader \& Kendall (1957) e Becker et al. (1997).

\footnotetext{
Para uma análise de determinantes da conformação dos padrões profissionais em estudantes de Medicina no México, ver Jarillo-Soto et al. (1992).

29 Juan Cesar Garcia foi o expoente maior desta corrente. Tendo a Opas tido grande influência no processo de reflexão sobre o ensino médico em toda a América Latina e sido um refúgio para muitos intelectuais de esquerda durante as décadas de 60 e 70, muito da produção teórica por ela divulgada sobre Educação Médica possuía um viés ideológico. 0 debate entre marxianos e funcionalistas pareceu muitas vezes uma luta do bem contra o mal. Um outro exemplo pode ser visto em Frenk (1985), onde é feita uma apresentação enviesada da teoria da socialização.
} 
Robert Merton segue os passos trilhados por Talcott Parsons e desenvolve uma abordagem estrutural funcionalista, enquanto Becker foca sua atenção na perspectiva interacionista simbólica. A utilização desses dois tipos de abordagem no estudo da socialização possibilita ao estudioso do tema não apenas um melhor discernimento das diferenças entre as duas correntes, como, especialmente, de nosso ponto de vista, o conhecimento de análises indispensáveis para a compreensão do processo de socialização em medicina. Light (1988: 313) ilumina nossa reflexão ao destacar ser "notável que tantos de nós tenhamos passado mais de vinte anos debatendo quando os estudantes de Medicina são 'boys in white' ou 'student-physicians'." ${ }^{30}$

Uma primeira questão que precisa ser explicitada é a de que os estudantes estão imbuídos de um objetivo específico: tornarem-se médicos. Existe, portanto, grande motivação tanto para aprender os conteúdos específicos que possibilitam a atuação profissional como para construir sua identidade profissional, o que implicará portar-se como médico, agir como médico, falar como médico etc. Tal motivação terá igualmente grande papel na identificação de modelos e antimodelos, ou seja, na identificação daquele professor ou médico que representa um ideal do estudante como profissional médico e, da mesma forma, aquele que representará a antítese de seu ideal profissional. ${ }^{31}$

Segundo a perspectiva funcionalista, as escolas de medicina são definidas com duas funções principais: transmitir um conhecimento especializado (Moore, 1976:3) e transmitir os valores e normas que constituem o conjunto de informações padronizadas para o exercício profissional socialmente legitimado (Merton; Reader \& Kendall, 1957: 41). 0 estudante é considerado, segundo esta linha teórica, um estudante-médico, enfatizando-se assim o aspecto diretamente relacionado ao universo social em que o estudante está sendo treinado e cumprindo os ritos para ser aceito.

Já na perspectiva interacionista simbólica, “o estudante é menos um aprendiz da profissão médica e é mais um membro de um ‘grupo dominado' na faculdade de Medicina, organizando estratégias coletivas de sobrevivência institucional para o acesso com êxito ao fim dos estudos, através do que se pode designar por “argúcias acadêmicas”" (Carapinheiro, 1993: 169).

Referência nada sutil ao título dos dois principais trabalhos que polarizaram as opiniões no debate sobre a formação médica; The student physician, de Robert Merton, e Boys in White, de Howard Becker.

Para uma discussão sobre o papel dos modelos da socialização profissional, dos tipos de modelos assumidos, ver Shuval \& Adler (1980). 
Para Rennée Fox (1988), uma das autoras da citada pesquisa realizada por Robert Merton (1957), existem três diferenças fundamentais entre os dois estudos. Essas diferenças, como não poderiam deixar de surgir, refletem as diferenças de método e de pressupostos teóricos e são por ela identificadas a partir do Centro de Investigação de seus autores (Robert Merton da Universidade de Columbia e Howard Becker da Universidade de Chicago). São elas:

- as pesquisas conduzidas pelos sociólogos da Universidade de Chicago, que "eram mais psicodinamicamente orientados do que sociologicamente orientados, enfatizando o desenvolvimento pessoal dos estudantes de medicina, o impacto de suas experiências na escola médica, neles como indivíduos e o significado pessoal, consciente ou não, dessas experiências" (Fox, 1988: 88);

- "O grupo de Colúmbia estava impressionado com a extensão de como o currículo da escola médica provia formas latentes ou manifestas de 'socialização antecipada' para valores, atitudes e padrões comportamentais relevantes para o papel do médico" (Fox, 1988: 89). Já o grupo de Chicago via os efeitos da socialização da escola médica como muito mais dissociada do tornar-se médico e assumir os papéis de médicos.

- por fim, os pesquisadores de Chicago encontraram elementos de comportamento desviante na subcultura dos estudantes de medicina, embora isso não se refira a comportamentos criminosos e tão-somente a busca de estratégias coletivas, ou não, capazes de auxiliar os estudantes na superação dos obstáculos para se tornarem médicos (como a 'cola' e outras práticas não aceitáveis pela organização escolar). Os pesquisadores da Colúmbia não encontraram este componente 'desviante' em seus estudos.

0 que podemos observar é que as divergências são menos significativas que as congruências e não deveriam ocupar parcela significativa de nosso esforço para compreender a socialização profissional em medicina, salvo pela atenção que os próprios autores (e seus seguidores) conferem a elas até os dias de hoje. No caso da identificação de comportamentos 'desviantes' entre os estudantes, já são inúmeros os trabalhos, mesmo no Brasil, que apontam ser a 'cola', por exemplo, prática comum e disseminada em todos os cursos de graduação. 
Também Garcia recorda o princípio de que "os estudantes aprendem aquilo que desejam aprender, mas têm dificuldade em aprender assuntos que não lhes interessam" (Garcia, 1972: 77). Ele destaca que "é evidente que o estudante chega à escola com o desejo de observar e tratar pacientes e que esta motivação inicial deveria ser aproveitada no aprendizado. (...) 0 contato precoce com pacientes, com as funções de médico e dos serviços de saúde estimulariam seguramente o interesse do aluno por aprender outros aspectos menos chamativos".

Suas conclusões, apesar de o referencial teórico ser também discordante em relação ao de Becker e Merton, são muito semelhantes a estes quando se dedica a examinar a realidade objetiva do ensino médico em uma dimensão microssocial.

Outra característica do processo de socialização em medicina, conforme identificado por Fox, é o que ela conceituou como 'treinamento para a incerteza'. Ela identificou três tipos de incerteza para as quais os alunos são direta ou indiretamente treinados durante o curso médico:

\footnotetext{
- "As incertezas que se originam no seu domínio incompleto do enorme e rapidamente crescente conjunto de conceitos, fatos e habilidades que a moderna medicina ocidental cerca;

- as incertezas que se originam das lacunas, limitações e ambigüidades que também caracterizam o impressionante corpo de conhecimento e técnicas médicas;

- as incertezas que se originam das dificuldades para distinguir entre sua ignorância pessoal e inépcia e as próprias tentativas do conhecimento médico para esclarecer essas dúvidas. Sua condição de neófito de conhecimento e de baixa confiança em si próprio torna especialmente difícil para os estudantes discernir onde a própria ignorância deles termina e a do conhecimento médico começa. (Fox, 1989: 83)
}

A compreensão desse confuso estado de incertezas crescentes e progressivamente mais complexas com a evolução do estudante no curso médico é necessária tanto para o estabelecimento de novas estratégias de ensino como para compreender algumas das situações em que os estudantes identificam conflitos éticos envolvendo seus professores ou colegas e acabam, quase sempre, optanfo por não intervir. É preciso lidar com suas próprias dúvidas e estar preparado para ser humilhado, caso seja evidenciado que estava errado.

Carapinheiro (1993) identifica como momentos estratégicos da gestão dos comportamentos de certeza e incerteza os anos pré-clínicos, nos quais eles vão de um estado de perplexidade e incerteza total até a legitimação da incerte- 
za, quando comparam suas dúvidas com as de seus professores e desenvolvem um comportamento afirmativo de não mostrar demasiadas certezas.

Nos anos clínicos a incerteza articula-se progressivamente com o sentimento de responsabilidade. É a construção de um estado de certeza, na convicção de que é impróprio duvidar demasiadamente para se saber estar com o doente e não se sujeitar às críticas dos colegas. Então tomam corpo os elementos estruturais da conduta normativa médica, consubstanciados numa 'política de acreditar' nos princípios que organizam as condutas médicas esperadas pelos doentes e pelos seus pares. (Carapinheiro, 1993: 167-168)

Este entendimento nos permitirá, como veremos mais adiante, compreender uma outra manifestação dessa adesão aos princípios normativos da corporação médica e que tem sido identificada por diversos sociólogos como um crescimento do cinismo dos estudantes durante o curso médico.

Assim, a socialização profissional inclui mais do que habitualmente é descrito como educação e treinamento, sendo útil pensar no processo de aquisição da função em duas classes principais: 1) aprendizado direto através do ensino didático de um ou outro tipo; 2) aprendizado indireto, no qual atitudes, valores e padrões de comportamento são adquiridos como subprodutos do contato com instrutores e pares, com pacientes e com membros da equipe de saúde: "os estudantes aprendem não somente do padrão ou mesmo do exemplo deliberado; eles também aprendem - e pode ser a forma mais duradoura de aprendizado - do envolvimento contínuo naquela sociedade da equipe (staff) médica, colegas estudantes e pacientes que constituem a escola médica como uma organização social” (Merton; Reader \& Kendall, 1957: 41-42).

Esta aprendizagem indireta, não imputada diretamente às ações programadas no processo de ensino, é chamada pelas teorias pedagógicas de "currículo oculto'. 0 currículo oculto inclui desde as influências advindas dos meios de comunicação social (jornais, programas ou seriados exibidos em televisões, por exemplo) até o resultado das relações sociais estabelecidas com integrantes ou não da comunidade da área da saúde. ${ }^{32}$

É a faculdade que costuma ser identificada como elemento crucial na aprendizagem profissional, porque representa o contexto institucional no

É comum entre os autores médicos uma certa confusão entre currículo oculto e currículo paralelo. Este último constitui-se do conjunto de atividades realizadas pelos estudantes e que não constam do rol previsto e preconizado oficialmente pela instituição de ensino. São atividades 'paralelas' ao currículo oficial. 
qual se inicia a socialização. A Faculdade de Medicina é importante porque constitui não somente o ambiente onde se transmitem os conhecimentos, experiências, hábitos, atitudes e valores, mas também o meio pelo qual os membros da profissão controlam o que seus colegas serão e o nível de aprendizagem que recebem. (Coe, 1984: 234)

0 indivíduo em sua socialização profissional não é um mero objeto a ser moldado conforme as vontades e preceitos da sua futura corporação, mas também sujeito ativo desse processo, isto é, ator. Sua formação anterior, fruto de sua inserção social, constitui-se no alicerce sobre o qual sua formação profissional se dará, o que repercutirá em suas futuras escolhas profissionais e também nas suas atitudes profissionais desenvolvidas. Mas esta repercussão não deve ser entendida como 'destino', tanto devido à liberdade pessoal que ele deverá necessariamente exercer em suas escolhas profissionais, como também pela força do próprio processo de socialização profissional, que buscará uma padronização mínima de conhecimentos, valores e atitudes inerentes à sua atuação profissional.

Inseridos nessa discussão, são reconhecidos os clássicos estudos de Eron (1955) e Merton; Reader \& Kendall (1957), que indicam um aumento do cinismo e uma perda do idealismo à medida que os estudantes avançam em seus estudos.

0 cinismo costuma ser identificado como um dos efeitos da educação médica - o desenvolvimento nos estudantes de uma 'preocupação desinteressada' pelo seu paciente. Uma interpretação mais compreensiva da questão do idealismo e do cinismo é apresentada por Howard Becker, para quem "a mobilização de uma perspectiva cínica desenvolve-se estrategicamente ao longo do curso, (...) na construção de uma atitude mais preocupada com os aspectos físicos da doença e mais despreocupada com os seus aspectos sócio-psicológicos". Entretanto, para este autor, ao final do curso reaparece "um idealismo mais bem informado, na preocupação pelas responsabilidades médicas e sociais da prática da Medicina” (Becker apud Carapinheiro, 1993: 169).

Em um estudo publicado em 1993, Kottow analisou as mudanças nas atitudes éticas observadas entre 79 estudantes de medicina em três momentos diferentes de seu processo de formação. Suas conclusões corroboram as de Eron, Merton e Becker quando afirma: "a presente pesquisa confirma que durante os estudos de medicina se produz uma progressiva erosão da atitude humanista e espontaneamente crítica, sendo substituídas por um profissionalismo mais respeitoso de normas e códigos" (Kottow et al., 1993: 383). 
Suas observações reforçam a idéia da influência da socialização profissional e do currículo oculto na padronização de comportamentos e atitudes dos futuros médicos.

Matheux \& Béland (1987) procuraram abordar um aspecto que extrapolava os limites do campo profissional propriamente dito. Interessava a eles investigar se as atitudes em campos como a atividade social e política sofriam igualmente o efeito da socialização e em que medida isso ocorria. Para tal, realizaram um survey com 586 estudantes de medicina de três escolas com orientações sociais diferentes. Uma voltada para a formação altamente especializada com grande enfoque para a pesquisa biomédica, outra representando o que os autores consideram como o perfil médio das escolas norte-americanas com ênfase tanto em pesquisa e em atenção primária e medicina comunitária e a recomendação para que os alunos freqüentem as aulas de psicologia e ciências sociais e, finalmente, a terceira, que apresenta uma ênfase na abordagem biopsicossocial na assistência ao paciente e tem como disciplinas obrigatórias no curso básico a sociologia, a psicologia e a antropologia.

Assim, como efeito do processo de socialização, seria de se esperar que os alunos desta última escola tivessem atitudes e um posicionamento sociopolítico mais liberal que os demais. Embora os pesquisadores tenham controlado diversas variáveis como gênero, raça, origem geográfica, surpreenderam-se por não detectarem variações significativas entre os resultados obtidos pelos estudantes das diferentes universidades. Seu raciocínio era de que se a socialização fosse 'efetiva', os alunos das escolas promoveriam um ensino mais liberal e mais voltado para uma visão social da medicina.

Um de seus resultados significativos, embora não tenha sido explorado em suas análises por se repetir em todas as universidades, foi que os jovens negros obtiveram resultados significativos na manutenção de uma perspectiva mais social para a prática médica, menos conservadora. Para a perspectiva de análise desses autores, este fenômeno deveria ser justificado por um suposto amadurecimento dos jovens (admitindo, por conseguinte, que uma visão mais social e justa para a assistência à saúde da população reflete a imaturidade do sujeito).

lgnorando o preconceito ideológico dos autores (que embora analisem os Estados Unidos, estão radicados no Canadá), é possível encontrar na concepção de Berger \& Luckmann (1990) de socialização, e mesmo em Bourdieu (1996), hipóteses (que precisariam ser testadas) mais convincentes. 
De acordo com essas concepções teóricas, os conteúdos interiorizados durante a socialização primária, ou o capital cultural, na perspectiva de Bourdieu, estão diretamente relacionados com a inserção dos sujeitos e de seus pais na estrutura social, sendo que o conteúdo da socialização secundária se sobrepõe ao da primária, que tende a ser preservada em situações de conflito pelos conteúdos emocionais agregados. Assim, sendo os indivíduos de raça negra mais discriminados na sociedade americana, a referida tendência a aceitar uma concepção mais justa para a organização e a prática médica estaria mais coerente com eventuais conteúdos socializados por filhos de segmentos discriminados da sociedade, como os negros.

Outra hipótese, ainda relacionada a esse aspecto, é o caráter conservador da própria corporação médica e sua despreocupação concreta com aspectos sociais de sua prática. Bloom (1988: 294) chega a afirmar, após um extenso estudo sobre as reformas curriculares no curso médico nos Estados Unidos, que a "manifesta missão humanística da educação médica é pouco mais do que um pano de fundo para a missão de pesquisa que é a principal preocupação da estrutura social das instituições”. Embora esta afirmação seja extremamente prejudicial à imagem social dos profissionais médicos, parece ser amplamente reconhecido que a preocupação social não é, via de regra, uma preocupação das escolas médicas, não ultrapassando os limites da retórica. Kendall \& Reader (1988: 279-293), embora não discordem, acreditam que os objetivos educacionais relacionados à aquisição de valores e atitudes apropriados estão em foco nos dias de hoje, e creditam ao uso do Problem Based learning (PBL) as melhores possibilidades de esses objetivos serem alcançados.

\section{Socialização em medicina no Brasil: estudo antecedente}

Embora tenha sido afirmado que tradicionalmente o locus fundamental para o processo de formação profissional em medicina é a faculdade e o hospital universitário, em nossa realidade isso não é sempre verdade. Virtualmente, a totalidade dos estudantes de medicina busca, ainda durante o seu curso de graduação, estágios fora dos auspícios e controle da instituição de ensino a qual está formalmente vinculado.

Assim, conforme pesquisa realizada anteriormente por nós, todos os alunos que estavam no último ano de sua graduação haviam freqüentado um estágio desse tipo (Rego, 1994). Nesses estágios, a despeito da freqüência de outras razões (remuneração, inserção no mercado para assegurar a permanência 
no emprego após a formatura) que são apontadas por outros autores na literatura, os estudantes buscam adquirir uma maior experiência clínica. Estes estágios são amplamente aceitos e justificados pela corporação como uma estratégia válida para a aquisição daquela experiência. Ela deve ser entendida como:

a verdadeira experiência em lidar com pacientes e doenças, e o principal significado desta expressão repousa na polarização implícita com o 'aprendizado em livros'. A experiência clínica, na visão adotada para este termo, confere ao médico um conhecimento que ainda não foi sistematizado e verificado cientificamente. Não é possível adquirir este conhecimento através do estudo acadêmico - é necessário observar o fenômeno clínico e lidar com os problemas clínicos diretamente. A experiência clínica pode inclusive substituir o conhecimento comprovado cientificamente, pode ser usada para legitimar um conjunto de opções de procedimentos para o tratamento de um paciente e, da mesma forma, pode ser usada para contra-indicar alguns procedimentos que tenham sido estabelecidos cientificamente. (Becker \& Geer, 1963: 172)

Assim, é a busca pela aquisição de maior experiência clínica e a compreensão do significado da 'responsabilidade profissional' desde a perspectiva da profissão médica o que poderíamos chamar de ‘coração’ da educação médica.

A socialização profissional dos estudantes de medicina ocorre também em estágios extracurriculares; longe do controle social representado pela escola médica, ela pode estar contribuindo para uma formação na qual a 'responsabilidade profissional' e o 'ideal de serviço ${ }^{33}$ sejam 'reinterpretados' e compreendidos pelos estudantes em uma perspectiva que poderá comprometer sua futura atuação profissional do ponto de vista da ética, ainda que estritamente profissional. Este processo, como justificaremos adiante, ocorrendo longe de seu controle social, se dá em um ambiente em que a autonomia dos estudantes em sua prática chega a níveis incompatíveis com sua efetiva preparação técnica para seu adequado desempenho.

Esta experiência, conforme foi assinalado por Becker et al. (1997), só pode ser adquirida com a prática. Para estes autores, os estudantes têm uma pergunta permanentemente norteando suas reflexões: "Como posso aproveitar melhor meu tempo para preparar-me para a prática profissional como médico?”.

O conceito de ideal de serviço é oriundo da Sociologia das Profissões e representa uma das características sociológicas das profissões reconhecidas como tal. Sendo um fenômeno coletivo, não mensurável individualmente, representa o compromisso da profissão em encontrar a melhor solução técnica segundo o interesse do cliente, ainda que esta opção não seja a melhor para o profissional. Ver Goode (1969) e Larson (1977). 
Suas conclusões sobre como os estudantes respondem a esta pergunta podem ser sistematizadas da seguinte forma:

1. É importante para um médico ter experiência clínica.

2. As atividades na faculdade são boas para sua formação quando dão aos estudantes a oportunidade de adquirir experiência clínica ou dão a eles acesso à experiência clínica de seus professores; são ruins quando não fornecem nenhuma dessas coisas.

3. Um estudante está fazendo um progresso real em sua preparação para a prática quando ele pode demonstrar para si próprio e para outros que ele absorveu algumas lições da experiência clínica. (1997: 242)

A introdução do valor 'experiência clínica' na análise dos estágios extracurriculares clareou diversos pontos que até então estavam obscuros em nossa análise, como por exemplo: porque os alunos diziam que buscavam aqueles estágios 'para complementar sua formação', 'para aprender o que a faculdade não ensina', 'para aprender a medicina do dia-a-dia', 'para aprender a tratar os pacientes de verdade' e outras respostas ouvidas no estudo de campo e que pareciam não coerentes com uma realidade de pouca atenção por parte de seus supostos supervisores ou professores.

Passa a fazer sentido quando se começa a pensar nesse 'aprendizado' como busca de 'experiência clínica'. Uma experiência que é reconhecida por eles como passível de ser adquirida nos locais de grande movimento de pacientes, onde eles poderão ver não um ou dois casos de determinada doença, mas diversos; onde eles poderão ver o profissional médico em seu 'verdadeiro' local de trabalho, longe do viés que o hospital universitário cria, por ser de referência para as enfermidades mais raras e para os casos mais complexos. Este viés não conseguiu ser rompido com os convênios entre o Ministério da Educação e da Previdência e Assistência Social (MEC/MPAS) da década de 70 e muito menos com a tentativa de integração ao Sistema Único de Saúde, uma vez que todo hospital universitário tem, como vocação maior, o atendimento altamente especializado e o desenvolvimento de atividades de pesquisa.

É muito fácil constatar a presença de estudantes de medicina freqüentando estágios nos mais diversos tipos de estabelecimentos de saúde. Enganam-se aqueles que acreditam que apenas as instituições públicas e, eventualmente, as chamadas "trambiclínicas ${ }^{34}$ utilizam-se da força de trabalho de estu-

34 A expressão 'trambiclínica' é de uso corrente nos meios profissionais de saúde e refere-se às clínicas e/ou hospitais que têm o lucro como seu 'único' objetivo, com sensível prejuízo na qualidade dos cuidados na prestação dos serviços de atenção à saúde (de trambique, gíria com sentido de 'negócio fraudulento', 'não confiável'). 
dantes. Estes estágios ocorrem mesmo em hospitais e clínicas de caráter privado, localizadas nas áreas mais nobres da cidade e que estão vinculadas ao sistema de saúde complementar (empresas de seguro saúde e medicina de grupo em geral).

Os alunos atuam em consultórios (ambulatórios, emergências, salas de cirurgia, unidades de terapia intensiva, enfermarias e maternidades). Obtêm seus estágios graças à cooperação de seus professores, parentes e colegas, ou ainda através de concursos públicos e empresas de intermediação de estágios. Em um número não desprezivel de casos, a própria instituição ‘desconhece’ formalmente a presença do estudante. Nestes casos, não são fornecidos comprovantes ao final do estágio. No entanto, a corporação médica nem sempre os exige, sabedora de que muitas vezes os estágios são informais, já que em geral um de seus membros o intermediou. Mas o maior número deles é formal, obtidos através de concursos ou por seleção através de anúncios publicados em jornais de grande circulação.

Apesar do caráter formal, poucas instituições possuem algum tipo de plano pedagógico para seus estagiários, o que apenas confirma a regra. Apesar de serem formal e legalmente identificados como uma atividade complementar ao aprendizado acadêmico (Brasil, 1977) e definidos como "atividades de aprendizagem social, profissional e cultural, proporcionadas ao estudante pela participação em situações reais de vida e trabalho de seu meio, sendo realizada na comunidade em geral ou junto a pessoas jurídicas de direito público ou privado, sob a responsabilidade e coordenação da instituição de ensino" (Rezende, 1986: 131-142. Grifos meus), pouquíssimas instituições que acolhem acadêmicos de medicina como estagiários mantêm qualquer tipo de relacionamento com as de ensino.

Tampouco os Conselhos Regionais de Medicina têm avançado neste campo. A regulamentação neste tema é praticamente inexistente, apesar de o Conselho Federal de Medicina (CFM), em sua Resolução nº 663/75, determinar aos médicos "que mantenham permanente supervisão dos procedimentos realizados por estudantes de Medicina, no trato com os doentes” (CFM, 1975). Na Justificativa desta Resolução, o CFM destaca:

- que o estudante de Medicina deve iniciar sua experiência no trato dos doentes o mais cedo possivel;

- que todo estudante deve ser treinado na elaboração da história clínica, no exame do doente, no diagnóstico e no tratamento; 
- que para adquirir um conhecimento básico das diferentes técnicas e procedimentos para bem tratar as mais variadas condições clínicas, o estudante deve ter contato direto com doentes com a participação, sob supervisão, na solução de todos os problemas de saúde(...) e

- que o estudante deve ter a oportunidade de participar, sob supervisão, de atos e procedimentos médicos para atingir a sua execução num grau de eficiência e perfeição desejada. (CFM, 1975)

Esta série de ponderações do CFM demonstra sua preocupação em vincular toda experiência de aprendizado clínico dos estudantes à existência indispensável de supervisão médica. Mas as tentativas de regulamentação desta prática não se limitam ao Conselho Federal. 0 Conselho Regional de Medicina de São Paulo (Cremesp) também se manifestou, em decorrência de consulta da Associação Médica Brasileira e da Associação Paulista de Medicina, através do Parecer Consulta 625/70, (Porto et al.,1976: 544-545), declarando-se impossibilitado de ter controle direto sobre os estudantes (por não ser sua atribuição) e manifestando a intenção de responsabilizar os diretores das instituições por "acumpliar-se com os que exercem ilegalmente a profissão”. lsto apesar de reconhecer a tradição de, "desde os tempos hipocráticos, o aprendizado se fazer através de acompanhamento do professor pelos alunos”. 0 Parecer, finalmente, propõe que as atividades práticas do acadêmico sejam restritas ao ambiente da faculdade.

Posição diferente assumiu na década de 90 o Conselho Regional do Espírito Santo (CRM-ES) através das Resoluções 29/92 e 32/92 (CRM-ES, 1992a, 1992b). Nestas Resoluções, o CRM-ES considera exercício ilegal da profissão "a prática de procedimentos médicos por acadêmicos, sem supervisão direta” e, responsabilizando o diretor clínico das instituições prestadoras de serviços de saúde pela atuação dos estudantes, determina que só sejam aceitos estudantes caso exista na instituição um "programa de estágio aprovado por universidade ou escola médica de âmbito estadual, com supervisão orientada por médicos para tal". Através da Resolução 32/92 é feita a regulamentação da 29/92, destacando-se que fica determinada a comunicação formal do início das atividades de programa de estágio ao CRM-ES, sem o quê ficam considerados como estágios ilegais.

0 Conselho Regional de Medicina do Estado do Rio de Janeiro, recentemente, publicou duas resoluções que seguiram a mesma concepção daquelas do Espírito Santo. Determinou-se a obrigatoriedade de se registrar os hospitais como hospitais de ensino aqueles que abriguem estudantes e criou-se a figura 
do supervisor. Entretanto, ainda não existem elementos suficientes para avaliarmos a efetividade das resoluções.

Estes Conselhos foram os que mais avançaram na legislação, assemelhando-se à regulamentação que norteia a atuação de estudantes nos Estados Unidos. Pelos dispositivos legais em vigor naquele país, o estudante de medicina, quando desenvolve uma atividade prática, é equivalente a um leigo qualquer. 0 que o distingue é o fato de esta prática se dar em instituições vinculadas a instituições de ensino e à supervisão médica. A responsabilidade legal por seus atos é de seu supervisor direto, da escola médica e da unidade de saúde em que estes atos se desenvolvem (Kapp, 1983).

Um fato interessante, vinculado à discussão sobre os limites de responsabilidades, deveres e obrigações dos acadêmicos de medicina, são algumas tentativas de se criar um Código de Ética para eles. Esta polêmica iniciativa foi identificada inicialmente no trabalho apresentado por Porto et al. (1976: 546552) no XIV Congresso da Abem com a apresentação de um projeto de cinqüenta artigos (reapresentado no XVI Congresso da Abem, 1978). Os pontos de maior destaque dizem respeito às proibições de:

- remuneração de seu trabalho como acadêmico;

- assinar receitas ou fazer prescrições;

- fornecer atestados;

- prestar assistência médica sob sua responsabilidade.

No XVII Encontro Científico dos Estudantes de Medicina, foi apresentado para discussões um outro projeto de Código com 27 itens, de inspiração declarada no trabalho de Porto. Nele, os estudantes propõem que o "estudante não deve praticar atos médicos de qualquer natureza sem supervisão de um médico”.

Já o Conselho Regional de Medicina da Paraíba aprovou em sessão plenária a apresentação de um Código de Ética para o estudante de Medicina (CRM-PB, 1991) como sugestão "aos setores responsáveis pela graduação médica”. Na apresentação da publicação que contém o Código, seu presidente afirma que "[a criação do Código] nada mais representa senão a aceitação de suas atividades". Esta proposta não apresenta maiores diferenças em relação às anteriores. Esta publicação, com o referido Código, demonstra claramente a dificuldade que os órgãos responsáveis pela fiscalização do exercício profissional têm para lidar com a questão dos estudantes. Se por um lado os Conselhos 
sentem a necessidade de regulamentar sua atuação, por outro, não os reconhecem como estando sob sua competência. Tal fato possivelmente contribui para a situação de verdadeira anomia que caracteriza os estágios extracurriculares dos estudantes de medicina, em que a regulamentação existente é ignorada.

A maioria dos anúncios procurando estagiários de medicina, habitualmente publicados nos jornais, nos dá um indicativo importante em relação às atividades por eles desenvolvidas. Dizem, por exemplo:

"Acadêmicos de Medicina - 4º ano - com experiência em Obstetrícia"

“Acadêmicos - Plantão 24 horas - com experiência em Emergências"

"Médicos acadêmicos - Clínica Médica - pagamento de produtividade"

Como pode ser visto no primeiro reclame, procura-se um estudante do quarto ano com experiência em uma especialidade que não terá ainda concluído em seus estudos regulares na faculdade. $0 u$ seja, o mercado conhece a realidade dos estágios mais do que oficialmente as próprias faculdades admitam conhecer das atividades de seus alunos. ${ }^{35}$ De forma às vezes extremamente precoce, os estudantes, desde seu primeiro ano de curso, iniciam-se na prática extracurricular, embora seja no quarto ano que essa prática efetivamente seja mais freqüente. As emergências e unidades de terapia intensiva são os locais mais procurados pelos alunos para seus estágios (Rego, 1994).

Sabendo-se que freqüentam esses estágios, resta saber que atividades são efetivamente desenvolvidas por eles e como se dá sua supervisão. A grande maioria dos estagiários do quarto ano detém a autonomia de decidir quais exames deve solicitar para elucidar cada quadro clínico que lhe cabe resolver. Mais da metade desses alunos são também responsáveis pela decisão terapêutica para cada caso. Convém recordar que a imensa maioria desses alunos está atuando nas emergências ou pronto-socorros públicos e privados localizados na região metropolitana do Rio de Janeiro. Enquanto suas aulas práticas sob os auspícios da faculdade reservam a eles um papel de espectadores privilegiados contemplativos, em seus estágios participam efetivamente no atendimento de pacientes. Em 80\% das entrevistas realizadas com alunos desse nível, o estagiário considerava-se responsável pelo atendimento realizado. Certamente contribuía para essa convicção o fato de que, em mais de 30\% dos casos, o médico

\footnotetext{
Em conversas informais com diversos coordenadores de curso de escolas de diversos estados do Brasil, foi extremamente comum ouvir a informação de que seus alunos não faziam estágios, já que a faculdade os ocupava em tempo integral e lhes proporcionava uma formação integral. Mas a realidade dos fatos os contradiz.
} 
encarregado de sua supervisão não se encontrava no mesmo ambiente que o aluno quando este realizava seus atendimentos.

Quando os estudantes estão em seu sexto ano de curso, na iminência de se graduarem, sua autonomia é ainda maior. Atuam praticamente como se já fossem médicos, apesar de seu local preferencial de estágio ser, neste momento, as Unidades de Terapia Intensiva e Unidades Coronarianas, onde os pacientes são os mais graves e em permanente risco de vida. ${ }^{36}$ Note-se, aqui, também uma particularidade - a maioria desses estágios é oferecida em hospitais e clínicas privadas, em geral vinculados ao sistema de saúde complementar.

Portanto, por ocuparem um espaço privilegiado na formação do futuro médico, os estágios extracurriculares constituem-se num dos principais campos em que o processo de socialização se dá; em que o estudante adquire uma maior experiência clínica; assim como em que observa a aplicação prática dos valores e princípios profissionais. Assim sendo, e a despeito de todo o ideal de serviço que norteia a profissão, os estudantes estarão se habituando a um comportamento prejudicial ao seu paciente.

Tomemos como objeto de análise seu comportamento em relação ao ato de se identificar ao seu paciente. Como os hospitais e clínicas nos quais esses estágios ocorrem não são reconhecidos como hospitais de ensino, é aceitável supor que os pacientes acreditem ser atendidos por médicos e não por estudantes. Mas não apenas os estudantes não são orientados e não têm a iniciativa de se identificarem perante seus pacientes como estudantes, como é hábito de seus supervisores os chamarem de 'jovens médicos' quando estão na presença de algum paciente. Negase, assim, ao paciente, o direito de saber que não está sendo atendido por um profissional com formação técnica adequada para o desempenho daquela função.

0 quadro a seguir compara os resultados obtidos com os referentes a estudantes de medicina do Estados Unidos que foram publicados por Cohen et al. (1988). ${ }^{37}$ Nele, é possível observar que, a despeito da rígida lei contra a má prática profissional lá existente, $28,9 \%$ dos estudantes informaram não se identificar como tal ao iniciar um atendimento, bem como não solicitaram o consentimento para o atendimento. ${ }^{38}$ Entre os estudantes brasileiros entrevistados,

\footnotetext{
36 É interessante que o jargão profissional fale em risco de vida, quando na verdade trata-se de risco de morte. Mas o sentido é o de que a vida está em risco.

37 Sua pesquisa foi um survey nacional enviado pelos Correios a todos os alunos matriculados no $3^{\circ}$ ano do curso de medicina.

38 Grant (1994) discute o direito dos pacientes em recusarem o envolvimento em atividades de ensino no Reino Unido, particularmente na Nova Zelândia.
} 
por sua vez, os resultados são bem menos animadores - mesmo os alunos no quarto ano médico já se identificam como médicos em seus estágios, apesar de terem comportamento bastante diferenciado quando se trata de atendimentos na faculdade.

Quadro 1 - Proporção de Estudantes de Medicina segundo a forma como se apresentam a seus pacientes - EUA - Brasil (RJ - uma escola médica)

\begin{tabular}{|lccccc|}
\hline $\begin{array}{l}\text { Como se apresenta } \\
\text { ao paciente? }\end{array}$ & $\begin{array}{c}\text { 30 Ano } \\
\text { (EUA) }\end{array}$ & $\begin{array}{c}40 \text { Ano } \\
\text { (Br) } \\
\text { (faculdade) }\end{array}$ & $\begin{array}{c}4 \text { - Ano } \\
\text { (Br) } \\
\text { (estágios) }\end{array}$ & $\begin{array}{c}\mathbf{6}^{\circ} \text { Ano } \\
\text { (Br) } \\
\text { (faculdade) }\end{array}$ & $\begin{array}{c}\text { 6o Ano } \\
\text { (Br) } \\
\text { (estágio) }\end{array}$ \\
\hline $\begin{array}{l}\text { Explica que não é } \\
\text { médico e seu status } \\
\text { de estudante }\end{array}$ & $5.5 \%$ & $0 \%$ & $0 \%$ & $0 \%$ & $0 \%$ \\
$\begin{array}{l}\text { Apresenta-se como } \\
\text { estudante mas não } \\
\text { explica status }\end{array}$ & $60.8 \%$ & $82.5 \%$ & $16.0 \%$ & $48.8 \%$ & $20.9 \%$ \\
$\begin{array}{l}\text { Apresenta-se como } \\
\text { médico }\end{array}$ & $6.1 \%$ & $5.0 \%$ & $42.0 \%$ & $13.9 \%$ & $30.2 \%$ \\
$\begin{array}{l}\text { Não se apresenta } \\
\text { de nenhuma } \\
\text { maneira específica }\end{array}$ & $27.7 \%$ & $12.5 \%$ & $42.0 \%$ & $37.2 \%$ & $48.9 \%$ \\
\hline
\end{tabular}

Obs.: A comparação entre esses dados não pode ser feita de maneira irresponsável. 0 estudo de Cohen foi um survey, com diversas escolas médicas envolvidas. 0 estudo brasileiro foi um estudo de caso, cujos resultados não devem ser entendidos como representativos da totalidade das escolas médicas brasileiras. Todavia, considerando-se que a faculdade em questão é considerada uma das melhores de nosso país, não há elementos para supor que o quadro em outras faculdades seja muito diferente do aqui relatado, o que temos comprovado através de inúmeros contatos com alunos de todos os estados nos diversos Encontros Científicos dos Estudantes de Medicina e Congressos Brasileiros de Educação Médica que freqüentamos nos últimos 10 anos.

Fonte: Cohen et al. (1988).

A reflexão que se faz necessária, e que procuramos ilustrar até aqui com a discussão sobre como o estudante se apresenta a seu paciente, é exatamente sobre que valores são ensinados/demonstrados/sugeridos/difundidos entre e para os estudantes em seu processo de formação profissional. 
De que maneira os estudantes (re)conhecem valores da profissão como a experiência clínica, a autonomia profissional e como lidam com os dilemas resultantes dessa aprendizagem diretamente com pacientes, da interação entre um aprendiz e um ser humano, sabedor ou não de que aquele que o atende é um profissional formado, em treinamento ou um simples aprendiz? Como a Faculdade busca discutir e transmitir o comportamento ético para os estudantes? Quais são os dilemas ou as situações em que os estudantes são instados a tomarem uma decisão que envolve uma discussão moral e que argumentação ampara sua decisão? Como a faculdade de medicina (docentes, médicos assistentes, equipe de saúde) se manifesta em relação ao ensino com pacientes? Quais os cuidados e precauções são adotados para a preservação da integridade física e moral dos pacientes e para a promoção de um ambiente no qual o respeito ao paciente seja preponderante? Como o paternalismo médico ${ }^{39}$ é expresso e como se reproduz entre os estudantes? Se, como veremos mais adiante na discussão sobre as Teorias Congitivistas do Desenvolvimento Moral, todos passam necessariamente por um estágio em que a obediência a uma regra ocorre pelo temor das punições, poderá a falta de regras explícitas aplicáveis aos estudantes de medicina e estagiários em geral ser uma explicação razoável para o comportamento desses estudantes quando não estão sob supervisão estrita?

\section{Teoria da Aprendizagem Social}

Se os trabalhos em língua portuguesa sobre socialização são raros, mais ainda o são aqueles sobre a teoria da aprendizagem social. Poucos são os livros dedicados a esta formulação teórica ou que contenham capítulos a ela dedicados, assim como inexistiam, à época da redação deste capítulo, sites disponíveis dedicados a esta corrente ou à sua maior expressão contemporânea - Albert Bandura. Nem parece que ela seja considerada "como uma das principais no campo da Psicologia do Desenvolvimento” (Biaggio, 1998a: 121).

Esta teoria tem sua origem no behaviorismo norte-americano, podendo ser identificada sua primeira manifestação teórica com a "publicação do livro Social Learning and Imitation, por Miller \& Dollard (1941). Neste livro, os autores buscaram integrar as formulações da teoria da aprendizagem de Clark Hull

Sobre o paternalismo como um modelo de realizar escolhas em nome de terceiros, ainda que em seu maior interesse, ver Häyry (1998). Neste verbete, o autor classifica o paternalismo em quatro tipos: soft (brando) e hard (duro), sendo este último classificado em strong (forte) e weak (mole). 
com evidências da antropologia cultural e sociologia em um esquema explicativo do comportamento humano mais complexo" (Biaggio, 1998a: 121) e, dois anos depois, publicaram novo trabalho (Personality and Psychotherapy) introduzindo conceitos da teoria freudiana no domínio da Psicologia nos Estados Unidos.

Esta teoria tem sua fundamentação no princípio de estímulo-resposta, estudando variáveis diretamente observáveis e as relações funcionais entre elas. É considerado 'estímulo', no âmbito do behaviorismo, qualquer evento que atua sobre um organismo e 'resposta' qualquer comportamento produzido por aquele organismo. 0 'condicionamento' seria a base do aprendizado para os behavioristas. São três os tipos de 'condicionamento'/aprendizagem: o clássico, tipicamente pavloviano, configurando-se no modelo de repostas incondicionais (modelo estímulo-estímulo); o 'operante', também chamado de instrumental (modelo estímulo-resposta) pelo fato de a resposta servir como instrumento para a obtenção do reforço, e o por 'imitação de modelos', sobre o qual iremos nos deter de forma mais amiúde em breve, que é bem menos radical que os anteriores e o que foi desenvolvido por Bandura.

Dentre os conceitos tradicionais da teoria behaviorista, devemos nos ater aos relacionados com a idéia de reforço. 0 reforço positivo é aquele que, após uma resposta, aumenta a probabilidade da repetição deste evento, e o negativo é o que, quando suprimido, aumenta a probabilidade de o evento se repetir. Uma confusão freqüente entre os leigos é a distinção entre um reforço negativo e uma punição. Esta é definida como a ação que diminui a chance de um determinado evento ocorrer ou se repetir. A utilização de experimentos com cobaias é útil para esclarecer a distinção: se a retirada de um choque elétrico aumenta a probabilidade de uma cobaia pressionar uma alavanca, esta retirada é considerada um estímulo negativo. Se a aplicação do choque elétrico foi feita após uma cobaia pressionar uma alavanca, a tendência é que ela deixe de pressioná-la, configurando uma punição.

Quando Bandura começou a construir sua teoria, o fez identificando três áreas que considerou como as maiores fraquezas do behaviorismo: o número limitado de comportamentos passiveis de serem pesquisados em laboratório; o fato de as teorias behavioristas serem incapazes de considerar a aquisição de novas respostas a situações e o fato de elas lidarem com apenas um tipo de aprendizagem - aprendizagem direta, na qual o aprendiz apresenta uma resposta e vivencia as conseqüências. Bandura chama este tipo de aprendizagem de instantaneous matching e, ao discutir o aprendizado indireto, passa a refe- 
rir-se a um delayed matching quando o aprendiz apresenta um comportamento que foi reforçado e, posteriormente, reforça o mesmo tipo de comportamento.

Como veremos, Bandura construiu uma teoria que, ao agregar elementos do behaviorismo e outros do cognitivismo, possibilita um entendimento bastante harmonioso para o aprendizado decorrente do processo de socialização. Esta teoria dá grande ênfase aos processos auto-regulatórios: "Nesta abordagem, os indivíduos não são organismos meramente passivos, sujeitos a um constante bombardeio de estímulos ambientais. Ao contrário, são organismos ativos, capazes de focalizar, selecionar e organizar, dentre esses estímulos, aqueles que consideram relevantes" (Davis, 1981: 77).

Sendo reconhecida a capacidade do indivíduo de redirecionar o curso da ação, ele passa a ser visto como o principal agente de sua própria mudança, modificando, assim, o enfoque básico da teoria behaviorista tradicional. 0 reforço externo direto passa a ser considerado como apenas mais uma variável que atua no processo de aquisição de novos padrões de resposta. Outro aspecto fundamental é considerar que é possível e provável que haja uma defasagem entre a observação e a emissão da resposta a um determinado modelo.

Outro aspecto fundamental para a compreensão dessa proposta teórica é a distinção entre aquisição de uma capacidade cognitiva e o seu desempenho. Ou seja, assume-se que não há necessariamente uma correlação entre o comportamento e a capacidade cognitiva para desempenhá-lo. 0 indivíduo estabelece filtros tanto pela representação simbólica do ato em si, seja pessoal, seja social. 0 que no behaviorismo aparece como uma incorporação recente e inovadora, já vinha sendo discutida pela psicanálise há muitos anos com as relações entre ego, superego e id. Embora a discussão de Bandura não se dê nas mesmas bases teóricas, esta distinção entre capacidade cognitiva e comportamento rompe com limitações significativas desta corrente teórica e será igualmente fundamental para a discussão da teoria do desenvolvimento moral, na qual a capacidade cognitiva para o julgamento moral é que está em questão.

Assim, um determinado comportamento pode estar no repertório de capacidades do sujeito, mas, pela falta de respostas positivas ou pela presença de respostas negativas, ele pode ou não se manifestar. A expectativa das conseqüências de determinado ato ou comportamento não deriva somente da experiência do sujeito, mas pode decorrer também da observação das respostas obtidas por outros indivíduos significativos ou não para ele. 
Para Bandura, "a maioria das respostas sociais são obtidas através de indicações fornecidas por modelos. Estas respostas, contudo, vão se manifestar dependendo das condições de reforçamento em atuação no ambiente" (Davis, 1981: 85). Dessa forma, o que Bandura procura afastar é a noção de que seja necessário um comportamento de tentativa e erro, que seria potencialmente desastroso em situações como o aprendizado da natação e, em um exemplo relacionado com nosso objeto de estudo, no ensino da medicina (ensino de cirurgias, manobras de ressuscitação etc.).

Dois conceitos foram introduzidos na teoria mais recentemente: o de self-efficacye o de self-system. ${ }^{40}$ Segundo Pajares (1996: 543), estes conceitos foram formulados inicialmente por Bandura em 1977 e apresentados de forma mais elaborada em 1986, com a publicação do livro Social Foundations of Thought and Action: a social cognitive theory. Nele, Bandura, "escreveu que os individuos possuem um self-system que os habilita a exercer uma medida de controle sobre seus pensamentos, sentimentos e ações. Este sistema aloja as estruturas afetivas e cognitivas e inclui a habilidade de simbolizar, aprender de outros, planejar estratégias alternativas, regular o próprio comportamento e empreender a auto-reflexão" (Pajares, 1996: 543).

Assim, é conferido a este sistema o papel de prover mecanismos de referências e um conjunto de subfunções como percepção, regulação e avaliação de comportamento, que resultam da inter-relação entre o self-system e as fontes de influência externa do ambiente. Bandura assim situa no sujeito, em suas convicções pessoais, o elemento-chave da motivação e de seu comportamento.

Assim, o self-system ('sistema de auto-regulação') é baseado em subprocessos cognitivos: percepção, avaliação e regulação do comportamento. Esses processos, por sua vez, são baseados nos padrões para o comportamento do indivíduo e de suas estruturas cognitivas que oferecem referências para o comportamento e suas conseqüências. Esses padrões são baseados na autoobservação, 'auto-julgamento', auto-resposta e auto-avaliação.

Já o conceito de 'auto-eficácia' está diretamente relacionado aos processos anteriormente descritos. É, na prática, um julgamento de autoconfiança no qual o que está em jogo é a capacidade do sujeito de fazer algo específico e

40 Embora a palavra 'self' possa ter o sentido de 'ego', esta tradução não seria coerente com o conjunto de conceitos relacionados com a teoria. Portanto, ela deve ser entendida como um prefixo significando "de ou para ou feito pelo próprio” (Oxford, 1982: 823), o que equivaleria ao prefixo grego ‘auto', 'por si próprio'. 0 primeiro conceito não apresenta problemas com essa tradução, ficando como 'auto-eficácia', mas, para o segundo optamos por manter a expressão em inglês, embora seja tentado a usar 'sistema de auto-regulação'. 
obter o resultado desejado. É relacionado ao contexto de uma situação específica e diretamente relacionado a algum tipo de resultado. Difere do autoconceito (que também é uma espécie de julgamento, embora valorativo) pelo fato de este não ser relacionado a contextos, tarefas e finalidades específicas, sendo relacionado a questionamentos do tipo: "Como eu sou? Como eu me sinto?" (Huitt \& Hummel, 1997).

Esta proposta teórica tem amparado a discussão sobre os efeitos da exposição das crianças a imagens de violência e comportamentos violentos em filmes, videogames e programação da televisão em geral. Dessas discussões, a despeito da ênfase aqui apresentada sobre o comportamento autônomo dos sujeitos, têm resultado programas de controle dos níveis de exposição à violência entre crianças. 0 entendimento dos mecanismos de produção de comportamentos desejados, alvo de inúmeras experiências empíricas, tem fundamentado intervenções terapêuticas (por exemplo, no combate a fobias) como também orientado atuações em programas educativos que buscam a reprodução de comportamentos moralmente desejáveis.

Para nós, essa teoria é importante por oferecer explicações plausiveis e fornecer bases para o entendimento dos mecanismos diretos e indiretos da socialização. Tal qual nos referimos em relação às outras correntes teóricas, ela agrega mais elementos para nos orientar na compreensão do fenômeno de desenvolvimento da personalidade e do comportamento do indivíduo, embora não seja suficiente para negar as outras possibilidades teóricas. 


\section{3}

\section{Teoria do Desenvolvimento Moral de Jean Piaget e Lawrence Kohlberg}

O homem normal não é social da mesma maneira aos seis meses ou aos vinte anos de idade, e, por conseguinte, sua individualidade não pode ser da mesma qualidade nesses dois diferentes níveis. (Piaget apud la Taille, 1992: 12)

Já tivemos a oportunidade, até esse momento, de apresentar as reflexões de sociólogos sobre o processo de socialização, configuradas na teoria da construção social da realidade de Berger e Luckmann, aquelas originadas da psicologia behaviorista, com ênfase especial no desenvolvimento conferido por Bandura com a incorporação de elementos da educação e, conseqüentemente, uma visão mais 'palatável' do behaviorismo. Todas elas representam um caminho para explicar como o indivíduo estabelece relações com os outros indivíduos na sociedade, como determina seus princípios morais e passa a adotá-los e, finalmente, como se relaciona com outros indivíduos da sociedade tendo seus princípios morais como referência.

Recordando-nos de que é nossa intenção identificar os elementos fundamentais no processo de desenvolvimento da capacidade humana em reconhecer valores morais, julgar comportamentos e comportar-se moralmente, estabelecendo juízos de valor, escolhendo entre tantas alternativas a que seja capaz de identificar em uma determinada situação, resta ainda uma última teoria para completarmos o nosso objetivo - a teoria do desenvolvimento moral. Após nossa imersão nesta concepção teórica sobre o desenvolvimento moral, estaremos em condições de analisarmos os resultados de nossa pesquisa e refletir sobre as possibilidades educativas que podem ser apresentadas para as escolas médicas no campo da educação moral ou, como é mais habitual ser referido neste espaço social, do ensino da ética.

Piaget dedicou praticamente toda sua vida acadêmica às investigações sobre como se processa o desenvolvimento cognitivo, como se desenvolvem o 
pensamento e o conhecimento. Ele discutiu a interação entre estruturas cognitivas, biologicamente vinculadas, e a estimulação ambiental. Nesta perspectiva, identificou estágios dessa evolução, que ocorreriam em uma seqüência invariante (Biaggio, 1998a). Piaget publicou, em 1932, sua obra O Julgamento Moral na Criança, na qual argumentava que o julgamento moral evolui passando por etapas semelhantes àquelas por ele identificadas anteriormente, quais sejam: estágio sensório-motor, pré-operacional, operacional concreto e o de operações formais.

Para o correto entendimento da teoria do desenvolvimento moral de Kohlberg, é necessária uma breve revisão de seus pressupostos, que estão na teoria piagetiana ${ }^{41}$ e na filosofia de Kant.

\section{Estágios de Desenvolvimento em Piaget}

Piaget identificou, mediante a realização de inúmeras pesquisas ${ }^{42} \mathrm{com}$ crianças, quatro estágios de desenvolvimento cognitivo, conforme já assinalamos. A classificação cronológica do início e do fim de cada estágio é obviamente variável, de acordo com a evolução de cada criança, sendo as faixas etárias usualmente apontadas interpretadas como meramente indicativas. Nos dias de hoje, inclusive, é muito comum que alguns conteúdos escolares relacionados com a estrutura do pensamento característico de algumas fases sejam aparentemente antecipados, já que o estímulo ao desenvolvimento das capacidades cognitivas torna isso possível.

No primeiro estágio, que é o sensório-motor e duraria até aproximadamente os dois anos, a criança não possui capacidade de abstração e sua atividade intelectual é de natureza sensorial e motora. Já nesta fase, é enfatizada a importância dos estímulos ambientais para o desenvolvimento da criança, uma vez que estaria relacionada com a interação ambiental. Em contrapartida, Biaggio (1998a) afirma que há um limite para a atuação do ambiente, o que seria mais bem expresso quando Piaget subdivide este estágio em outros seis

A apresentação da teoria do desenvolvimento cognitivo de Piaget está baseada em Piaget (1983, 1990), Biaggio (1998a, 1998b), Duska \& Whelan (1994) e Sternberg (2000).

42 Segundo Biaggio (1998a), o método de pesquisa utilizado por Piaget foi fundamento para a crítica ao seu trabalho durante muito tempo, por não ser apoiado em bases estatísticas. Piaget estudou poucos casos durante longos períodos de tempo, tendo fundamentado seus trabalhos iniciais na observação de seus próprios filhos. Ele se baseava em suas entrevistas clínicas, mas só recentemente seus seguidores passaram a utilizar, com freqüência, métodos quantitativos. 
níveis, ${ }^{43}$ assim, ficaria manifesta a maturação progressiva das estruturas cognitivas, ainda que persistindo as mesmas características interacionistas.

Este primeiro estágio se constitui em um dos momentos mais significativos do desenvolvimento humano, no qual a criança, que inicialmente apresenta um comportamento centrado no próprio corpo e reativo ao ambiente e passa a desenvolver sua linguagem e a "descentralizar as ações em relação ao corpo próprio, em considerar este como objeto entre os demais num espaço que a todos contém e em associar as ações dos objetos sob o efeito das coordenações de um sujeito que começa a se conhecer como fonte ou mesmo senhor de seus movimentos" (Piaget: 1983: 8). Ele compara esta transformação a uma verdadeira 'revolução copernicana'. ${ }^{4}$

0 estágio subseqüente é o pré-operatório, com duração até os seis anos e, por sua vez, subdividido em dois níveis. Nesta fase, a criança já não depende unicamente das suas sensações e movimentos e passa a identificar um significante do significado, desenvolvendo assim sua capacidade simbólica. Esta fase, de vasto desenvolvimento lingüístico para a criança, caracteriza-se pelo egocentrismo (incapacidade da criança de ver-se do ponto de vista de uma outra pessoa), ${ }^{45}$ pela incompreensão da reversibilidade de fatos ou operações $(2+3=5, \operatorname{logo}, 5-2=3$; o vapor é a água em estado gasoso e pode voltar ao estado líquido), pelo animismo (atribuição de vida a seres inanimados) e antropomorfismo (atribuição de características humanas a seres não humanos).

Os dois níveis em que está dividido o estágio pré-operatório correspondem às idades até quatro anos e de quatro a seis anos. Esta subdivisão do estágio, segundo Piaget, é necessária, uma vez que "a passagem da ação ao pensamento ou do esquema sensório-motor ao conceito não se realiza sob a forma de uma revolução brusca, mas, ao contrário, de uma diferenciação lenta e laboriosa, que se relaciona às transformações da assimilação" (Piaget, 1983: 13). Assim, para o indivíduo chegar a uma semiologia, passa por um subperíodo em que as primeiras ‘funções constituintes' não estão ainda elaboradas.

43 Os níveis descritos por Piaget são: 1. Reflexo; 2. Reação circular primária; 3. Reações circulares secundárias; 4. Coordenação de esquemas secundários; 5. Reações circulares terciárias; 6 . Início do simbolismo.

44 Copérnico contradisse a teoria do geocentrismo que preconizava que a Terra era fixa e que os outros astros é que se movimentavam em torno dela. Ele desenvolve a teoria do heliocentrismo e atribui a alternância entre dias e noites à rotação da Terra em torno de seu próprio eixo.

45 Piaget realizou experiências em que, sentado à frente da criança, solicitava a ela que dissesse o que estava vendo - a criança descrevia Piaget. Solicitada a descrever o que Piaget via, a criança voltava a descrever o que ela própria via, não assumindo o ponto de vista de seu interlocutor. Verificou-se igualmente na pergunta a uma criança sobre quantos irmãos ela tinha, sendo respondido que um e, ao perguntar-lhe quantos irmãos o seu irmão tinha, a criança respondia que nenhum. 
No estágio seguinte, de operações concretas (de sete aos 12 anos), estas questões estão resolvidas para a criança e ela se torna capaz de raciocinar logicamente se tiver apoio de objetos concretos. Adquire a noção de conservação (por exemplo, que a quantidade de água transferida de um copo para outro de formato diferente mantém-se a mesma) bem como a compreensão de composição de elementos, associatividade e identidade.

0 último estágio descrito por Piaget foi chamado de estágio de operações formais, inicia-se aos doze anos de idade e caracteriza-se pela capacidade de abstração e da testagem de hipóteses. A partir dessa idade, as crianças já se tornam capazes de adotar outras perspectivas além das próprias, mesmo quando não estão trabalhando com objetos concretos. 0 exemplo que classicamente representa a capacidade da criança nessa idade é a compreensão e utilização dos princípios relacionados com a análise combinatória.

As principais críticas já elaboradas à Teoria de Piaget nos possibilitam igualmente situar um dos porquês de termos apresentado anteriormente as concepções teóricas do aprendizado social e da construção social da realidade: 0 papel e a importância atribuída ao ambiente social e seus estímulos. Embora Piaget não negue (ao contrário, afirma) o papel das influências ambientais no desenvolvimento cognitivo, ele "sustentava que são os processos maturativos internos, em vez dos contextos ou eventos ambientais, que determinam a seqüência da progressão do desenvolvimento cognitivo" (Sternberg, 2000: 380). Os estudos realizados posteriormente, especialmente aqueles relacionados com contextos culturais diferentes, demonstraram diferenças no ritmo ou na seqüência de estágios, opondo-se às predições de Piaget.

Nesta linha de desacordo na pequena ênfase atribuída por Piaget aos estímulos ambientais encontramos Lev Vygotsky. ${ }^{46}$ Este autor, embora não esteja nas referências conhecidas do trabalho de Berger e Luckmann, parece tê-los influenciado significativamente, como veremos adiante. Vygotsky "postula que o desenvolvimento procede enormemente de fora para dentro, pela internalização - a absorção do conhecimento proveniente do contexto" (Sternberg, 2000: 384), o que confere às influências sociais, em vez das biológicas, o caráter central em sua teoria. Embora Berger e Luckmann e Vygotsky estejam enfocando aspectos diferentes do 'aprendizado', compreendem este processo de maneira semelhante, a partir da internalização das realidades objetivas.

${ }^{46}$ Para maiores informações sobre divergências e convergências entre os postulados teóricos de Jean Piaget e Lev Vygotsky, ver Castorina et al. (1998). 
Outra grande contribuição de Vygotsky para a Psicologia do Desenvolvimento é seu constructo da zona de desenvolvimento proximal. Ela é considerada como "a amplitude de capacidades entre o nível de capacidade observável (desempenho) de uma criança e a capacidade latente (competência) da criança, a qual não é diretamente óbvia” (Sternberg, 2000: 384).

Para Vygotsky, o ambiente não é nunca uma realidade ótima para que o sujeito demonstre sua competência, uma vez que impõe a ele limites ao seu potencial. Uma demonstração prática da questão é a apresentação de um determinado problema para duas crianças e nenhuma delas conseguindo solucioná-lo. Uma delas, porém (ou eventualmente as duas, é claro), pode se beneficiar de instruções adicionais para achar sua solução. Vygotsky permite vislumbrarmos a possibilidade de que sejam investigados elementos além das capacidades observáveis em determinado momento.

Piaget identificou também um padrão de desenvolvimento da capacidade de julgamento moral das crianças. Seu trabalho consistiu em identificar as diferentes formas como as crianças, ao longo de suas fases de desenvolvimento cognitivo, se comportavam do ponto de vista do julgamento moral. Partiu do pressuposto de que nenhuma realidade moral é completamente inata e que "o que é dado pela constituição psicobiológica do indivíduo como tal são as disposições, as tendências afetivas e ativas: a simpatia e o medo - componentes do 'respeito' -, as raízes instintivas da sociabilidade, da subordinação, da imitação etc. e, sobretudo, certa capacidade indefinida de afeição, que permitirá à criança amar um ideal como amar a seus pais e tender ao bem de seus semelhantes.

Mas, deixadas livres, essas forças puramente inatas permaneceriam anárquicas, como afirmou Piaget introduzindo uma exposição sobre a necessidade da educação moral (Piaget, 1996). Alguns comentários se fazem necessários aqui em relação à compreensão de que, ao menos em parte, a moralidade é inata e sobre a tendência ao bem.

Ao contrário do que pode parecer em uma leitura apressada desta proposição de Piaget, este não negligencia a importância da interação social para o desenvolvimento cognitivo ou moral. Suas reflexões sobre a doutrina da autoridade moral de Durkheim conferem destaque à sua compreensão sobre a interação social no desenvolvimento infantil, como veremos a seguir. 
Durkheim, como um coletivista e, no que se refere à educação moral, um kantiano ${ }^{47}$ considera "toda moral como imposta pelo grupo ao indivíduo e pelo adulto à criança” (Piaget, 1994: 254). Para ele, existem dois tipos de sociedades: as conformistas, cuja solidariedade entre seus membros é segmentária ou mecânica; as diferenciadas pela divisão do trabalho social, caracterizada pela solidariedade orgânica.

Esta proposição de Durkheim sugeria que ele fosse propor que os sentimentos morais se apresentassem de duas formas praticamente opostas, segundo estivessem ligadas à heteronomia de um conformismo obrigatório ou à autonomia própria da personalidade, nas sociedades diferenciadas e orgânicas (Piaget, 1994: 255). Piaget aponta que, em suas outras obras, Durkheim reduz à unidade explicativa suas diferentes análises sobre a moralidade - a cooperação e a coação, sob a determinação desta. Piaget, por sua vez, entendia que esta solução não era a ideal.

De fato, Durkheim possuía uma proposta mais ampla: ele não se limitava a analisar a realidade, mas propunha uma verdadeira engenharia social, acreditando no desenvolvimento de uma sociedade baseada na solidariedade orgânica e apostando que o indivíduo assimilaria não a moral da sociedade que se apresenta, mas a daquela que é ou tende realmente a ser. Ou seja, em seu entendimento, uma sociedade baseada na solidariedade orgânica possibilitaria ao indivíduo assimilar a moral 'necessária' para o funcionamento equilibrado da sociedade.

Para a moral de Durkheim, "era preciso dar razão às grandes consciências contra a opinião reinante, quando se produzia um conflito” (Piaget, 1994: 257). Portanto, seria necessário dar razão às grandes personalidades da sociedade, ainda que não expressassem a moral da sociedade, mas uma moral desejada. Dessa forma, a sociedade avançaria e superaria os aspectos morais que essas grandes personalidades considerassem negativos para o seu desenvolvimento. É claro que o funcionamento da sociedade não se dá dessa maneira. Assim, Piaget contrapôsse afirmando a necessidade de se fazer uma escolha teórica, que considerasse

que a sociedade é una, e todos os processos sociais, incluindo a cooperação, são assimiláveis só à coação, mas então o bem se reduzirá, fatalmente, à

Kant defende a idéia de que "um dos maiores problemas da educação é conciliar sob uma coação legítima a submissão e a faculdade de se servir de sua própria liberdade. Pois a coação é necessária! Mas, como cultivar a liberdade pela coação? É preciso que eu acostume meu aluno a usufruir a liberdade pela coação, e que, ao mesmo tempo, o instrua a fazer bom uso de sua liberdade. Sem isso, haveria nele apenas puro mecanismo; o homem privado de educação não sabe se servir de sua liberdade. É necessário que, desde cedo, sinta a resistência inevitável da sociedade, a fim de aprender a conhecer como é difícil bastar-se a si mesmo, suportar privações e adquirir o necessário para se tornar independente" (Kant apud La Taille, 1996: 143). 
opinião reinante e ao uso tradicional; ou é preciso distinguir a sociedade de fato e sociedade ideal, isto é, a 'opinião' e a sociedade tal como 'tende realmente a ser', mas então somos levados, necessariamente, a distinguir a coação e a cooperação, de modo a situar os valores morais acima da razão de Estado. (Piaget, 1994: 257)

Piaget não aceitava a idéia do bem moral como algo externo ao indivíduo. Para ele, admitir que tanto o bem externo como o dever "derivam do sentimento do 'sagrado', sendo o 'sagrado' imperativo e desejável ao mesmo tempo, como a própria sociedade da qual não é senão o reflexo", como preconiza Durkheim, nos levaria a admitir que não há boas ações sem um elemento de obrigação (Piaget, 1994: 261), o que seria incompatível com uma compreensão dos indivíduos como sujeitos morais autônomos.

Se para Durkheim a autoridade e a repressão são os determinantes na formação do caráter do indivíduo, para Piaget, a obediência a regras impostas leva a um cumprimento de regras pelo temor da punição, não conformando uma expressão autônoma do indivíduo. Essas divergências ficam mais claras quando ambos abordam a questão da educação moral.

Se de um lado Durkheim admite inclusive os castigos físicos para impor o respeito à autoridade representada pelo professor que, em sua concepção, tem a missão de apresentar as regras aos estudantes; de outro, Piaget defende que o professor seja um colaborador no processo, acreditando que quanto mais as crianças forem capazes de negociar as suas regras, melhor compreenderão as regras da sociedade e mais aptos estarão para o exercício da cidadania. Assim, para Piaget, a relação com a sociedade promove o desenvolvimento moral, mas não porque ela impõe, pura e simplesmente, suas regras morais às crianças, mas porque possibilita, das inter-relações que se estabelecem, que os sujeitos reflitam sobre as regras, produzam um consenso sobre elas, levando-os, progressivamente, a um comportamento autônomo. Em relação às leis da sociedade, a autonomia consistiria "em compreender o porquê das leis que a sociedade nos impõe e que não somos livres de recusar” (Piaget, 1994: 265).

Piaget chegou a essas conclusões a partir do estudo de crianças de diferentes idades durante práticas lúdicas, como o jogo de amarelinha e de bola de gude. Destaque-se que ele se propôs a estudar o juízo moral e não os comportamentos ou sentimentos morais. Seu método tratava de, inicialmente, saber o que vinha a ser o respeito à regra, do ponto de vista da própria criança. Para isso, partiu da análise das regras do jogo social, na medida em que são 
obrigatórias para a consciência do jogador honesto. Das regras do jogo, passou para as regras morais, prescritas pelos adultos, buscando identificar a imagem que a criança faz a ela própria desses deveres. Por último, nas palavras de Piaget, "estudamos os princípios provenientes das relações das crianças entre si, e escolhemos a idéia de justiça como tema especial de nossas conversas” (Piaget, 1994: 21). Assim, identificou os seguintes estágios relativos à prática das regras dos jogos, que podem ser sistematizados, de forma simplificada, assim: ${ }^{48}$

1. Motor e individual (até os dois anos) - no qual a criança brinca sozinha em função de seus próprios desejos e hábitos motores.

2. Egocêntrico (dos dois aos cinco anos) - no qual a criança já recebe do exterior regras para o jogo, mas joga sozinha sem se preocupar em arrumar parceiros e, quando os tem, jogam cada um para si, possibilitando que o mesmo jogo tenha vários vencedores.

3. Cooperação (inicia-se por volta dos sete ou oito anos) - quando "cada jogador procura, doravante, vencer seus vizinhos, donde o aparecimento da necessidade de controle mútuo e da unificação das regras” (Piaget, 1994: 33), embora ao inquiridos sejam capazes de apresentar informações muito diferentes sobre as regras.

4. Codificação das regras (inicia-se aos onze, doze anos) - quando as regras são elaboradas às minúcias e toda a comunidade as conhece.

Estava claro para Piaget que uma coisa era a consciência sobre as regras, e outra, sua prática, ou seja, o porquê de se cumprirem as regras. Como pode ser verificado nas faixas etárias que ele sugeriu para cada fase, Piaget reconhecia uma certa defasagem entre a prática e a manifestação verbal que expresse a consciência sobre o porquê dessa prática.

0 comportamento infantil sobre a prática das regras foi classificado por Piaget em três estágios, no qual o segundo se inicia no decorrer da fase egocêntrica e o terceiro abrange do fim do estágio da cooperação ao conjunto daquele da codificação de regras, assim descritos:

1. No primeiro estágio, a regra não é coercitiva, "seja porque é puramente motora, seja (início do estágio egocêntrico) porque é suportada a título de exemplo interessante e não de realidade obrigatória” (Piaget, 1994: 34).

Mais uma vez deve ser feito o alerta que o próprio Piaget já fazia: o de que as faixas etárias e os próprios estágios são meramente descritivos, uma vez que "é cômodo, para as necessidades da exposição, distribuir as crianças em grupos de idade ou em estágios, mas a realidade se apresenta sob os aspectos de uma continuidade sem interrupção", que "nada tem de linear" (Piaget, 1994: 34). 
2. Durante o segundo estágio (apogeu do egocentrismo e primeira metade do estágio da cooperação), a regra é considerada como sagrada e intangivel, de origem adulta e de essência eterna, sendo toda modificação considerada uma transgressão.

3. No terceiro estágio, ela é "considerada como uma lei imposta pelo consentimento mútuo, cujo respeito é obrigatório, se se deseja ser leal, permitindo-se, todavia, transformá-la à vontade, desde que haja consenso geral" (Piaget, 1994: 34).

Resumindo, Piaget acreditava que a criança evolui em seu comportamento em relação às regras do ignorar regras, à autonomia, passando necessariamente por uma fase heterônoma. A autonomia, para Piaget, "se refere à liberdade do constrangimento causado pela heteronomia” (Duska \& Whelan, 1994: 21), ou seja, a compreensão das regras e sua aceitação mediante o entendimento de seus fundamentos.

0 cumprimento puro e simples das regras impostas pelas autoridades ou que não sejam baseadas no respeito recíproco não assegura uma adesão do sujeito a essas regras e, conseqüentemente, não representa uma capacidade de julgar e questionar a própria regra. Embora alguma ênfase seja dada a este aspecto da teoria de Piaget - de que o que se deve atingir é o respeito às regras - e isto seja supostamente passível de uma atribuição de uma certa apologia ao conformismo em sua teoria, na verdade, a proposta piagetiana pode ser entendida de forma rigorosamente oposta, uma vez que a autonomia e a reflexão sobre as regras permitirão seu questionamento.

Entretanto, isso não nos impede de também compreender esta evolução na compreensão das regras e de seu papel através da teoria de Berger e Luckmann, entendendo que, à medida que as crianças crescem e se submetem à socialização secundária, vão percebendo que o mundo possui diversas realidades subjetivas e diversas realidades possíveis, passando então a ter a necessidade de empreender estas negociações quanto às regras dosjogos para que seja possível jogá-los. 1sto, entretanto, não explicaria as diferentes compreensões da noção de justiça, que Piaget associou a dois tipos diferentes de respeito e, conseqüentemente, a duas morais - a da coação, ou heterônoma, ${ }^{49}$ e a da cooperação, ou autônoma.

Heteronomia: condição de pessoa ou de grupo que receba de um princípio estranho à razão, a lei a que se deve submeter. Ver Ferreira (2000). 
Também neste campo as crianças evoluem de uma concepção de justiça subordinada a uma autoridade adulta que decide ou de quem emanam as regras, na qual a punição expiatória é aceita a um equalitarismo progressivo, no qual há uma predominância da concepção de igualdade entre as crianças, até um estágio em que a idéia de eqüidade passa a fundamentar os julgamentos infantis. ${ }^{50}$ Neste processo, há um progressivo abandono da concepção de que existe uma justiça imanente, característica, segundo Piaget, das sociedades mais primitivas. Aliás, suas considerações sobre a justiça imanente mereceriam uma abordagem mais ampla, que deixaremos de fazer pelos limites que nos impomos neste livro.

Assim, como assinalou La Taille (1992: 11),

o homem é um ser essencialmente social, impossivel, portanto, de ser pensado fora do contexto da sociedade em que nasce e vive. Em outras palavras, o homem não social, o homem considerado como molécula isolada do resto de seus semelhantes, o homem visto como independente das influências dos diversos grupos que freqüenta, o homem visto como imune aos legados da história e da tradição, este homem não existe.

\section{A Teoria de Lawrence Kohlberg}

0 psicólogo norte-americano Lawrence Kohlberg deu prosseguimento aos estudos de Piaget, não apenas no que se refere à teoria em si e aos experimentos, mas também à faixa etária estudada, passando a contemplar crianças a partir dos 10 anos de idade até os 16 (Biaggio,1998b).

Assim como Piaget, Kohlberg estabeleceu em sua teoria um diálogo intenso com a de Durkheim, embora, diferentemente de Piaget, manifestasse de forma mais recorrente sua concordância com o sociólogo francês, como veremos mais adiante, quando abordarmos a ação educativa no campo da moral (Kohlberg, 1981). Embora sua teoria seja identificada como fundamentada na teoria de Piaget, este nunca se manifestou favorável à elaboração de testes psicológicos para diagnóstico/identificação/classificação do estágio de desenvolvimento em que o sujeito se encontra, preferindo sempre a utilização

50 A importância do trabalho de Piaget é inegável para todos os que se dedicam a compreender os fundamentos das ações morais dos indivíduos. Piaget foi um pesquisador cuidadoso, atento aos inúmeros problemas que seu método de investigação trazia e empreendendo ações específicas para controlar possíveis problemas dele decorrentes. A leitura de seus trabalhos deveria inspirar mais aqueles que seguem seu caminho teórico a observar cuidados semelhantes ou, no mínimo, a demonstrarem quais os cuidados relativos ao método foram observados. 
da entrevista clínica, interpretada teoricamente e usada para examinar as hipóteses existentes. Embora este fato - ter ou não um teste específico - seja motivo de divergência intensa entre piagetianos e kohlbergianos, o próprio Kohlberg só buscou a criação de um teste cerca de uma década e meia depois da formulação inicial de sua teoria (Kohlberg, 1981).

0 trabalho deste autor pode ser dividido em duas fases: a inicial, compreendendo desde a criação de sua tese de doutorado, quando elaborou pela primeira vez sua teoria, em fins da década de 50, até seus trabalhos posteriores de avaliação metodológica de sua teoria (quando suas pesquisas passaram a incluir adolescentes e adultos jovens, inclusive, indivíduos de outros países) e a do desenvolvimento e aperfeiçoamento de seu teste. Seus últimos trabalhos, como veremos ao final do capítulo, demonstravam um refinamento de sua teoria, seja reconceituando o último estágio, seja admitindo outros enfoques para o estudo do chamado domínio moral.

Kohlberg estudou, fundamentalmente, o raciocínio moral dos sujeitos. ${ }^{51}$ Sua preocupação não estava em discutir a prática moral dos indivíduos, mas sua capacidade cognitiva de avaliar, argumentar e refletir sobre aspectos morais. Sempre esteve claro para ele que a prática moral envolve outros elementos que não apenas a capacidade do indivíduo de análise cognitiva da questão, excluindo aspectos como o controle de impulsos e o caráter: "[0] que nós conceituamos como raciocínio moral é uma competência cognitiva, necessária, mas não suficiente para determinados tipos de motivação e conduta” (Kohlberg, 1981: 6).

Assim, ao estudar a capacidade de raciocínio moral, ele identificou seis estágios que classificou como seqüenciais e invariantes, relacionados com a maturidade das estruturas cognitivas (Biaggio, 1998a). Isto significa que, uma vez atingido um determinado estágio, ou seja, a capacidade de compreender e formular determinados tipos de argumentos relacionados a uma maturidade biológica, não seria possível uma regressão a estágios anteriores, uma vez que ninguém desaprenderia ou perderia uma capacidade cognitiva e, finalmente,

A totalidade dos trabalhos brasileiros neste campo utiliza a expressão 'julgamento moral' quando o sentido do texto faz-nos crer que Kohlberg teria utilizado moral reasoning. Nos dois livros originais de Kohlberg aos quais tivemos acesso, quando ele se refere a moral judgement, o faz distinguindo-o de moral reasoning, o que é bastante coerente com a perspectiva cognitivista (Kohlberg, 1981: 4). 0 Oxford American Dictionary (1982) define reason como "um motivo ou causa ou justificação de algo; a habilidade de pensar e entender e formular conclusões; bom senso ou juízo, o que é certo ou prático ou possível”. Embora, a rigor, a tradução por julgamento moral' não deva ser considerada como errada, e reflita o enfoque de Kohlberg em seus últimos trabalhos, entendo que a tradução ideal para moral reasoning seja 'razoamento moral' ou 'raciocínio moral', entendido razoamento como "raciocinar; defender, advogar uma causa" e raciocínio como "ato ou efeito de usar a razão para conhecer, para julgar a relação das coisas; deduzir razões” (Ferreira, 2000), optamos por “raciocínio moral' por considerá-la a expressão que mais enfatiza os referenciais cognitivos do autor. 
que esta capacidade de raciocinar possui um seqüenciamento que poderíamos tornar mais claro comparando-o aos degraus de uma escada - é necessário atingir um degrau para passar ao outro, não sendo possivel 'pular' um degrau ou estágio.

Antes de apresentarmos os seus estágios de desenvolvimento moral, é necessário que apresentemos dois de seus pressupostos, que influenciarão tanto sua definição de estágios como o desenho de seus testes. Em primeiro lugar, ele acredita na universalidade dos princípios morais, o que significa crer que, independentemente do povo ou de suas culturas específicas, existe um conjunto de princípios morais que são aceitos como válidos. 0 outro é que ele atribui uma hierarquia valorativa à seqüência de estágios, sendo que ele considera 0 sexto o melhor (Kohlberg, 1981).

Estas duas premissas influenciam decisivamente toda sua obra, pois ela pressupõe um ideal a alcançar e este ideal está configurado na aceitação de um princípio universal de justiça definido por ele - que o fez, obviamente, seguindo a sua compreensão de justiça, que por sua vez foi determinada por sua formação acadêmica e sua cultura, em seu sentido mais amplo. Ou seja, este princípio é definido por Kohlberg como universalizável. Mas deixemos as observações críticas sobre a teoria para mais adiante e passemos para a definição dos estágios, que faremos tendo como principal referência uma tabela elaborada por ele próprio, na qual é apresentada uma visão geral e resumida dos seis estágios divididos em três níveis, identificando o que é certo em cada estágio, as razões para fazer o que é certo e a perspectiva social do estágio (Kohlberg apud Power et al., 1989: 8-9).

Os três nívei ${ }^{52}$ foram chamados de 'pré-convencional', 'convencional' e 'pós-convencional ou baseado em princípios', sendo que cada um deles possui dois estágios. Em um estudo posterior, Kohlberg identificou um sétimo estágio, chamado de $4 \frac{1}{2} 2$, que apresentaremos ao final desta descrição:

- Nível 1 - Moralidade pré-convencional

Estágio 1: moralidade heterônoma - chamados por muitos autores de 'estágio de autoridade-punição'. Nele, o que é certo é evitar infringir as regras garantidas pela punição. Verifica-se a obediência para garantir o próprio bemestar e evitar-se o dano físico a pessoas ou propriedades. A razão para fazer o que é certo é o medo da punição e o poder superior das autoridades. Evitar a punição e obedecer ilimitadamente são os valores em si mesmo. 0 indivíduo tem um ponto de vista egocêntrico, não considerando os interesses de outros

Notemos que a classificação de Kohlberg parte de níveis a estágios, enquanto Piaget tinha uma estrutura inversa, de estágios em níveis dentro desses estágios. 
ou que eles diferem dos atores, não relacionando dois pontos de vista. As ações são consideradas tão-somente pela perspectiva das conseqüências físicas.

Estágio 2: individualismo - é um estágio de propósitos instrumentais, egoísticos e de trocas. 0 que é considerado correto neste estágio é qualquer coisa que atinja os interesses próprios (pessoais) da pessoa, permitindo que os outros façam a mesma coisa. 0 certo também pressupõe um senso de eqüidade em termos de trocas iguais entre partes, por acordos. Por exemplo: "o que é bom para mim" e "o que você fizer para mim eu farei para você". As razões para fazer o que é certo é atingir suas necessidades, embora reconheça que os outros têm seus interesses também. Esta é uma perspectiva individualista concreta e situacional, logo, o que é certo é sempre relativo - dependendo sempre da situação concreta e dos interesses pessoais que estão em jogo.

- Nível 2 - Moralidade convencional

Estágio 3: expectativas interpessoais mútuas, relacionamentos e conformidade interpessoal. 0 que é certo é o que geralmente é esperado por pessoas próximas ao indivíduo ou o que pessoas esperam das pessoas em seu papel como filho, irmão, amigo etc. 'Ser bom' é importante e significa ter motivos bons, demonstrando preocupação com os outros. Também significa manter relações mútuas, como confiança, lealdade, respeito e gratidão.

A perspectiva é a do indivíduo em relação com outros indivíduos, atento a sentimentos compartilhados, acordos e expectativas que têm primazia sobre outros interesses individuais, não considerando ainda a perspectiva de um sistema generalizado.

Estágio 4: sistema social e consciência - envolve uma preocupação pela ‘manutenção' da sociedade e uma orientação consciente na qual o que uma pessoa faz está de acordo com seus deveres e contribui para o bem-estar do grupo inteiro, instituição ou sociedade. 0 certo é definido em termos do que mantém suavemente o funcionamento da sociedade e que evita uma 'quebra' do sistema se todos fizerem isso. As leis devem ser apoiadas exceto em casos extremos nos quais elas entrem em conflito com outros deveres sociais fixos. Neste estágio, o indivíduo leva em consideração o ponto de vista do sistema, que define papéis e regras. As relações individuais são consideradas em termos de seu lugar no sistema.

- Nível 3 - Moralidade pós-convencional ou baseada em princípios

Estágio 5: contrato social ou utilidade e direitos individuais. Neste estágio, o indivíduo mostra-se atento ao fato de que as pessoas possuem uma 
variedade de valores e opiniões, e que a maioria dos valores e regras são relativas ao seu grupo. Estas regras devem ser normalmente apoiadas, mas no interesse da imparcialidade $\mathrm{e}^{53}$ e porque elas são parte do contrato social. Alguns valores e direitos não relativos, como vida e liberdade, entretanto, devem ser apoiados em qualquer sociedade e a despeito da opinião majoritária. Neste estágio, as razões para se fazer o que é certo repousam em um senso de obrigação à lei por se configurar em um contrato social que implica fazer e conformar-se, pela lei, ao bem-estar e proteção de todos os direitos individuais. Existe um sentimento de compromisso contratual, livremente assumido para a família, amizade, confiança e obrigações de trabalho, demonstrando uma preocupação relacionada ao fato de que as leis e deveres estejam baseados em um cálculo racional de utilidade global, 'o melhor para o maior número de pessoas'.

Neste estágio, a perspectiva fundamental é a de considerar primeiro as necessidades da sociedade, em que o indivíduo racional mostra-se atento aos valores e direitos primeiro para contratos e acordos sociais. Ele integra perspectivas por mecanismos formais de acordos, contratos, objetivos imparciais e obrigações processuais. Considera tanto os pontos de vista morais como legais, reconhecendo que eles, às vezes, estão em conflito e considerando isso difícil de conciliar e integrar.

Estágio 6: é o estágio dos princípios éticos universais. 0 que é certo está de acordo com princípios éticos escolhidos pelo próprio indivíduo. Leis específicas e acordos sociais são válidos porque eles estão baseados nestes princípios. Quando a lei viola um desses princípios, o indivíduo age de acordo com o princípio. Os princípios aqui referidos são os princípios universais de justiça: a igualdade e o respeito pela dignidade dos seres humanos como pessoas individuais. 0 indivíduo faz o que é certo baseado na convicção, como ser racional, da validade dos princípios morais universais e no seu compromisso pessoal com eles. Na proposição de Kohlberg, neste estágio, o indivíduo racional reconhece a natureza da moralidade e que as pessoas são fins em si próprias e que devem ser tratadas como tais.

0 chamado estágio $4 \frac{1}{1} 2$ foi uma 'descoberta', fruto de pesquisas que se seguiram ao seu trabalho no doutorado, com o mesmo método, no qual Kohlberg encontrou estudantes universitários apresentando uma aparente regressão moral (teriam passado do estágio 4, de moralidade social, para o estágio 2, de egoísmo instrumental). A possibilidade desta regressão contrariava toda a estrutura de

A busca da imparcialidade é motivada pela necessidade de se tomar decisões fundamentadas no interesse maior do grupo, quando ser imparcial torna-se uma necessidade objetiva. 
sua teoria que, como vimos, pressupõe uma progressão permanente ou, no mínimo, um estacionamento em um dos níveis, representando, portanto, um sério problema de método ou da própria teoria. Reanalisando os casos em questão, Kohlberg admitiu "uma fragilidade em nossa habilidade no método clínico para lidar com indivíduos que estejam em estágios de transição”(Kohlberg, 1981:2). Este fato, e a solução teórica dele, com a criação de um estágio de transição caracterizado por ser altamente relativista, egoísta e marcado pelo cepticismo, demonstrou também uma fragilidade teórica não admitida - a existência de estágios intermediários no desenvolvimento, em que hora prevaleceria um determinado modo de raciocínio moral e, em outras situações, outra. Outra possibilidade, também bastante razoável, para a explicação sobre os estágios intermediários, seria abandonarmos a imagem da evolução "em degraus de escada” e adotarmos a imagem de uma "rampa", onde a passagem de um estágio a outro seria menos abrupta e mais dinâmica. No entanto, a solução definitiva dada por Kohlberg foi, como já observamos, o desenvolvimento de um teste específico que, pontuando respostas a dilemas, classificasse o individuo de acordo com a forma predominante de seu raciocínio moral.

Mais tardiamente, em um de seus últimos trabalhos publicados (Kohlberg et al. apud Rest et al, 1999: 13), Kohlberg reconheceu que seus estágios são limitados ao escopo da justiça e redefiniu o estágio 6 para tornar-se "respeito por pessoas", no qual ele tentou incluir o princípio da benevolência ${ }^{54}$ junto ao princípio da justiça. Esta foi uma tentativa de ampliar o escopo de moralidade coberta por seus seis estágios, uma vez ter sido apontado por vários filósofos morais a insuficiência do princípio da justiça como balizador do raciocínio moral. (Rest et al., 1999).

Um dos problemas da teoria de Kohlberg é apontado como uma decorrência da realização de inúmeras pesquisas utilizando-se tanto o teste de Kohlberg como o Defining lssue Test (DIT, de agora em diante) de James Rest: a falta de dados empíricos para os estágios 5 e 6 . Ou seja, nos diversos estudos realizados que buscaram classificar os sujeitos nos vários estágios de desenvolvimento moral, praticamente não foram encontrados indivíduos que fossem classificados nos estágios relativos ao pensamento pós-convencional. Esta falta de evidência empírica, entretanto, não levou a um questionamento sobre a “justiça como valor universal”, apesar de Kohlberg ter retirado o estágio 6 de

\footnotetext{
No original "benevolence". Tanto pode ser entendido como benevolência, no sentido de tender a fazer o bem ao outro, como no de caridade. Devido ao uso tradicionalmente religioso ao termo caridade como equivalente a amor ou mesmo a amor cristão, optamos por benevolência.
} 
seu sistema de escore e de Rest ter apresentado uma nova proposta de classificação, na qual a justiça continua se apresentando como princípio estratégico na avaliação.

Uma outra abordagem crítica à definição dos estágios de pensamento pós-convencional pode ser revelar também uma certa 'armadilha' retórica para seus críticos: ao explicitamente definir seu estágio 6 como sendo o de incorporação de princípios universais de justiça, implicitamente ele rechaça críticas à aceitação deste universalismo. Neste caso, aqueles que se manifestem contrários ao universalismo devem provavelmente enquadrar-se no máximo no estágio 5, não tendo ainda a capacidade cognitiva para compreender as razões que fundamentam o estágio 6 . Com o estabelecimento dessa hierarquia de valores e de modos de raciocínio moral, sua aceitação implicaria na aceitação dos valores por ele definidos como universais. ${ }^{55}$ Daí a preocupação de autores católicos como Duska \& Whelan (1994), que buscam identificar, em cada estágio, uma reação do indivíduo à necessidade de Deus e da forma como estabelece sua relação com Ele e com a lgreja, concluindo que "se o mais elevado nível de raciocínio moral é o nível de princípio, se os princípios mais elevados são a justiça e o amor e se justiça e amor podem vir somente de uma escolha livre, então dificilmente se encontrará uma afirmação mais coerente de tais princípios do que aquela expressa no Novo Testamento" (1994: 102).

Estes autores também questionam, citando trabalhos de Kohlberg, que o sexto estágio seja efetivamente a última etapa do desenvolvimento moral. Preconizam um novo estágio, que seria fundamentado na resposta à pergunta que ficaria no estágio 6: "Por que meu comportamento deve ser moral?". Sua resposta levaria o indivíduo a escolhas existenciais - adequar o raciocínio moral à ação moral (Duska \& Whelan,1994: 9-10). Está claro que esta proposição não tem respaldo na teoria de desenvolvimento moral de Kohlberg, que, como afirmamos, não a concebeu fundamentado na ação moral, mas no raciocínio moral. Em contrapartida, em cada estágio foram apresentadas "as razões para fazer o que é certo", que de nenhuma forma devem ser compreendidas como as razões pela qual o indivíduo agiu ou agirá. Existem diversos outros fatores agregados e relacionados com a ação moral, na qual o raciocínio é necessário mas não suficiente, como já havíamos assinalado.

Nosso argumento foi na mesma direção da opinião de Popper sobre o freudismo e o marxismo, de que “não são teorias científicas porque nunca poderemos provar que são falsas, isto é os adeptos sempre podem dizer que são os opositores, seja na ilusão libidinal e que, por razões psicanalíticas, recalcam a psicanálise, ou na ilusão de classe que os faz desconhecer o verdadeiro motor da história” (Morin, 1996: 39). Nesta perspectiva, a teoria de Kohlberg com o seu estágio 6 também não o seria. 
0 próprio Kohlberg assinalou que o escopo de suas pesquisas ao longo do tempo havia se modificado "do estudo da moralidade limitada ao estudo do desenvolvimento moral, para se restringir ao estudo do julgamento moral (e sua ação correspondente) limitado ao julgamento cognitivo-estrutural do julgamento moral configurado nos julgamentos de justiça”, reconhecendo, todavia, "que o domínio moral é vasto e diverso, e nenhuma abordagem à sua conceitualização irá exauri-lo ou explicar sua variabilidade" (Kohlberg apud Rest et al., 1999: 9). Convenhamos que se, quase trinta anos depois de ter publicado seu primeiro trabalho sobre o tema, ele precisou fazer esta afirmação em um livro que discutia os consensos e divergências sobre sua teoria, no mínimo seu posicionamento não era claro até então, embora o mais provável é que ele próprio tenha se convencido de que não era possível limitar os estudo do domínio moral apenas pelo julgamento moral. Gilligan, ${ }^{56}$ ex-aluna e colaboradora de Kohlberg, afirmou que sua teoria “era muito cerebral, deixando de considerar o 'coração' da moralidade” (Rest et al., 1999: 10). Rest e colaboradores referem-se a quatro processos que compõem o domínio da psicologia da moral: sensibilidade moral, julgamento moral, motivação moral e caráter moral, que eles utilizarão para a construção de sua proposta teórica.

\section{A Distinção entre Convenções Sociais e Conceitos Morais}

Elliot Turiel introduz na discussão sobre desenvolvimento moral uma distinção entre o que é parte do domínio das convenções sociais do que é do domínio moral. Esta distinção, embora não aceita por alguns estudiosos deste campo do conhecimento (Rest et al., 1999), é, ao nosso ver, indispensável para o entendimento do desenvolvimento moral, especialmente para a compreensão das possibilidades de aplicação na educação.

Seu entendimento é o de que

desde uma idade relativamente baixa, as crianças participam de grupos sociais e de organizações sociais. No processo dessas interações, as crianças desenvolvem uma orientação sociológica ${ }^{57}$ através da qual elas constroem conceitos de cultura e de organização social. Um aspecto central da interação

Pela importância das críticas de Gilligan, deixamos para apresentá-las, com maiores detalhes, adiante.

No original, "sociological orientation". Entendemos que o autor se refere ao desenvolvimento da capacidade de refletir sobre aspectos culturais e sociais, comparando-o com a disciplina sociologia - estudo das sociedades e suas instituições. 
em sistemas sociais é a regulação normativa refletida nos comportamentos convencionalmente compartilhados; como parte de seu entendimento da organização social, as crianças desenvolvem conceitos de convenções sociais. Através de sua interação social elas também desenvolvem julgamentos morais, que são prescrições sobre comportamento. (Turiel, 1980: 69)

Sua abordagem também é considerada como estrutural e desenvolvimentista porque se baseia na análise da organização do pensamento e da ação e na transformação que as estruturas sofrem no desenvolvimento. Turiel entende que a construção de conceitos sociais se dá formando padrões organizados, fruto da interação do indivíduo com o ambiente. 0 desenvolvimento moral não é, para Turiel, um processo de internalização de comportamentos socialmente aceitáveis ou de valores culturais, mas é visto como a construção dos conceitos de certo e errado e de justiça, como resultado da interação com o meio social.

É cada vez menos freqüente que educadores defendam a transmissão pura e simples do conhecimento. A análise teórica que a teoria piagetiana sobre o conhecimento trouxe para este campo faz com que a maioria dos educadores recuse a idéia de que algo, e especialmente valores, possa ser internalizado de forma acrítica, duradoura, sem uma reflexão do indivíduo sobre essas questões. A ressalva de Turiel que assinalamos no parágrafo anterior deve ser vista como uma crítica às teorias clássicas da socialização e, possivelmente, a alguns modelos educativos baseados na transmissão heterônoma de valores. No Brasil, desde a divulgação dos trabalhos de Paulo Freire, especialmente o seu livro Pedagogia do Oprimido, que obteve grande repercussão acadêmica em nosso país e no exterior, aquela concepção de aprendizagem não é bem aceita nos meios acadêmicos. 0 que precisamos assinalar, na observação de Turiel, é que de fato é a interação com o meio social que possibilita o desenvolvimento moral, entretanto, é inegável que o meio onde o indivíduo está inserido também influirá na escolha de seus valores. Assim, o sujeito receberá, desde a socialização primária, influências de seus pais, professores, amigos etc. que reforçarão nele a importância de determinados valores, bem como o informarão das regras da vida em sociedade, com seus valores implícitos. Como veremos mais adiante, quando farei a proposta de distinção entre desenvolvimento moral e adesão a valores específicos, a opção por este ou aquele princípio moral não está relacionada com a capacidade de raciocínio moral do indivíduo.

Turiel apóia-se nos trabalhos do sociólogo Max Weber para diferenciar convenção social de moral. Ele identificou três categorias de ação social: costu- 
mes, convenções e ética, sendo que os costumes não possuem o aspecto de 'ordem legitimada' que as convenções possuem. Assim, ele faz a distinção entre julgamento moral e outras formas de julgamentos sociais, especialmente dos julgamentos baseados nas convenções do sistema social. Em seu entendimento, as convenções sociais distinguem-se da moralidade por não serem estruturadas por um entendimento conceitual de justiça (Turiel, 1980).

Turiel, em seus primeiros estudos (1980), seguindo a tradição da psicologia cognitiva estrutural-desenvolvimentista de buscar identificar estágios para categorizar as diferenças observadas no desenvolvimento, também identificou os seus, neste campo. São sete níveis que demonstram a percepção dos conceitos socioconvencionais:

Quadro 2 - Principais mudanças nos conceitos socioconvencionais

\begin{tabular}{|llc|}
\hline Nível & \multicolumn{1}{c}{ Descrição } & ldades Aproximadas \\
\hline 1. & Convenção como descritiva da uniformidade social & $6-7$ \\
2. & Negação da convenção como descritiva da uniformidade social & $8-9$ \\
3. & Convenção como afirmação do sistema de regras & $10-11$ \\
4. & Negação da convenção como sistema de regras & $12-13$ \\
5. & Convenção como mediada pelo sistema social & $14-16$ \\
6. & Negação da convenção como padrões da sociedade & $17-18$ \\
7. & Convenção como coordenação de interações sociais. & $18-25$ \\
\hline
\end{tabular}

Fonte: quadro elaborado pelo autor.

Mas Turiel abandona posteriormente a tradição de estagiamento e concentra suas análises nas três estruturas de conhecimento social que, a seu ver, estão compreendidas no raciocínio moral: o pessoal, o convencional e o moral ou, como irá referir mais comumente, os três domínios (Sapiro, 2000).

0 domínio pessoal é a área de desenvolvimento social na qual são construídos conceitos pertencentes ao self; é circunscrito a ações cujas conseqüências afetam principalmente o sujeito, sem que isso resulte em quebra de ordem social ou injustiça a outros; esse domínio é definido como a área de prerrogativa pessoal. 
0 domínio convencional refere-se à área na qual são elaboradas as normas de organização social compartilhadas pelo sujeito com o grupo, as quais são arbitrárias e contingentes à sociedade nas quais se desenvolvem, servindo basicamente para normatizar as ações sociais.

0 domínio moral abrange conceitos derivados da necessidade de justiça e bem-estar social ou individual. Os conceitos morais derivados desse domínio dizem respeito às conseqüências intrínsecas das ações avaliadas. Esta área compreende princípios considerados universais, visto que quase todas as sociedades têm padrões para avaliar justiça com base nas conseqüências intrínsecas das ações. (Sapiro, 2000: 12)

Em suas publicações mais recentes (Turiel, 2002, por exemplo), a discussão sobre um eventual estagiamento evolutivo não é mais sequer mencionada, conferindo-se toda atenção aos processos de desenvolvimento da capacidade de julgamento social e moral.

\section{Uma Abordagem Neo-kohlbergiana}

Recentemente, em 1999, James Rest, Darcia Narvaez, Muriel Bebeau e Stephen Thoma, professores do Centro de Estudo do Desenvolvimento Ético da Universidade de Minnesota, nos Estados Unidos, publicaram um livro onde sistematizam as críticas mais recorrentes e consistentes à teoria kohlbergiana e desenvolvem, tendo as críticas como referência, o que denominam uma “abordagem neo-kohlbergiana” (Rest et al., 1999). Esta 'nova abordagem', embora não negando toda a sua origem kohlbergiana, repensa e desenvolve uma nova proposta teórica para o problema do desenvolvimento moral do ponto de vista cognitivo.

É preciso que se entenda, antes de qualquer coisa, que esta proposta está fundamentada nos resultados obtidos por inúmeros pesquisadores que utilizam o DIT como teste que mede o desenvolvimento moral do indivíduo. Entre as diferenças deste teste para o teste elaborado por Kohlberg, talvez a mais significativa seja o fato de ser mais simples de ser aplicado. Esta simplificação possibilitou que um maior número de pesquisadores o utilizasse e buscasse seu aperfeiçoamento, num típico exemplo de racionalização científica. Enquanto o de Kohlberg dependeu por muito tempo de que as pessoas fizessem um curso específico para que pudessem aplicá-lo, por ser muito subjetivo, o de Rest é um teste objetivo no qual não é atribuível ao entrevistador o papel de provocar 
interferências nas respostas, conferindo assim a este último grande poder de replicação e de comparação entre resultados. Lind, ${ }^{58}$ por sua vez, os classifica como "testes que avaliam preferências e não desenvolvimento moral ou capacidade cognitiva de raciocinar” (Lind apud Rest et al., 1999: 109).

Como um breve resumo das principais propostas teóricas propugnadas por Rest e seus colaboradores, compativel com os limites deste trabalho, diríamos que estes autores:

- Não aceitam a definição de Kohlberg das estruturas cognitivas em termos de operações de justiça; embora mantenham sua noção de que as estruturas de julgamento moral são ativamente construídas pelos indivíduos.

- Reconhecem as limitações da teoria dos seis estágios de Kohlberg e afirmam que:

$\checkmark$ o julgamento moral não é o único componente psicológico do desenvolvimento moral em geral;

$\checkmark$ existe a necessidade de se estabelecer estágios intermediários;

$\checkmark$ a ênfase de Kohlberg na justiça não é um modelo aplicável em qualquer situação, lidando preferencialmente com a moralidade de relações não próximas;

$\checkmark$ os dilemas de Kohlberg não cobrem todo o domínio da moralidade.

- Não definem o pensamento pós-convencional como partidário de nenhuma corrente filosófica específica, ao contrário de Kohlberg, que é partidário da teoria de Kant e Rawls.

- Adotam o conceito de esquemas, o que Kohlberg chamava de estágios, reduzindo-os para três.

Estes autores creditam a Barlett (apud Rest et al., 1999) ${ }^{59}$ pelo uso do "termo 'esquema' para se referir a uma estrutura geral de conhecimento, residindo na memória de longa duração, que seria invocada (ou 'ativada') por configurações de estímulos atuais que se assemelham a estímulos prévios” (Rest et al., 1999: 136). A Teoria do Esquema se preocupa com a aplicação de

\footnotetext{
58 Lind, por sua vez, desenvolveu um outro teste, o Moral Judgement Test, que busca verificar não apenas a decisão do indivíduo ao dilema do teste, mas sua capacidade de argumentação pró e contra sua opção.

$59 \quad$ A Study in Experimental and Social Psychology (Barlett apud Rest et al., 1999).
} 
conhecimento prévio genérico organizado para a compreensão de informação nova. Um esquema é, portanto, uma estrutura cognitiva que consiste na representação mental de algum fenômeno de estímulo, inclusive as relações entre os elementos. Os esquemas morais podem ser entendidos, portanto, como o acúmulo de experiências de um indivíduo, resultado de sua experiência de vida. Para esses autores, são os esquemas morais, em conjunto com as bases explicativas do desenvolvimento moral, a melhor forma de se explicar o processo de julgamento moral, do ponto de vista cognitivo.

\section{A Abordagem de Carol Gilligan}

Entre as críticas mais significativas à teoria de Kohlberg, além dessas já enunciadas, está a elaboração teórica de Carol Gilligan. Esta estudiosa do desenvolvimento moral apresentou, em seu já clássico livro, In a Different Voice: psychological theory and women's development (Gilligan, 1998 - 1a Edição em 1982), uma crítica à teoria kohlbergiana com uma abordagem pela perspectiva feminista. Sua crítica está fundada nas diferenças da inserção social das mulheres, sua socialização primária e secundária que teriam sido negligenciadas tanto por Piaget como por Kohlberg. Segundo sua posição, foram os séculos de construção social da identidade feminina submissa ao homem, sem a possibilidade de ter sua vontade, desejos e raciocínio socialmente legitimados e reconhecidos, que foram negligenciados, tendo sido adotada apenas a perspectiva masculina na construção daquelas abordagens teóricas.

Como um exemplo de sua abordagem crítica, tomemos o argumento de Piaget de que as crianças aprendem o respeito às regras necessárias para o desenvolvimento moral através da prática de jogos com regras e que foi complementado, por Kohlberg, com a afirmação de que este aprendizado é mais efetivo através das oportunidades para assumir papéis sociais no curso da resolução das disputas. Gilligan aponta que os jogos tradicionalmente femininos, como pular corda e a amarelinha, são jogos em que cada um tem a sua vez de jogar e em que a competição é apenas indireta, ou seja, o sucesso de um não implica necessariamente a derrota do outro. Dessa forma, a necessidade de arbitragem é menos provável que venha a ser necessária. "De fato, a maioria das meninas prefere encerrar o jogo quando ocorre algum desentendimento, ao invés de elaborar um sistema de regras para resolver a disputa. Meninas condicionam a continuação do jogo à conti- 
nuação das relações” (Gilligan, 1998: 10). Outro aspecto observado por ela em relação às diferenças entre jogos infantis é que os jogos tradicionalmente masculinos ensinam tanto a independência como as habilidades organizativas necessárias para a coordenação de grandes e diversos tipos de grupos sociais. Participando em situações de competições controladas e socialmente aceitas, os meninos aprendem a jogar com inimigos e competir com amigos, tudo de acordo com as regras do jogo. Em contraste, as meninas tendem a brincar em grupos menores, muitas vezes com a melhor amiga, e em espaços privados. Negligenciar estes aspectos, segundo Gilligan, significa ignorar as diferenças fundamentais na socialização segundo gênero e privilegiaria as possibilidades de desenvolvimento que a alternativa mais comum entre meninos possibilita.

Essas são algumas das observações que Gilligan faz para assinalar as diferenças na socialização entre meninos e meninas e já sugerindo algumas das conseqüências sociais que surgem como resultado deste modelo educativo. À afirmação de Piaget de que os meninos são mais preocupados com as regras e as meninas com as relações, Gilligan afirma que estas situações levam a diferenças significativas no desenvolvimento moral de ambos: enquanto meninas se preocupariam mais com relações e se comportariam mais de acordo com a necessidade de cuidados, os meninos desenvolveriam um senso mais apurado de justiça. Notemos que Gilligan, neste momento parece estar, de fato, mais incomodada com o fato de a escala de desenvolvimento moral possuir valor agregado, o que gera estágios melhores do que outros e, portanto, atribuir um valor maior ao que seria o estágio possível de ser alcançado pelos homens do que aquele no qual seria classificado este raciocínio cuidador das mulheres.

Afirmar que existem pessoas mais bem desenvolvidas que outras, formas de raciocínio moral melhores que outras e homens melhores que mulheres, por serem mais desenvolvidos, é inaceitável para a perspectiva feminina, e com toda a razão. Trata-se de uma perspectiva discriminatória e preconceituosa. Por estarem mais preocupadas com as relações do que com as regras devido às experiências sociais que experimentaram desde a infância e pelos valores que Ihes são informados como os mais importantes e melhores, durante a socialização, as mulheres estariam mais voltadas à acomodação de conflitos e ao cuidado com o outro do que a resolvê-los pela convicção sobre este ou aquele princípio moral. 
Por um lado, a ênfase atribuída ao papel dos jogos é absolutamente pouco relevante nos dias de hoje, não podendo mais ser usada como argumento principal, senão para comparar com as origens teóricas de Piaget e Kohlberg. As mudanças no comportamento sociais das mulheres incluem uma mudança significativa no comportamento social da maioria das meninas contemporâneas. Por outro lado, embora já seja muito freqüente observar meninas participando de jogos que envolvem disputas diretas, como o 'queimado', o vôlei e mesmo o futebol, o brincar de boneca e de casinha ainda são brincadeiras prevalentes e socialmente valorizadas para a construção da identidade feminina. Poderíamos nos perguntar: haverá o dia em que as brincadeiras infantis não se distinguirão mais por gênero? Parece-nos pouco provável que, mesmo com todos os avanços obtidos com as novas técnicas de reprodução assistida e com todas as possibilidades que possamos imaginar, que a função social feminina em relação à maternidade, ao carregar o filho no ventre por uma gestação, em alimentá-lo em seu próprio seio, comportamentos que acentuam uma característica 'cuidadora' da mulher, as diferenças entre homens e mulheres venham a se extinguir, por mais que as discriminações sociais por gênero sejam reduzidas virtualmente a zero.

Embora o parágrafo anterior possa ser entendido como uma desaprovação à elaboração teórica de Gilligan, esta não era nossa intenção principal, mas sim fortalecer a crítica ao desenvolvimento moral ser entendido como uma mudança de algo, digamos, 'menos bom' para algo melhor, como pretende Kohlberg, onde este 'melhor' seja igual à aceitação de um determinado princípio como valor universal que orientaria toda decisão moral - a justiça. Como assinala Gilligan, as mulheres elaboram o problema moral de forma diferente daquela expressa por aquele autor. Para elas, “o problema moral surge por responsabilidades conflitantes ao invés de conflitos de direitos e requerem para sua solução um modo de pensar que é contextual e narrativo, ao invés de formal e abstrato". Assim, "a moralidade dos direitos difere da moralidade da responsabilidade em sua ênfase na separação e não na conexão, na sua consideração do individual e não no relacionamento, como elemento primário"(Gilligan, 1998:19). Esta sim é sua crítica fundamental: Gilligan acredita que existam caminhos alternativos para o desenvolvimento moral e que estes caminhos derivam de uma ênfase na justiça ou no cuidado. É esta a sua contribuição principal, questionar a teoria do caminho único, da única possibilidade de desenvolvimento moral. 
Como veremos de forma mais amiúde no próximo capítulo, nós defendemos tanto o multiculturalismo ${ }^{60}$ como a compreensão de que a sociedade moderna reflete grande diversidade moral, mesmo entre pessoas que podem ser identificadas como integrantes da mesma sociedade. A diversidade moral, ainda que entre membros da mesma sociedade, lato sensu, é uma realidade inquestionável, e as teorias do desenvolvimento moral não podem ignorá-la. Mas abordaremos estas questões junto com a discussão dos nossos dados empíricos, no próximo capítulo.

\section{Radicalizando em uma Perspectiva Cognitivista}

No nosso entendimento, a questão-chave para a análise do grau de desenvolvimento moral de um sujeito não deve ser a adesão a este ou aquele princípio moral específico. Podemos concordar ou discordar dos valores aceitos pelo indivíduo, e isso não está sendo questionado aqui, mas segundo a própria perspectiva cognitivista, o que precisaria ser considerado seria tão-somente a capacidade individual de analisar racionalmente os problemas morais, independentemente dos valores que ele assume como seus. Estaríamos, portanto, reconhecendo os testes de desenvolvimento moral como instrumentos de análise do desenvolvimento moral segundo um determinado indicador, ou vários deles. 0 teste será tão bom quanto sua possibilidade de detectar os múltiplos aspectos relacionados com o raciocínio moral e como este raciocínio é conduzido.

Em nosso entendimento, a justiça para Kohlberg, e o cuidado para Gilligan são como 'indicadores' que podem ser usados para a análise do desenvolvimento moral de um indivíduo, mas não são necessariamente os únicos, ou necessariamente os melhores, ou muito menos os verdadeiros 'indicadores' de desenvolvimento moral. 0 que determina o desenvolvimento moral de um indivíduo é sua capacidade de raciocinar, autonomamente, e decidir. A autonomia do indivíduo não deve ser tampouco entendida, com esta afirmação, como um

60 Segundo Schramm (2001), "Charles Taylor (Taylor, C. The Politics of recognition. Princeton, UP, 1992), afirma que o multiculturalismo nasce da exigência dos grupos de serem reconhecidos e da necessária tolerância para as democracias pluralistas atuais, as quais devem equacionar os direitos da maioria e o respeito das minorias (caso contrário seriam 'democracias' autoritárias desrespeitosas dos direitos de primeira geração). 0 problema do multiculturalismo se distingue do relativismo pois este afirma, mutatis mutandis, que via de regra todos os comportamentos valem, inclusive a escravatura, etc., sendo portanto em última instância, um niilismo moral, ao passo que o multiculturalismo afirma que, apesar da pluralidade de visões de mundo e do universo dos valores, eu defendo esses, por essas razões, etc.. Essas duas vertentes nascem do fato da descrença sobre o valor do imperativo categórico e sobre o fundamento último da moralidade, mas propõem soluções radicalmente diferentes: a negação da moralidade e a pluralização e complexificação da mesma". 
princípio moral absoluto que deva ou possa ser confundido com um egoísmo ou com a possibilidade de se tomar decisões baseadas nas suas necessidades individuais. A autonomia aqui referida diz respeito ao processo de reflexão único, desenvolvido pelo indivíduo, levando em consideração todos os interesses relacionados com o problema em questão, que pode levá-lo a concluir por uma solução de interesse pessoal ou não, mas tendo sempre como 'pano de fundo' as relações interpessoais que ele empreende(u).

Estamos, assim, estabelecendo como única hierarquia valorativa no desenvolvimento moral o grau de autonomia do indivíduo expresso por sua competência de raciocinar moralmente. Em uma eventual escala, diríamos que 0 indivíduo de menor desenvolvimento moral e, portanto, o que receberia um valor menor, é aquele que não possui a capacidade de considerar os múltiplos aspectos relacionados com a decisão moral, inclusive os emocionais reconhecidamente, não racionais. Um sentimento de solidariedade, reconhecido racionalmente como tal, e que seja decisivo em um processo de tomada de decisão, não representa uma decisão menos autônoma ou que deva ser menos valorizada que outra, baseada apenas em um balanço racional entre os interesses objetivos e subjetivos dos interessados, antes ao contrário - deve sempre ser considerada nos processos de decisão, o que não significa necessariamente submeter a racionalidade à emoção.

Além disso, como já assinalamos, a imagem da escada com degraus para simbolizar a evolução do desenvolvimento moral nos parece de todo inapropriada, sendo mais coerente imaginarmos uma rampa ou talvez, modernamente, a escada-rolante, através da qual a transição entre estágios é muito menos abrupta.

Atribuir no estudo do desenvolvimento moral a análise da adesão do indivíduo a este ou aquele valor significa entrarmos no domínio da ética. $\mathrm{Ou}$, em outras palavras, sair da questão do que é, para a do que deve ser ou que gostaríamos que fosse. 0 raciocínio moral, per se, é um fato desprovido de valor. 0 que implica valor é a ação, pelas conseqüências dos atos para os outros como indivíduos ou coletividade, ao ambiente, ou mesmo ao cosmos. ${ }^{61}$ Associar o desenvolvimento moral, ou seja, a capacidade de raciocinar autonomamente sobre as múltiplas razões, interesses, e conseqüências de um determinado fato, a um determinado princípio ou valor, significa a mesma coisa que avaliar a capacidade de um indivíduo de escrever (estar alfabetizado) pela sua correção

${ }^{61}$ Uma referência aos que, como Edgar Morin, vêm defendendo uma ética planetária. 
gramatical ou pelo conteúdo do que escreve. Nesse sentido, ter competência moral não está relacionado a ser ético. 0 sujeito pode ser moralmente competente e agir coerentemente com sua análise racional, alcançando um resultado diferente daquele que a moralidade vigente percebe como aceitável ou recomendável.

Estamos, assim, efetuando uma distinção entre o campo do raciocínio moral e o campo da prática moral. lsso, obviamente, não nos impede de termos os nossos próprios princípios morais, mas não os estamos colocando em questão. Não é a adesão ao que nós entendemos como um ideal para a sociedade que determinará que alguém possui competência moral ou não. 0 que não impede de termos indicadores desta competência moral, por exemplo, através de testes como os de Kohlberg e Rest. Estes testes avaliam se o indivíduo é capaz de raciocinar moralmente tendo como referência um princípio moral. Assim, para esta moralidade instituída pelo princípio moral da justiça universal, eles podem ser bons testes. Mas estamos então fugindo ao exame da questão específica da capacidade cognitiva de pensar moralmente.

Poderíamos, por exemplo, construir um teste de avaliação de desenvolvimento moral aplicado ao campo da saúde segundo a capacidade do indivíduo de raciocinar tendo como referência o principialismo bioético. Teríamos, então, indivíduos mais ou menos competentes, mais ou menos desenvolvidos moralmente, para lidar autonomamente com os princípios morais desta corrente teórica. Mas, de fato, ele, por esta razão, não deverá ser considerado mais ou menos competente moralmente se, por alguma razão, ele estiver convencido de que a justiça é um princípio moral fundacional.

A nós, e à nossa análise específica da formação moral dos estudantes de medicina, interessa tanto o entendimento de como se processa o desenvolvimento da capacidade de raciocinar moralmente como os valores que são transmitidos através da socialização profissional, seja por meio do currículo formal ou oculto, em experiências intra ou extramuros. A primeira, para que possamos estabelecer ou avaliar estratégias de ensino/aprendizagem; a segunda, para que possamos entender, questionar e, eventualmente, intervir, no já tão referido processo de transformação de jovens idealistas em cínicos, de pessoas preocupadas e motivadas pelo cuidado com o ser humano, em técnicos insensíveis que se preocupam mais com o sucesso e a efetividade da técnica, que pelo paciente no qual ela é aplicada. Pessoas que deveriam ter o cuidado e a responsabilidade pelo outro como valores fundamentais para sua prática e que, muitas vezes, são transformados em seres insensíveis e duros em seus relacionamentos 
com a clientela de humanos e suas situações. É esta a discussão que iniciaremos no próximo capítulo, com a apresentação dos resultados de nossas observações em algumas faculdades de medicina e com entrevistas com estudantes inseridos em todos os momentos do curso.

Uma abordagem bastante interessante e que também avança na perspectiva cognitivista é a apresentada por Kottow \& Schramm (2001), na qual eles propõem que o desenvolvimento moral tal como descrito por Kohlberg seria apropriado para descrever o processo de desenvolvimento até o início da idade adulta, quando então o indivíduo 'estacionaria’ no estágio até então alcançado (em conformidade com a teoria original de Kohlberg). A partir de então, ocorreria um processo de 'enriquecimento de juízo moral', que consistiria em uma ampliação do âmbito moral da pessoa. Tal abordagem teórica encontra sua aplicação mais evidente nas discussões sobre a relação entre o julgamento e a ação morais e busca oferecer um caminho alternativo para a compreensão do juízo moral apenas baseado no princípio da justiça - que os autores denominam como o campo da ética cívica. 


\section{4 \\ 0 Ensino da Ética}

A ciência moderna só se pôde desenvolver em se livrando de qualquer julgamento de valor, obedecendo a uma única ética, a do conhecimento. (Morin, 1996: 10)

Gostariamos de iniciar este capítulo dizendo que no passado, e apenas no passado, era comum os médicos considerarem que, se fossem bons técnicos, seriam necessariamente éticos em sua prática; que ser ético era, para médicos, algo inato. Mas não podemos fazer isso.

Entretanto, este entendimento, presente em muitas das respostas que ouvimos dos estudantes de medicina em nossa pesquisa, reflete um entendimento parcial e limitado da ética e dos aspectos e implicações morais inerentes a este relacionamento tão peculiar, que é a relação médico/paciente. Costuma-se dizer que os problemas e as questões advindos desta relação mudaram de uns trinta ou quarenta anos para cá.

De fato, a incorporação de tecnologias na medicina, fato marcante no século XX, e que pode até ser considerado como uma das razões do sucesso da profissão médica como modelo de organização profissional e corporativa, trouxe ao dia-a-dia da profissão questões que até então eram resolvidas com base na cultura religiosa ou no que podemos chamar de convenções sociais emanadas da corporação médica. Entendia-se e subentendia-se que os médicos dedicavam suas vidas a salvar outras. Que em caso de dúvidas sobre determinada conduta, ou sobre o que fazer, decidiriam pela solução que atendesse aos interesses de seus clientes. Esta característica da profissão, denominada pelos sociólogos de 'ideal de serviço', determinava que um médico, quando confrontado com situações em que seus interesses estivessem potencialmente em conflito com o dos pacientes, optaria pelo encaminhamento que atendesse o paciente. Não que isso não exista mais nos dias de hoje, mas muita coisa mudou - na sociedade, 
na medicina e na maneira de encarar as questões presentes nas relações entre médicos, pacientes, familiares e Estado.

Tomemos, como exemplo, um caso ocorrido em Seattle, Estados Unidos, no início da década de 60 e que, possivelmente, ocorreu também em outras cidades mundo afora. Imaginem como era o tratamento de pacientes com insuficiência renal crônica antes do advento da terapia substitutiva renal. Sem que seja necessário entrar nestes detalhes, podemos dizer que era uma terapia 'heróica', cujo melhor resultado era a minimização do sofrimento do paciente. A uremia era uma sentença de morte. Eis que é desenvolvida uma técnica capaz de substituir parcialmente a função renal, melhorando a qualidade de vida e sua duração, mas é um recurso caro e, especialmente há algumas décadas, com uma oferta muito reduzida. Surge então um dilema para a sociedade e para os médicos em particular: quais serão os pacientes que terão a oportunidade de se submeterem à terapia renal substitutiva? Se até então estava na mente da maioria dos médicos que a vida era sagrada e, portanto, deveria ser salva, neste dilema específico não era possível resolver a questão com este argumento. Não haveria como dizer que vida é mais sagrada que a outra, para assim ter preferência no encaminhamento a esta terapia. Foi preciso que outros princípios morais fossem colocados em discussão, buscando estabelecer uma hierarquia de prioridade fundamentada em alguma racionalidade. Não é interesse nosso apresentar e discutir a solução encontrada pela sociedade de Seattle, mas tãosomente exemplificar o tipo de dilemas e questões que o desenvolvimento e a incorporação de novas técnicas terapêuticas ao quotidiano da prática médica têm proporcionado. Não havia, e não há ainda, consenso, uma solução convencionada pela sociedade para lidar com essas questões.

A prática médica também mudou. Se antes o modelo típico da profissão era a organização e prática liberal, hoje é insensato pensar na medicina sem considerar as grandes corporações que a transformaram em um negócio a mais; e não há espaço mais para romantismo e para imaginar que a medicina mudará, voltando ao tipo de organização que teve no passado. A forma como o mercado de trabalho no setor saúde está organizado é totalmente coerente com o atual estágio do desenvolvimento do capitalismo. A antiga proibição presente nos diversos códigos de ética da profissão, que veda a um médico a exploração do trabalho de outro médico, é apenas mais uma das cegueiras de conveniência que o código de ética médica contém, uma vez que nada é tão comum em nossos dias do que a presença do empresário médico. 
Também os pacientes mudaram. Não são mais apenas aqueles indivíduos desinformados que acatavam a palavra do médico como o anúncio de uma verdade eterna. 0 saber médico científico, efetivamente desenvolvido e consolidado neste século, não é mais de domínio exclusivo desses profissionais. Os meios de comunicação social, sejam eles a televisão, periódicos, coleções de fascículos vendidos em bancas de jornais, ou a Internet, dão acesso fácil a uma gama de conhecimentos que antes só estava disponível nos cursos de formação profissional. É claro que persiste, especialmente em nossa população com baixa escolaridade, muita desinformação. Mas mesmo este segmento da população tem, nos dias de hoje, um acesso maior à informação científica.

Nossa sociedade também mudou - talvez pela primeira vez em nossa história estamos vivendo um período em que os direitos individuais e coletivos conseguem um reconhecimento maior, tanto pela sociedade quanto por seus governos recentes. 0 recente episódio do afastamento de um Presidente da República mediante um processo político e jurídico que concluiu pela declaração de seu impedimento trouxe um novo alento a todos que desejam e trabalham por um país onde o indivíduo seja respeitado em seus direitos. ${ }^{62}$

Nosso país assiste, desde meados da década de 80, a um contínuo crescimento das organizações não-governamentais (ONGs), que se dedicam aos mais diversos temas, entre os quais, a defesa dos direitos humanos e dos interesses de portadores de doenças específicas.

Com a $8^{\text {a }}$ Conferência Nacional de Saúde, iniciou-se um ciclo em que estes grupos sociais organizados passaram a contar com um espaço institucional para discutir a assistência à saúde. Hoje, em todo o país, os Conselhos de Saúde, em seus diferentes níveis, são um espaço concreto de negociação dos interesses dos diversos segmentos envolvidos na assistência. Estas organizações sociais, entretanto, expressam tão-somente, ${ }^{63}$ na maioria das vezes, os interesses específicos de seus integrantes ou dos que sofrem da mesma doença, embora não organizados. Temos, assim, organizações como a dos portadores de doenças

Sem dúvida existe ainda um longo caminho a percorrer, mas não estamos nos propondo a realizar aqui uma análise política ampla. Desejamos tão-somente expressar o nosso reconhecimento de que o caminho democrático é o melhor para a diminuição das injustiças econômicas e sociais, e nossa crença é que neste processo de negociações e de respeito às diferentes posições políticas, nosso país poderá encontrar um caminho que diminua as exclusões sociais.

63 A comparação aqui é entre as organizações que defendem os interesses de portadores de doenças específicas e as associações de moradores e/ou de favelados, sindicatos e outras formas mais tradicionais de organizações de trabalhadores e da população. Não se está fazendo um juízo de valor nesta comparação, apenas assinalando a mudança. 
renais crônicas, ou de portadores de HIV, ou, ainda, de 'ostomizados', que defendem seus interesses na destinação de recursos escassos, sem nenhuma dúvida, buscando, mediante a legítima pressão política, que uma maior parcela deles seja destinada à assistência dos portadores desta ou daquela doença. Representam o que podemos caracterizar como 'interesses tribais'. Ocorre algo semelhante à expressão do individualismo em uma instância coletiva. ${ }^{64}$ Se 0 individualismo é a característica do final do século XX e do início deste, o tribalismo é o fenômeno que o expressa em um nível coletivo.

Enfim, a conclusão óbvia é a de que o mundo mudou. Entretanto, a maioria das escolas de medicina continua a pensar a formação ética de seus alunos com os mesmos instrumentos de ensino e a mesma compreensão do processo que havia no início do século passado. 0 que pretendemos apresentar neste capítulo é uma visão panorâmica de como as escolas médicas lidam com essa questão no Brasil, enriquecida com a análise das observações realizadas em nossa pesquisa; discutirmos como os estudantes entendem a ética aplicada à medicina e como agem nas situações em que acreditam haver uma questão ética em jogo. Ao final, defenderemos a importância do ensino das humanidades médicas e a formulação de estratégias de ensino fundamentadas no atual nível de conhecimento do processo de desenvolvimento moral, conjuminadas ao conhecimento acumulado no campo do ensino da ética.

Antes de iniciarmos esta exposição, gostariamos de apresentar a hipótese que orientava a nossa investigação. Maturana (1998: 72-73) entende a preocupação ética "como preocupação com as conseqüências que nossas ações têm sobre o outro, (...) um fenômeno que tem a ver com a nossa aceitação do outro". Dessa maneira, entende-se que se o outro não está incluído no domínio social de um determinado indivíduo, ele não será objeto de uma preocupação ética. Ou seja, se alguém não inclui, por exemplo, os angolanos que há décadas estão envolvidos em uma guerra sem fim em seu domínio social, pelas razões que sejam, então este sujeito não terá preocupações éticas em relação a este povo. ${ }^{65}$

Pensando no processo de formação profissional em medicina, tal como descrito anteriormente por Becker, com sua ênfase maior nos aspectos técnicos

64 Não tenho conhecimento de pesquisas específicas sobre o tema, mas apenas a observação feita em quatro conferências de saúde, nas quais estivemos diretamente envolvidos.

650 que parece acontecer com a maioria da população mundial, já que muito pouco é feito para se tentar pôr um fim a uma guerra que tantos danos tem provocado à sua população. Mas esta é uma outra questão, envolvendo interesses econômicos, geopolíticos e racismo. 
e físicos, temos mais elementos para compreender este processo, e, simultaneamente, construir nossa hipótese.

Ainda que, em diversas disciplinas do curso médico, seja dada uma ênfase relativa à necessidade de ser estabelecida uma relação médico-paciente, na qual ambos sejam considerados sujeitos do processo, o dia-a-dia da prática nas enfermarias, nos ambulatórios, nas maternidades e emergências são ricos em exemplos de que o paciente é considerado um mero objeto de trabalho, um não-sujeito. Não o reconhecendo como sujeito, não o incluindo em suas preocupações sobre as conseqüências de seus atos, mas apenas como 'o caso do leito 10' ou 'a tuberculose fantástica que internou', será dificil que os estudantes reconheçam como dilemas as questões éticas relacionadas aos seus pacientes quando elas se apresentarem e, uma vez as reconhecendo, será muito difícil tomar uma decisão, já que não estão acostumados e não são estimulados a pensar os problemas em sua dimensão moral.

\section{O Ensino da Ética nas Faculdades de Medicina no Brasil}

Os estudos sobre as relações entre ética e educação/formação profissional ainda são muito incipientes no Brasil. Carecemos de estudos sobre o comportamento e as reflexões éticas dos estudantes de medicina, para então ser possível discutir o próprio processo de desenvolvimento da moral profissional neles. Os estudos disponíveis em nosso país são, em sua maioria, de caráter descritivo sobre a disciplina encarregada de promover o 'ensino'/debate da ética, como veremos a seguir. Para uma melhor compreensão de como esta é ministrada nas faculdades médicas do país, apresentaremos, a seguir, um breve panorama dos principais trabalhos já publicados sobre esta temática.

Foram identificados alguns trabalhos (Coura, 1984; Meira \& Cunha, 1994) que se reportam ao reconhecimento das disciplinas nas quais 0 conteúdo da temática ética é lecionado, à quantificação dos docentes e respectivas formações básicas, carga horária dedicada ao tema etc. Sistematizaremos apenas o trabalho mais recente, com o intuito de apresentar um panorama da situação do ensino da ética nas escolas médicas no início da década de 90 do século passado (Meira \& Cunha, 1994). Sendo um estudo realizado em 1992, suas informações já não traduzem a provável situação 
atual, ${ }^{66}$ uma vez que foi exatamente neste periodo que a maior discussão sobre o campo da bioética ocorreu em nosso país, tendo sido, inclusive, criada a Sociedade Brasileira de Bioética (SBB).

Sabemos, por exemplo, que diversas escolas médicas vêm criando disciplinas de Bioética, muitas vezes sem substituir a disciplina de Ética já existente, mas isso não representa, necessariamente, uma mudança significativa. Tal estudo, apesar de suas limitações ao restringir seu inquérito aos coordenadores de curso e ao satisfazer-se com perguntas genéricas, tem sua validade por demonstrar aquela que tem sido a característica fundamental na abordagem da ética na escola médica - limitar-se ao estudo da deontologia.

$\mathrm{Na}$ época em que o estudo foi realizado, havia 79 escolas em funcionamento no país. Destas, 4 informaram que não dispunham de uma disciplina específica para o ensino da ética, sendo uma por ser de criação recente e não dispor de alunos na série em que tal disciplina estava prevista para ser ministrada e a outra por informar que "o ensino estava diluído na ministração de todas as disciplinas do currículo" (Meira \& Cunha, 1994: 7).

Das 75 escolas que já dispunham de uma disciplina para o ensino de ética, em apenas 25 delas esta era uma disciplina 'autônoma' - sem outros conteúdos que não a ética. Das restantes, em $94 \%$ das escolas a disciplina tinha a palavra deontologia em seu nome. Merecem referência, não pelo número de escolas que adotaram esta nomenclatura, mas pelo inusitado das associações temáticas: 'Deontologia e Patologia' e 'Medicina Legal, Psicopatologia Forense e Ética Médica'.

Refletindo um caráter marginal no curso médico, em 31 faculdades, apenas um docente ministrava todas as aulas sobre o tema. Em 33 delas eram dois professores. Entre os coordenadores da disciplina prevaleceram, como já era de se esperar por seu próprio nome, os de formação médica $(95,1 \%)$. Destes, $6,5 \%$ também eram graduados em direito. Os três restantes eram formados em direito $(1,3 \%)$, filosofia $(1,3 \%)$ e psicologia $(1,3 \%)$.

As aulas eram realizadas nos mais variados momentos do curso, sendo a maior freqüência verificada na $4^{\mathrm{a}}$ série $\left(40,5 \%\right.$ das faculdades) e na $5^{\mathrm{a}}$ série $(32,9 \%)$. Embora nas demais faculdades a disciplina fosse dada nas demais séries, esta concentração parece corroborar a idéia de que, sendo de conteúdo

No recente Congresso Brasileiro de Medicina Legal em Recife, o Prof. Daniel Munhoz apresentou alguns dados de uma pesquisa recém-finalizada com um novo panorama do ensino da ética nas faculdades de medicina e de direito. 0 trabalho, entretanto, ainda não está publicado. Os dados apresentados não diferem muito dos que são aqui apresentados. 
fundamentalmente deontológico, sua inserção no currículo naquelas séries é coerente, uma vez que trataria apenas de apresentar as normas e regras a serem seguidas no exercício profissional, sem uma preocupação de estimular o desenvolvimento da capacidade dos estudantes de analisar e tomar decisões sobre questões que envolvam aspectos morais.

Apenas 3,5\% das escolas ministravam suas aulas teóricas para pequenos grupos de alunos, menos de 20 alunos. Entre as que afirmaram oferecer aulas práticas, 27 escolas, apenas cinco o faziam em pequenos grupos. Meira \& Cunha, entretanto, não apresentaram informações sobre as características dessas aulas, o que nos priva da possibilidade de uma melhor e efetiva compreensão de como se dava o processo de ensino da disciplina.

Finalmente, os autores nos ofereceram uma relação dos dez temas mais referidos pelos coordenadores de disciplinas ao serem instados a relacioná-los segundo a importância atribuída no curso. 0 Quadro 3 (Meira \& Cunha, 1994) não apenas confirma o conteúdo deontológico do ensino, como possibilita a comparação com o ensino observado em outros países.

Quadro 3 - Distribuição dos temas mais importantes para o ensino da ética médica por indicação dos responsáveis pela matéria em faculdades médicas do Brasil - Brasil, 1992

\begin{tabular}{|lc|}
\hline \multicolumn{1}{|c|}{ Temas } & № de indicações \\
\hline Responsabilidade profissional do médico & 55 \\
Segredo profissional & 48 \\
Relação médico-cliente & 38 \\
Código de ética médica vigente & 32 \\
Ética do início da vida & 29 \\
Ética do fim da vida & 25 \\
Erro médico & 21 \\
Ética dos transplantes & 20 \\
Remuneração profissional do médico & 20 \\
Exercício lícito e ilícito da medicina & 18 \\
\hline
\end{tabular}

Fonte: Meira \& Cunha (1994). 
Este temário pode ser utilizado para, 'grosso modo', conformar o campo tradicionalmente abordado nas faculdades de medicina sob o nome de ética ou deontologia. Podemos notar que toda a abordagem está voltada para o futuro exercício profissional, ou seja, para quando o aluno estiver graduado. Não há, entre estes, nenhuma referência aos conflitos e dilemas éticos com os quais eles se defrontam ainda como estudantes.

Vejamos com o trabalho de Kopelman os conteúdos disciplinares que conformam o campo entre as escolas médicas americanas. No levantamento desta autora, foram incluídas as disciplinas de ética médica, bioética e filosofia da medicina.

- Objetivos da Medicina, códigos, juramentos e convenções;

- A relação médico-paciente;

- Honestidade, veracidade e confiabilidade;

- Consentimento esclarecido para o tratamento e a pesquisa;

- Ação voluntária e capacidade de autodeterminação;

- Vida vegetativa, diminuição de capacidade e qualidade de vida;

- Questões reprodutivas e conflitos materno-fetais, incluindo aborto;

- Conceitos de saúde, doença, enfermidade e inabilidade (incapacidade);

- Desenho de pesquisa, ensaios clínicos, a relação investigador-objeto e as recomendações atuais para a pesquisa;

- Confidencialidade e privacidade;

- Tomada de decisões para pacientes incompetentes ou incapacitados;

- Morte e morrer: critérios, definições e significados da morte; manutenção de tratamento; diretivas avançadas, suicídio assistido por médico e eutanásia;

- Genética e screening genético e novas tecnologias;

- Modelos de explanação, justificação e tomada de decisões;

- Alocação de recursos, managed care, acesso e ‘saída' do sistema de saúde.

(Kopelman, 1995: 796)

Esta autora não considera relevante nem imprescindível a discussão sobre este campo do saber. Antes, o importante é considerar como incorporar os objetivos e habilidades fundamentais a toda reflexão filosófica na medicina. Os objetivos e habilidades são:

- identificar e examinar suposições;

- ampliar as perspectivas do aluno e aumentar o autoconhecimento;

- desenvolver habilidades críticas de pensamento;

- nutrir a tolerância, abertura e o ceticismo sobre dogmas;

- cultivar a empatia. (Kopelman 1995: 797) 
Amargo (1996: sem página), analisando os dados da pesquisa de Meira \& Cunha (1994), destaca que "a deontologia não atende a um dos objetivos primordiais da educação, qual seja, o desenvolvimento de comportamento moral nos alunos dos cursos médicos. (...) 0 comportamento moral é movido por valores interiores à pessoa, não pelo conhecimento da norma e/ou o medo à punição".

Coura (1984: 2), por sua vez, embora faça um adequado questionamento sobre os conteúdos estritamente deontológicos dessas disciplinas, preconiza que "o ensino da Ética médica deveria ser feito de forma doutrinária e exemplar por professores-médicos entre os mais experientes”. Reitera-se, assim, uma concepção de que o ensino da ética deve ser de forma a doutrinar o estudante, sem que a este seja conferida a possibilidade de refletir sobre as questões e acostumar-se a desconfiar dos dogmas e/ou das normas absolutas.

Hossne (1998) foi pioneiro no Brasil na abordagem do tema 'Ética e Educação Médica' que, além da tradicional, e ao mesmo tempo ineficaz, crítica aos conteúdos deontológicos, abordou a questão das situações às quais os estudantes estão submetidos e que incluem uma implicação ética. Referiu-se, explicitamente, às

pequenas mentiras, comentários inadequados, condutas médicas inadequadas, 'paternalismos', tráfico de influência, maneiras inadequadas (e até desrespeitosas) no trato com os pacientes ou com a equipe de saúde, ruptura de sigilo, manuseio inadequado dos prontuários, 'furto' de uma radiografia demonstrativa, perda do prontuário ou de exames, falta de atenção ou tratamento autoritário com a família e atestado falso. (Hossne, 1998: 136)

Ainda que as disciplinas 'preferenciais' para o ensino da ética sejam as de medicina legal, deontologia médica e afins, nosso estudo detectou outras disciplinas em que foram introduzidas discussões sobre a ética ao longo do curso. Perguntamos a 74 alunos, originários de 22 escolas médicas diferentes, distribuídas por 13 estados da federação (ver no Quadro 4 a relação de faculdades e estados dos estudantes entrevistados durante o XXX Encontro Científico dos Estudantes de Medicina em São Luís, Maranhão), se eles já haviam tido alguma aula de ética na faculdade e, em caso positivo, em que disciplina e em que período. ${ }^{67}$

\footnotetext{
67 A população estudada não constitui uma amostra dos alunos das escolas médicas no Brasil e nem dos estudantes presentes no Encontro Científico dos Estudantes de Medicina. As informações são válidas unicamente para os alunos entrevistados, sendo trabalhadas como em um estudo exploratório.
} 
Quadro 4 - Faculdades onde estudavam os estudantes incluídos no inquérito sobre ética na formação - Brasil, 2000

\begin{tabular}{|c|c|}
\hline Faculdade & Estado \\
\hline Escola de Ciências Médicas de Alagoas & AL \\
\hline Universidade Federal do Ceará & CE \\
\hline Universidade Federal do Maranhão & MA \\
\hline Universidade Federal de Minas Gerais & MG \\
\hline Universidade Federal de Uberlândia & MG \\
\hline Universidade Federal do Mato Grosso do Sul & MS \\
\hline Universidade Federal do Pará & PA \\
\hline Universidade Federal da Paraíba & PB \\
\hline Universidade Federal de Pernambuco & PE \\
\hline Universidade Estadual de Pernambuco & PE \\
\hline Universidade Federal do Paraná & PR \\
\hline Faculdade de Medicina de Petrópolis & RJ \\
\hline Universidade Estadual do Rio de Janeiro & RJ \\
\hline Universidade Federal do Rio de Janeiro & RJ \\
\hline Universidade Gama Filho & RJ \\
\hline Universidade Severino Sombra & RJ \\
\hline Universidade de Nova lguaçu & RJ \\
\hline Universidade Federal do Rio Grande do Norte & RN \\
\hline Pontifícia Universidade Católica de Porto Alegre & RS \\
\hline Universidade Mogi das Cruzes & SP \\
\hline Universidade Federal de São Paulo & SP \\
\hline Universidade de Taubaté & SP \\
\hline Total & 22 \\
\hline
\end{tabular}

Fonte: quadro elaborado pelo autor. 
0 Quadro 5 apresenta a relação das disciplinas nas quais foram ministradas aulas sobre ética, nas faculdades dos estudantes entrevistados. A diversidade encontrada é semelhante àquela apontada pelo já citado trabalho de Meira \& Cunha (1994), embora devamos salientar que, aqui, não estamos identificando as disciplinas responsáveis pelo ensino da ética, mas aquelas em que algum conteúdo sobre ética é ministrado. Considerando que a maioria dos alunos entrevistados por nós estava no ciclo básico (40), e 33 no ciclo profissional, mas que foram 47 os que afirmaram terem tido alguma aula de ética em disciplinas do ciclo básico, e que Meira \& Cunha (1994) fizeram referência a mais de 70\% das disciplinas de ética presentes no ciclo profissional, entendemos as informações por nós obtidas como sugestivas ${ }^{68}$ de que as escolas possam estar se preocupando mais em inserir conteúdos sobre ética em outras disciplinas, além das tradicionais, e de forma mais precoce. Quadro 5 - Relação das disciplinas em que foram ministradas aulas sobre ética referidas pelos estudantes incluídos no inquérito sobre ética na formação - Brasil, 2000

\begin{tabular}{|c|c|c|}
\hline Nome da disciplina & Ciclo & Períodos citados \\
\hline Ações Integradas de Saúde & Básico & $3^{0}$ \\
\hline Aula inaugural & Básico & $1^{\underline{0}}$ \\
\hline Bioética & Básico/Profissional & $1^{\circ}, 2^{\circ}, 5^{\circ}, 6^{\circ}, 11^{\circ}$ \\
\hline Deontologia médica & Básico/Profissional & $1^{\circ}, 2^{\underline{0}}, 3^{\circ}, 5^{\circ}$ \\
\hline Embriologia 1 & Básico & $1 \underline{0}$ \\
\hline Ética aplicada à saúde & Básico & $2^{\underline{0}}$ \\
\hline Ética da saúde & Básico & $2^{\underline{0}}$ \\
\hline Ética Médica & Básico/Profissional & $1^{\circ}, 2^{\circ}, 3^{\circ}, 4^{\circ}, 7^{\circ}$ \\
\hline $\begin{array}{l}\text { Fundamentos Científicos e } \\
\text { éticos da pesquisa médica }\end{array}$ & Básico & $1^{0}$ \\
\hline Medicina Legal & Profissional & $8^{\underline{0}}$ \\
\hline Psicologia & Profissional & $5^{0}$ \\
\hline Psiquiatria social & Básico & $1^{\underline{0}}$ \\
\hline Saúde Pública & Básico & $1 \underline{0}$ \\
\hline Tocoginecologia & Profissional & $6^{0}$ \\
\hline
\end{tabular}

Fonte: quadro elaborado pelo autor.

68 Como o conjunto de alunos entrevistados não constitui uma amostra, não é possível afirmar peremptoriamente a mudança, embora o fenômeno observado seja válido como indicador da experiência dos alunos entrevistados. 
O Ministério da Educação do Brasil tem produzido, em conjunto com especialistas nas respectivas áreas, uma série de documentos que buscam atender às exigências da nova Lei de Diretrizes e Bases da Educação, estabelecendo os parâmetros curriculares nacionais, para o Ensino Fundamental, e as diretrizes curriculares mínimas, para o Ensino Profissional. Ainda que os parâmetros curriculares nacionais tenham como objeto o ensino de primeiro grau, suas recomendações já são discutidas como uma orientação também para o ensino de graduação, especialmente nos casos em que aponta para a necessidade de se implementar o ensino transversal de temas específicos: Ética, Meio Ambiente, Pluralidade Cultural, Saúde e Orientação Sexual (Brasil, 1997). Hoje, o debate sobre a inclusão da ética como um tema transversal no ensino da graduação começa a ser estabelecido em fóruns acadêmicos relacionados ao ensino da medicina.

Com o objetivo de conhecer melhor como o ensino da ética é considerado em nossas escolas, bem como com que meios os estudantes contam para desenvolver sua capacidade de pensar aspectos morais diretamente relacionados com o 'tornar-se médico', escolhemos uma faculdade de medicina para uma análise sistemática sobre seu processo de ensino. Esta faculdade, de natureza pública, dispõe de infra-estrutura e corpo docente comparável às melhores faculdades do país. Realizamos uma análise das ementas das disciplinas obrigatórias e eletivas presentes em seu 'Catálogo do curso médico' ${ }^{69} \mathrm{e}$, por sugestão de alunos vinculados ao Centro Acadêmico, ${ }^{70}$ a observação de algumas aulas teórico-práticas de propedêutica médica e de semiologia médica.

A análise do catálogo de curso não pode desconsiderar o reconhecido distanciamento entre pensamento e ação, teoria e prática. Nenhum currículo ou grade curricular expressa a realidade de um curso, servindo tão-somente como objeto de análise das intenções educacionais, no caso, da faculdade em questão.

Assim, não podemos incorrer no erro de considerar a grade curricular como uma expressão da realidade do curso, mas, quando muito, uma manifestação de intenções e uma expressão ideológica de seus formuladores. Feita a ressalva devida, observamos que na faculdade analisada a disciplina responsável

\footnotetext{
Em atenção ao disposto na Resolução 196/96 do Conselho Nacional de Saúde, esta universidade não será identificada. Inquiridos sobre quais os momentos em que aspectos relacionados à relação médico-paciente eram abordados de forma mais significativa na opinião deles, os estudantes afirmaram que estas duas disciplinas eram estratégicas, por serem as primeiras oportunidades em que os estudantes se relaciona de forma mais amiúde com pacientes, através da realização da anamnese e do exame físico. As observações realizadas nas aulas práticas, quando se referirem às situações envolvendo aspectos éticos, serão apresentadas em conjunto com os resultados do inquérito com os estudantes de outras faculdades do país, realizado no XXX Ecem, no Maranhão, no ano de 2000.
} 
pelo ensino de ética médica é a de 'medicina legal', ministrada no 9o período do curso pelo Departamento de Psiquiatria e Medicina Legal. A ementa da disciplina a descreve como "o estudo das relações da Medicina com o Direito nos campos penal, civil, administrativo e ético”. Entre os conteúdos descritos, estão presentes a deontologia e a diceologia médica. A metodologia do curso prevê "aulas teóricas e práticas de necropsia forense em casos de morte violenta". $\mathrm{Na}$ bibliografia, apenas o Código de Ética Médica sugere ser esta a disciplina encarregada do ensino da ética.

A situação, entretanto, é melhor do que a leitura desta simples ementa sugere. Logo no $3^{\circ}$ período do curso, na disciplina ações integrais de saúde, de caráter transdepartamental, um dos módulos ministrados é o de 'Introdução à Bioética'. A ementa dessa disciplina prevê: “ 0 conceito e a prática da saúde integral do indivíduo: dimensões biológica, psicológica, social e ética. Introdução à Bioética. A relação médico-paciente”. Já o programa do módulo de bioética prevê: "Introdução à Bioética: conceitos e fundamentos da ética e da bioética. Bioética clínica: segredo profissional médico; remuneração profissional; responsabilidade profissional; pesquisa biomédica. Aspectos legais do exercício profissional. Bioética social”. Apesar de o programa do módulo não ter efetivamente maiores relações com a bioética, sugerindo que a adoção desse nome tenha sido mais em função de conferir um 'toque de modernidade' ao módulo, seu conteúdo expressa o que esperávamos encontrar na disciplina responsável pelos conteúdos de ética médica, no caso, a de medicina legal. Esses conteúdos, embora reconhecidamente insuficientes para preparar o estudante de medicina para lidar com os aspectos morais relacionados com a prática de sua futura profissão, são conteúdos que entendemos como fundamentais na formação do médico, por expressarem a moral profissional na qual o aluno está sendo socializado.

Mas é alvissareiro que sejam encontradas, nas ementas de outras disciplinas, a preocupação com as 'implicações éticas' da prática médica relacionada na prática daquelas especialidades. São elas: ginecologia, ortopedia e traumatologia, obstetrícia e o internato em clínica médica e cirurgia. Este fato tanto pode significar uma efetiva preocupação com a necessidade de se discutir a ética na formação, como também representar tão-somente iniciativas isoladas de alguns coordenadores de disciplinas ou de mestrado, sem que isso reflita um consenso daquela unidade da universidade. Outros poderiam também dizer que esta inserção na ementa não tem maior significado, que não a velha concepção segundo a qual ensinando-se a boa técnica estar-se-á ensinando um comportamento ético. 
0 início das discussões sobre a bioética no Brasil, que poderíamos imprecisamente situar no período de redemocratização do país, trouxe um elemento a mais para os debates sobre a relação médico-paciente, até então restritos ao psiquismo e ao cumprimento das determinações que figuravam no Código de Ética Médica; trouxe, igualmente, uma complicação política a mais, para a sua introdução como disciplina nas faculdades brasileiras - a perspectiva de alguma mudança no currículo. A complicação política é facilmente compreendida: sendo a universidade conservadora por característica (Santos, 1995) e também resistente às mudanças curriculares ${ }^{71}$ (Merton, 1957), a perspectiva de um novo tema a ser introduzido gerou discussões de três tipos, embora de naturezas diferentes:

- Deverá a bioética ser considerada uma nova disciplina mesmo?

- Deverá a bioética substituir a disciplina de ética médica?

- Que departamento deveria ser o responsável pela nova disciplina?

Aqueles familiarizados com as disputas de poder no interior de estruturas acadêmicas sabem que a conformação dos currículos expressa não apenas a compreensão docente dos problemas e da estratégia de ensino mais relevante para a formação do estudante, como também, e a importância não pode ser subestimada, a distribuição de poder dos diferentes departamentos das faculdades.

Como uma federação departamental em tempos de recursos escassos, as escolas de medicina vivem uma situação de disputa permanente por prestígio e os recursos dele resultantes. Se em um passado não muito distante os departamentos das especialidades básicas eram quase consensualmente considerados como os mais importantes dentro da logística do processo de formação, nos dias de hoje, aqueles que estejam envolvidos com pesquisas que proporcionam maiores captações de recursos asseguram posições de destaque e de poder não compatíveis com sua contribuição no currículo e no processo de formação.

Departamentos com pequena possibilidade de competir por recursos apegam-se à competição pelo que poderíamos chamar de sinais indiretos de prestígio e de poder - a quantidade de tempo que ocupa na grade curricular e os temas que aparentemente possam lhes conferir uma aura de modernidade.

Assim, a lógica da discussão sobre a bioética deixa de ser técnica e passa a ser político-administrativa - passa a ser tão-somente uma disputa por poder

“ 0 processo de competição por tempo que ocorre na construção da estrutura curricular, bem como os conflitos intensos que ocorrem entre as pessoas de departamentos diferentes, (...) leva, em geral, a um equilibrio de forças entre os departamentos, e o resultado é que tudo permanece como estava antes" (Merton, 1957: 24). 
entre departamentos pouco significativos na estrutura da faculdade, seja por sua condição não central no processo de formação, seja por sua incapacidade de captar recursos expressivos para a faculdade com seus projetos, que possui, entre outras características, a de se utilizar tradicionalmente de tecnologias mais simples - os departamentos de Medicina Preventiva e de Medicina Legal e, eventualmente, o de Psicologia Médica, quando existente.

Abriremos um breve parêntesis para algumas considerações sobre a bioética no Brasil. Em nosso país, e possivelmente em muitos países da América Latina, docentes e pesquisadores da área da saúde pública, talvez por terem como objeto de trabalho as grandes populações e preocupações típicas com os valores de justiça sanitária, parecem ter encontrado na bioética o campo da ética em que, por excelência, podem expressar suas preocupações morais e ideológicas com a coletividade.

A bioética oferece um referencial teórico filosófico que é muito útil para justificar suas concepções ideológicas, em sua luta política por justiça e eqüidade. Enquanto o caminho do desenvolvimento desta disciplina, particularmente nos Estados Unidos, ocorreu em meio a um intenso debate sobre o movimento de afirmação e confrontação dos direitos individuais com as ações e princípios de governo e/ou de cunho religioso, no Brasil e na América Latina, ela é introduzida mais tardiamente.

Apesar de entendermos que uma análise sociológica sobre o surgimento da bioética em nosso país mereceria um estudo específico, capaz de reconstruir seus diversos momentos, não é possível deixar de reconhecer que o processo de democratização da sociedade brasileira, com a reconquista formal dos direitos políticos e civis na década de 80 , foi um fato indispensável. Da mesma maneira, não é possível ignorar que as mudanças políticas que se seguiram à $8^{a}$ Conferência Nacional de Saúde, com o incentivo à participação e à organização popular na discussão sobre a política de saúde, foram também decisivas para que se intensificasse 0 questionamento sobre as conseqüências das ações na área da saúde.

Parece-nos claro que por ter ocorrido em conjuminância ao amplo movimento político chamado Reforma Sanitária e por atender aos interesses da comunidade religiosa católica, que tradicionalmente tende a restringir seu foco às questões com regras gerais de comportamento, evitando discutir cada caso como um caso em particular, grande parte dos que se dedicam ao estudo da bioética no Brasil atualmente tende a eleger a justiça como o princípio maior, quase absoluto, para esta disciplina, tendendo a minimizar a importância e a 
pertinência da discussão de um enfoque que não admita princípios absolutos, mas que considere fundamental a discussão de cada caso particularmente, evitando a definição de soluções prévias.

Em nome da dívida social e da eqüidade, restringe-se mais uma vez a discussão dos direitos individuais. Fechando nosso parêntesis, mas restabelecendo o vínculo com nossa discussão básica, diríamos que estas disputas, tais e quais vêm ocorrendo, em nada contribuem para a formação de novos médicos que sejam capazes de reconhecer, na pluralidade e na diversidade de convicções morais, elementos indispensáveis para o desenvolvimento de seu caráter e para ajudá-los a atuar profissionalmente em uma sociedade indiscutivelmente pluralista e democrática.

Começando a responder agora àquelas nossas perguntas sobre a bioética, ${ }^{72}$ diríamos que sim, ela é uma disciplina, assim como existe um profissional especializado em bioética. Schramm contradiz a concepção de que a bioética é um campo interdisciplinar ao afirmar que:

a interdisciplinaridade não elimina a especialização em algum aspecto do campo, caso contrário, não teríamos mais nenhuma especialidade, o que é totalmente contra-intuitivo. (...) existe um rigor metodológico na maneira de analisar os problemas que fazem com que o bioeticista, que possui formação filosófica, seja um profissional da análise moral. (Schramm, 2000: 11)

Entretanto, embora seja uma disciplina, isso não quer dizer que para discutir bioética seja necessário que o indivíduo seja um especialista, o que seria, por sua vez, um contra-senso. Discutir os aspectos morais da prática em saúde é uma necessidade para todos os profissionais que nela atuam. 0 que se assinala é que o profissional especializado em bioética está mais preparado, do ponto de vista cognitivo, para promover o debate, devido à sua formação filosófica. Como afirma Schramm (2000: 11), "não é tanto dizer (que) tem que ser assim ou assado, é tentar fazer com que as questões e os argumentos surjam”.

Uma frase repetidas vezes citadas pelos estudantes em nossa pesquisa era a de que 'ser ético é ter bom senso'. Este bom senso, que pode ser entendido como a moral convencional ${ }^{73}$ ou como uma "moral espontâ-

As perguntas eram: deverá a bioética ser considerada uma nova disciplina mesmo? Deverá a bioética substituir a disciplina de ética médica? Que departamento deveria ser o responsável pela nova disciplina?

73 No sentido dado por Turiel a 'convenção' como não pertencendo ao domínio da moral, teremos de admitir que falar de moral convencional é um contra-senso, embora seja útil para delimitar um sentido para o 'senso comum' ou 'bom senso'. 
nea', ${ }^{74}$ precisa ser contraposto a uma 'moral crítica', entendida por Schramm (2000: 10) como aquela que "permite ir contra nossas intuições morais, exatamente através da argumentação racional e imparcial, que surge do encontro com o outro ou devido a novas situações”.

Embora, inegavelmente, seja bastante razoável e necessário que as pessoas tenham a percepção da moral 'majoritariamente' aceita pela sociedade em que vivem, sua simples identificação não permite que o indivíduo consiga lidar satisfatoriamente com a pluralidade moral, salvo se o respeito pela diversidade fosse um dos valores fundacionais desta sociedade -, o que decididamente não é o caso da sociedade brasileira nem quiçá da humanidade. ${ }^{75}$

Contudo, este senso comum ao qual os estudantes se referem, pode estar representando a percepção que a maioria dos médicos tem da ética profissional, que representaria uma 're-interpretação' dos princípios tradicionais da medicina em um clima 'hobbesiano' ditado pelo acirramento da competição no capitalismo, pela globalização e, como dizia Christopher Lasch (1986) em seu livro O Mínimo Eu: sobrevivência psíquica em tempos de crise, de problemas cujas soluções não parecem estar no domínio do indivíduo. Mas isso seria uma hipótese para um outro estudo, não uma explicação para o que nós observamos neste livro.

\section{Aprendendo Semiologia no Colega}

Da observação que fizemos nas aulas de semiologia, gostariamos de destacar, neste momento, uma característica do modelo utilizado: antes de examinar doentes 'reais', os estudantes treinam o exame físico em seus próprios colegas. Neste modelo, na faculdade em questão, as turmas são divididas em pequenos grupos escolhidos pelos próprios alunos, existindo a possibilidade de os grupos e professores serem os mesmos desde a disciplina de propedêutica.

74 Esta, conforme Schramm (2000: 12), deve ser entendida como a moral "que todos nós temos, que aprendemos dos pais, da escola, do viver em sociedade, que é uma moral intuitiva, via de regra suficiente para viver o dia a dia a partir do nosso olhar".

75 Poderiamos argumentar que, após a Revolução Francesa, em 1789, marco simbólico do início da ldade Contemporânea, as sociedades ocidentais passaram também a ter seu lema "lgualdade, Fraternidade e Liberdade" como valores fundamentais para sua organização. Mas pensamos que os ideais da Revolução Francesa são muito recentes para serem capazes de alterar séculos de senso comum de exclusão e de dominação, inclusive, a despeito das também recentes reinterpretações que as religiões ocidentais realizaram no século XX de seus livros sagrados, com profundo substrato religioso. Somente através do esforço racional, do desenvolvimento da consciência crítica dos indivíduos, por muitos e muitos anos, será possível que o senso comum da ética seja fundamentado na tolerância e no respeito aos desiguais. 
Existe um programa na disciplina a ser seguido e cumprido; o professor possui liberdade para programar suas aulas dentro das diretrizes do programa adotado, mas a flexibilidade é relativa. 0 programa precisa ser cumprido e os estudantes comparam o ritmo de seu grupo com o dos outros. Nas aulas a que assistimos, o grupo era de oito alunos e o professor utilizou um consultório desativado, mas com equipamentos básicos, como local das aulas.

Todos os alunos demonstravam ter estudado previamente o conteúdo da aula de forma que esta foi muito dinâmica, com intensa participação dos alunos. A aula prática se dá inicialmente com o exame de um dos alunos, que se apresenta como 'voluntário' para ser examinado. De fato, na aula em que esse recurso foi utilizado, a turma docemente constrangeu um dos colegas a ser o voluntário. Ficou subentendido que outros já haviam sido e que aquela era a hora dele. 0 aluno não demonstrou constrangimento com a 'determinação' de que aquela seria a sua hora e nem durante as atividades práticas. Depreende-se que aquela situação, no caso do grupo específico envolvido, era bem resolvida entre as partes, embora tenham ocorrido brincadeiras e gozações sobre 0 voluntariado. 0 professor não influiu na escolha, tendo apenas determinado que não fosse a única mulher do grupo. A aula em questão era sobre exame físico do abdome - inspeção, palpação (superficial e profunda) e percussão. Soubemos que as atividades práticas nos próprios colegas limitam-se a determinados exames, não incluindo órgãos sexuais.

Conversando com alunos de outros grupos, soubemos que esta é realmente uma prática habitual naquela faculdade, constituindo-se em um modelo de ensino. Não é muito comum em nosso país o registro formal da introdução de práticas novas de ensino, razão pela qual é muito difícil identificarmos as razões e mesmo o período em que este tipo de atividade foi iniciada na faculdade observada. Em países como Estados Unidos e Canadá, onde ela iniciou-se, é uma prática bastante difundida atualmente e utilizada em cursos introdutórios de clínica com o objetivo de familiarizar os estudantes com as técnicas de exame antes que encontrem pacientes nas clínicas (Chang \& Power, 2000).

Lá, como aqui, não se realizam exames no que chama de 'áreas sensiveis' (mamas femininas, órgãos pélvicos, genitálias externas, reto, canal anal e ânus e região inguinal), embora seja tolerada a realização de exames para identificação do ictus cardíaco e palpação de artéria femural, o que torna contraditório o elenco de áreas restritas assinaladas. Chang e Power realizaram um surveyentre alunos de cursos pré-clínicos em uma faculdade americana, buscando identificar 
eventuais constrangimentos dos alunos. A maioria (97\%) informou que não sente constrangimentos em ser examinado por um colega, embora, na análise de áreas específicas, o constrangimento aumente quando o exame é entre colegas de sexo diferente.

Uma das estratégias utilizadas pelas faculdades americanas e canadenses para evitar constrangimentos entre colegas e o contato dos jovens e destreinados estudantes com pacientes é a contratação de modelos profissionais, nos quais são realizados os exames 'nas áreas sensíveis'. 0 que o artigo de Chang e Power não questiona, e que precisa ser pensado também, são as implicações éticas relacionadas com esta prática e que gostaríamos de assinalar: e se o aluno se recusar a ser modelo, como será assegurada sua autonomia para esta decisão? Existem mecanismos para que ele possa realmente tomar uma decisão livre de constrangimentos? E se, por um acaso, não totalmente improvável, o exame detectar alguma anormalidade, como ficaria o direito à privacidade?

Entendemos que a questão fundamental a ser assegurada nos ambientes de ensino onde será solicitado aos estudantes que sejam objeto do exame de seus colegas é o direito de, sem constrangimentos, o estudante se recusar. É razoável que seja preservada a utilização de procedimentos semelhantes aos que são preconizados para a participação de um indivíduo em uma pesquisa, nos termos da normatização brasileira de ética em pesquisa. 



\section{5 \\ Os Estudantes de Medicina e seus Valores}

Quem são os estudantes de medicina que estão sendo graduados atualmente? A melhor resposta para essa pergunta, no que se refere às características socioeconômicas, encontra-se nos resultados do inquérito, preparado pelo Instituto Nacional de Estudos Pedagógicos (Inep), implementado para os estudantes graduados no ano de 2000, e que foi aplicado durante a realização do Exame Nacional de Avaliação dos Cursos de Medicina (Provão).

Os resultados desse questionário estão disponíveis on line, na Internet (Brasil, 2000). Em um breve resumo, podemos dizer que os dados confirmam, de uma maneira geral, aquilo que se não era sabido para este segmento específico, era intuído pela maioria das pessoas: os estudantes de medicina são, em geral, filhos da classe média, que estudaram, em sua maioria, em colégios particulares, moram com seus pais e são solteiros. Ou seja, a maior parte desses estudantes não tiveram de trabalhar para pagar a faculdade e ingressaram com um capital cultural muito acima da média da população brasileira.

Entretanto, quando observamos as respostas fornecidas sobre 'hábitos de leitura', o que poderíamos classificar aproximadamente como 'cultura geral', os resultados são desapontadores, pois demonstram que a formação médica é incapaz de abrir horizontes diferentes daqueles do universo médico.

Mais da metade dos estudantes graduados no ano passado afirmaram que lêem jornais com uma freqüência igual ou menor do que "somente aos domingos'. Apenas cerca de 20\% deste universo afirmou ler jornais diariamente. Se compararmos estes resultados àqueles referentes aos estudantes que se graduaram em direito no mesmo ano, verificaremos que o índice obtido pelos estudantes de medicina é menor que a metade de seus colegas do curso de direito.

Ao serem perguntados pelo número de livros que leram em média durante cada ano do curso, excetuando-se os relacionados ao curso, cerca de 12\% 
dos novos médicos afirmaram não terem lido nenhum; cerca de 25\% afirmaram terem lido um e em torno de $40 \%$ teriam lido dois ou três. Esses resultados também são significativamente inferiores aos verificados entre os alunos graduados em direito.

Consideramos que, ao restringir seu universo de experiências e informações basicamente ao campo médico e às interações com outros colegas do mesmo campo, os estudantes tendem a supervalorizar os parâmetros morais que pretensamente ${ }^{76}$ eles identificam com a moral médica. Mas deixaremos para aprofundar esta discussão mais adiante. Prossigamos, então, com nosso enfoque no estudante.

Como estávamos interessados em centrar nosso enfoque de análise no estudante de medicina, propusemos a uma faculdade que nos permitisse aplicar uma dinâmica de grupo em um momento de aula. Foi-nos facultado ministrar aula para os alunos do $4^{\circ}$ ano da graduação, divididos em subgrupos, em quatro dias diferentes. Utilizamos uma dinâmica de grupo inspirada em um trabalho consultado através da Internet. ${ }^{77}$ Propusemos à turma que:

- pensasse nas possíveis relações interpessoais que ocorriam no âmbito da faculdade e que envolviam os seguintes atores: professores, alunos, médicos, enfermeiros, equipe de enfermagem, demais membros da equipe de saúde, pacientes, familiares dos pacientes, equipe de apoio do hospital universitário e equipe de apoio da faculdade de medicina;

- pensasse que estávamos ali incumbidos de elaborar as bases de um código de ética que orientasse cada um deles nas diversas relações que se verificavam no âmbito da faculdade de medicina;

- dissessem todos os valores que, segundo sua concepção, deveriam ser assegurados por nosso suposto código de ética e que pudessem ser acatados por todos.

Utilizando a técnica da 'tempestade de idéias' (brain storming), anotamos todos os valores ditos em uma folha de papel vergé que estava afixada na parede. Esta fase durou cerca de 10 minutos, aguardando que tivéssemos de 50 a 60 citações anotadas. Seguimos então ao processo de eliminação de idéias similares

Dizemos pretensamente porque muitas vezes o que os estudantes identificam como 'ética médica' não passa de um entendimento enviesado pelo corporativismo impregnado ao Código de Ética Médica, que, por sua vez, pode estar se transformando, de fato, no senso comum da moral profissional médica.

77 Penitenciamo-nos pela falta de cuidado de não termos anotado a referência deste trabalho para que pudéssemos, aqui, dar o devido crédito. 
e à busca por palavras que sintetizavam dois ou mais valores referidos, deixando sempre que os alunos tivessem total controle do processo, ou seja, acatando toda a decisão que emanava do grupo.

Solicitamos, então, que cada um elaborasse, individualmente, e anotasse em uma folha de papel, uma lista com oito daqueles valores que haviam sido citados anteriormente pelo grupo. A lista deveria contemplar apenas os oito valores que o estudante entendesse que não poderiam estar fora do nosso pretenso código de ética de maneira alguma. Pedimos também que eles anotassem, ao lado de cada valor escolhido, uma observação em relação ao seu entendimento se aquele era um valor absoluto, válido para todas as situações, que não admitia exceção, ou relativo ${ }^{78}$ (ou prima facie).

Finda esta fase, dividimos a turma em subgrupos com até sete membros e pedíamos que cada grupo procurasse elaborar uma lista única de oito valores, que representasse o consenso do grupo sobre os oito indispensáveis, no entender deles, para figurarem no código de ética. Mais uma vez foi solicitado que anotassem o consenso do grupo sobre que valores entendiam ser absolutos e quais seriam relativos (no sentido de prima facie).

Após todos os grupos terem encerrado seus trabalhos, realizávamos uma plenária com relatores de cada grupo e debatíamos tanto a lista e a classificação quanto o processo de discussão que havia ocorrido em cada grupo.

Embora não tenha sido nossa intenção nas aulas, ou mesmo aqui, a realização de um estudo axiológico, mas tão-somente a identificação de alguns dos valores que os alunos consideram importantes para as relações de ensino e de prestação de serviços, não podemos deixar de tecer alguns comentários específicos sobre o tema.

Com a preocupação de evitar considerações mais extensas, optamos por apresentar ao leitor apenas a relação dos valores que foram referidos em todas as quatro turmas em que a dinâmica foi realizada (Quadro 6), pressupondo, assim, um certo consenso sobre eles. ${ }^{79}$

0 sentido adotado aqui para a expressão ‘valor relativo’ não é relacionado ao relativismo moral, mas tão-somente o de que são valores importantes, mas não sem exceções, ou seja, são considerados valores prima facie, não são obrigatoriamente seguidos em todas as situações, já que ocorrem situações de conflito em que um ou outro irá prevalecer sobre os demais.

79 O consenso só poderia ser afirmado de forma peremptória se tivesse sido debatida com o conjunto de estudantes a relação. Embora não verificado na prática, pois não realizamos uma plenária com todas as turmas, o consenso pode ser inferido pelo que observamos nas aulas com cada turma. 
Quadro 6 - Valores referidos em todas as quatro turmas - Brasil, 2000

\begin{tabular}{|c|}
\hline Beneficência \\
Confiabilidade \\
Honestidade \\
Humildade \\
Justiça \\
Paciência \\
Respeito \\
Responsabilidade \\
Solidariedade
\end{tabular}

Fonte: pesquisa desenvolvida pelo autor.

Esta relação de valores não deve ser entendida como um simples enunciado de virtudes, apresentado para satisfazer o desejo de um professor convidado ou para parecer politicamente correto perante seus colegas. 0 desenrolar da dinâmica em todas as turmas foi extremamente rico, diriamos até conflituoso. A maioria dos estudantes de cada turma engajou-se de fato no debate, procurando convencer o grupo de que sua opinião era a melhor ou a mais certa, que os valores por ele escolhidos eram indispensáveis. 0 resultado do processo foi um grande exercício de reconhecimento da diversidade de valores e um exercício de tolerância em relação às diferentes visões de mundo e à busca de negociação.

Um dos alunos, homem, 21 anos, observou, ao final da atividade: "Puxa! Nunca pensei que pudesse ter tanta opinião diferente sobre um tema que me parecia óbvio!". Esta constatação demonstra apenas como praticamente inexistem discussões que envolvam a livre opinião sobre temas que dizem respeito às relações interpessoais na faculdade. Quando existem, os alunos preocupam-se em manifestar-se de acordo com o que acreditam que se espera deles como futuros médicos e o fazem opinando de acordo com o que acreditam estar no Código de Ética; tentam mostrar que estão sendo capazes de incorporar a cultura médica, seus valores e atitudes.

Talvez possamos esperar do aparelho educacional que colabore para que cada indivíduo realize sua revolução coperniciana pessoal: a descoberta do ou- 
tro como também um sujeito. Não estamos pretendendo, com esta abordagem sobre valores, defender uma posição que insinue a existência de um 'saco de virtudes', aos quais a educação poderia contribuir para que os indivíduos as descubram e se convençam de sua relevância. Defendemos que debates sobre o que os alunos valorizam, especialmente nas escolas médicas, contribuirão para o desenvolvimento de sua capacidade cognitiva de usar a razão para discutir a moral.

Considerando que a simulação realizada foi a elaboração de um código de ética, não é de se estranhar que os valores apresentados digam respeito à moralidade do agente. Conforme Schramm (2000: 10), "as teorias deontológicas dizem respeito ao caráter do agente (....) e as teorias teleológicas, ou conseqüencialistas, centram sua atenção (...) na qualidade do que é feito, isto é, na qualidade do ato". Embora, sem dúvida, seja possível supor que uma pessoa 'boa' tenderá a fazer coisas 'boas', a abordagem deontológica "pressupõe uma homogeneidade sociocultural de valores, que em sociedades seculares e pluralistas, nas quais existem diversas concepções do bem e do mal, é muito difícil estabelecer o que é um padrão de virtude ou não" (Schramm, 2000: 10).

Ainda assim, tanto a dinâmica realizada é um exemplo de atividade pedagógica para ser desenvolvida com estudantes da graduação como foi também importante para que conhecêssemos um pouco mais a visão dos estudantes sobre o campo da moral e da ética. Entrando então, especificamente, na discussão sobre a ética na prática profissional, perguntamos em nosso questionário aplicado no Maranhão entre estudantes que participavam do Ecem: "0 que é ser ético no exercício da profissão médica?" e "0 que deve orientar sua atitude no caso de estar diante de uma situação que você identifique como uma questão ética?".

A palavra mais usada pelos estudantes em suas respostas foi 'respeito'. Respeitar o paciente, o Código de Ética Médica, sua consciência, o colega de trabalho, as leis, enfim, o respeito foi pensado como um conceito que permeia o comportamento ético. É claro que nem sempre o respeito deve ser interpretado da mesma maneira, com o mesmo significado, como veremos a seguir, em uma abordagem que dividiremos em tópicos para ficar mais claro, mas a preocupação com o respeito pelos outros foi um dos pontos dominantes das respostas. 


\section{Código de Ética}

Para alguns alunos que, de certa forma, expressam a opinião do então presidente do Cremerj, dr. Abdu Kexfe, "Se os novos médicos seguirem os preceitos do Código de Ética Médica, serão bem sucedidos na profissão” (Jornal do Cremerj, 2000: 20), ser ético é seguir o Código de Ética. Alguns exemplos desta abordagem são: "Não se desviar do Código e exercer a profissão dignamente" (feminino, 19 anos); "Não desrespeitar o Código de Ética” (masculino, 18 anos); "Ser coerente com o Código e analisar cada caso como um novo caso" (masculino, 22 anos); "Agir de acordo com o Código de Ética, respeitando as convenções" (masculino, 22 anos); "Seguir a deontologia, porque, aliado ao bom senso, nos fará fazer a coisa certa" (feminino, 19 anos); "Seguir o Código de Ética, porque assim sei que vou agir corretamente" (feminino, 22 anos).

Para esses alunos, ser ético é a obediência ao Código, a uma verdade que está 'fora' deles; é um modo de entender o raciocínio moral que pode ser comparado àquele descrito por Kohlberg para o estágio 3. É um raciocínio típico, e aqui não existe nenhum juízo de valor de nossa parte, de quem pretende 'se enquadrar na profissão'; diríamos até que representa o raciocínio que, a julgar pelas palavras do presidente do Cremerj, a corporação desejaria para seus futuros membros.

Todavia, como já referimos anteriormente, a realidade de uma sociedade democrática e plural não é contemplada na maioria dos códigos de ética, muito menos no médico. Acreditar que o Código trará respostas a todas as dúvidas e/ ou conflitos que surgirão e que surgem da prática médica é desconhecer a História. Códigos e Leis são o resultado do acúmulo de experiências passadas. Todo código e toda lei tendem a sofrer sempre de uma certa defasagem, já que expressarão sempre o convencionado pela sociedade, não tendo como interferir na evolução dos costumes ou mesmo antecipar as mudanças que ocorrerão na sociedade. Assim, por exemplo, o Código Civil brasileiro, ainda em vigor, trata de forma distinta o adultério feminino do masculino; mas o que era atentado violento ao pudor há algumas décadas está hoje na televisão em horário vespertino. Se no passado, como nos referimos no primeiro capítulo, era proibido aos médicos questionar a imortalidade da alma, hoje, em uma sociedade em processo de secularização, não existe mais uma proibição explícita.

Quando se reforma um Código, seja ele profissional ou não, busca-se adequá-lo ao que se transformou em 'socialmente aceito'. Tomemos, como 
exemplo de análise, a questão do aborto. Embora a maioria das pessoas ainda se manifeste em pesquisas de opinião contrárias ao aborto, sua disseminação em nosso país é um fato incontestável. Cada vez mais um maior número de mulheres abortam voluntariamente e, como muitas o fazem em condições técnicas e de higiene insatisfatórias, este se transformou em um grave problema de saúde pública. ${ }^{80}$ Muitas mulheres manifestam-se publicamente como contrárias ao aborto embora elas próprias já tenham realizado às vezes mais de um. ${ }^{81}$

Contudo, tanto o movimento feminista em defesa do direito ao aborto quanto a maior discussão científica sobre os limites da vida têm possibilitado uma maior compreensão do tema por um número cada vez maior de indivíduos. Não será surpresa para nós, que, em futuro não muito remoto, a legislação sobre o aborto será modificada, tornando-se mais flexível.

Outro exemplo sobre mudanças no Código que pode ser analisado é o que diz respeito às popularmente chamadas 'cirurgias de mudança de sexo'. Até muito pouco tempo, o Código de Ética, que veda a realização de cirurgias mutiladoras, era interpretado como se impedisse a realização dessas cirurgias. No entanto, cada vez mais cirurgiões passaram a admitir a possibilidade de realizarem esta cirurgia. Hoje, a interpretação corrente para o Código não mudou, mas a cirurgia de mudança de sexo passou a não ser mais considerada como uma 'mutilação'.

\section{Primado da Técnica}

Alguns estudantes, minoritários no conjunto entrevistado, parecem inebriados pelo desenvolvimento da ciência e da técnica. São os que acreditam que as respostas aos dilemas morais podem ou devem ser encontrados através do conhecimento técnico, como afirmou a jovem estudante pernambucana: "agir com calma, corretamente, ponderadamente. Tomar a decisão mais correta independentemente do resultado final, embora dever buscar a recuperação do paciente" (feminino, 20 anos). Ou, ainda, sua colega, que preconiza ser ético "fazer a coisa certa, independente de estar prejudicando o outro" (feminino,

\footnotetext{
80 Nunca é demais ressaltar que, para a maioria das mulheres, o aborto não é algo desejado em si mesmo, como se fosse um simples método anticoncepcional, e sim uma dolorosa experiência e decisão tomada em circunstâncias quando esta opção parece ser a única possibilidade, e realmente é.

81 Esta aparente incoerência pode ser explicada pela influência da religião católica no país ou exatamente pelo que afirmamos anteriormente - que o aborto não é algo desejável, mas realizável quando a situação se impõe.
} 
19 anos). Para esses estudantes, parece existir uma verdade científica que encontra justificação para seus atos nela própria, o que, em última análise, faz com que ignorem até mesmo o Código de Ética da corporação.

0 fato de esses estudantes serem minoritários no conjunto por nós entrevistado não significa que sejam menos expressivos no conjunto de médicos em atividade. Aliás, arriscaríamos dizer, pela nossa experiência e a de nossos colegas no funcionamento dos Comitês de Ética em Pesquisa Brasil afora, que um subconjunto não desprezível de médicos envolvido em pesquisas com seres humanos também elegem a ética do conhecimento científico como o fundamento para justificar suas pesquisas, a despeito do mal a que exponham seus pacientes. Logo, antes de desqualificarmos as opiniões dessas estudantes, por minoritárias e por serem jovens, devemos sim estar atentos, pois refletem a lógica predominante em várias mentes médicas brasileiras. Aliás, argumentos semelhantes foram utilizados na tentativa de justificação das pesquisas desenvolvidas por nazistas durante a $2^{\mathrm{a}}$ Guerra Mundial.

\section{Bom Senso e Consciência}

Como já afirmamos anteriormente, para vários estudantes, o que importa é o seu entendimento da moral espontânea. É o que se pode depreender da afirmação desta estudante de 20 anos: "Bom senso. Vale o caráter do médico". Ou da afirmação de outro, de 18 anos, que afirma "Bom senso. Não é seguir o Código necessariamente, já que pode haver casos ambíguos”. Já uma estudante, de 22 anos, estabelece a 'defesa da vida' como um princípio fundacional de sua ética e justifica sua afirmação pelo bom senso "porque não dá prá ficar analisando leis defendendo a saúde do paciente". Outro estudante, também de 22 anos, afirma que "a consciência é que deve orientar suas atitudes, por ser a única coisa que está sempre ao alcance". Outra, com 20 anos, assinala que "minha consciência me orienta por enquanto, porque ainda não tenho uma teoria para explicar o que é ética, mas tenho minha consciência", da mesma maneira que seu colega de 21 anos, que afirmou "minha consciência, porque confio em mim".

Essas afirmações centram a verdade sobre o ‘bem' e o ‘bom' nos próprios indivíduos. Se por um lado é interessante que busquem a reflexão crítica sobre os fatos e acontecimentos que estão vivenciando, por outro, é problemático acreditar que apenas sua consciência será capaz de orientá-los na escolha da decisão melhor para ‘o outro’. 
Apostar na consciência sem explicitar que serão avaliados os interesses do outro, através de seu entendimento sobre os fatos e da consideração dos valores e interesses da forma como este o manifesta, é o que se convencionou chamar de 'paternalismo'. ${ }^{82}$ Age-se como um pai que, por saber o que é melhor para o filho, toma as decisões em seu lugar.

Houve também quem identificasse especificamente em sua formação desde a infância, através da socialização primária, as bases para seu bom senso, como um rapaz de 21 anos: "Bom senso, porque os principais conceitos de ética e respeito com os outros estão na nossa cabeça desde a infância e no convívio familiar. Não é um código que vai me fazer mudar de atitude ou me vigiar”. No mesmo sentido está este outro depoimento: “a minha formação profissional e a educação que recebemos em casa” (masculino, 22 anos). Como já afirmamos anteriormente, o sucesso da socialização secundária, no caso, a profissional, dependerá de sua harmonia com os conteúdos da socialização primária, como esses rapazes bem assinalaram.

Notemos que, até agora, sempre que os estudantes se referiam à consciência ou ao bom senso, estavam buscando a 'verdade' ou o 'bem' em si próprios. Outros, entretanto, admitem 'checar' a sua verdade com o que chamamos de moral convencional, como um estudante, de 28 anos, que afirmou "primeiro penso na minha verdade e a comparo com a situação e a verdade coletiva”.

0 papel que a escola médica tem a desempenhar no processo de ajudar os estudantes a reconhecer situações dilemáticas ou, no mínimo, que demandam um posicionamento ético deles, é apontado e implicitamente criticado em diversas das respostas obtidas. Desde o estudante que alega utilizar o bom senso "porque até mesmo os professores que deveriam passar noções de ética, não as têm como ponto de orientação; por isso, na medida do possivel, tendo a usar o meu bom senso" (masculino, 22 anos) à estudante que alega que o que deveria orientar suas atitudes são "os princípios éticos que deveriam ser colocados durante a minha formação, pois é o papel da escola estimular nossa reflexão" (feminino, 22 anos).

Note-se que 'o outro', em todas essas abordagens, é um elemento passivo. Objeto do trabalho e da preocupação do estudante, mas não um sujeito reconhecido como tal.

${ }^{82}$ Para maiores informações sobre paternalismo, ver Häyry (1998). 


\section{O Raciocínio Moral Instrumental}

0 exemplo do que Kohlberg apresentou como o estágio de trocas instrumentais $^{83}$ - "o que eu fizer para alguém deverá reverter em benefício para mim" - também pode ser encontrado em nossas entrevistas. Por exemplo, uma estudante de 19 anos assinalou que o respeito ao paciente é o que orienta suas atitudes "porque o exercício de nossa profissão é o paciente, se não tratá-los bem, que benefícios teremos?"; outra estudante, de 20 anos, afirmou "tomar a decisão que for melhor para mim e para o meu paciente".

Essas opiniões podem também ser interpretadas confrontando-as à concepção do ideal de serviço, ao que fizemos referência no início deste capítulo e que sustenta e legitima a autoridade social das profissões. Não é novidade para os que convivem com profissionais das mais diferentes formações que cada vez torna-se mais dificil que eles ajam dessa forma - mas isso seria assunto para uma análise sociológica que é despropositada aqui.

\section{Moral Convencional Médica ${ }^{84}$}

Alguns estudantes manifestaram uma preocupação em identificarem o comportamento ético como a negação e a mercantilização da medicina, assumindo, assim, que ser ético é: "usar o diploma corretamente, respeitar o paciente, ajudá-lo e não usar a profissão para outros fins, por exemplo, financeiros" (feminino, 20 anos); "não se prostituir para alcançar um objetivo que não vá ao encontro dos ideais médicos" (masculino, 25 anos); "não ser mercantilista. Não esconder do paciente sua doença, não prejudicar o paciente com o objetivo de se promover pessoalmente" (feminino, 19 anos); "agir com a consciência limpa e isento de qualquer possibilidade de culpa e não fazer da saúde um meio de exploração econômica, política e de qualquer intenção que não seja em prol da saúde" (masculino, 21 anos).

Os exemplos apontados reforçam a concepção do ideal de serviço, por negarem a possibilidade de o benefício econômico do médico ser a justificativa para a decisão médica, e inserem-se no contexto da moral tradicional médica.

Estágio 2, Nível 1.

Estamos usando aqui 'convencional' tanto no sentido de tradicional quanto no conferido no capítulo 3, na descrição do estágio 3, Nível 2. 
Outras manifestações observadas dessa moral tradicional, e o tradicional aqui não é usado como ultrapassado ou algo a ser substituído, são as respostas que apontam os princípios morais de beneficência e/ou não maleficência como guias condutores de atitude. Como Schramm apontou, "a ética médica baseia-se em dois deveres absolutos, considerados necessários e suficientes para determinar se o agir médico é ou não correto, e que são constitutivos da assim chamada 'deontologia médica'; trata-se dos deveres de não maleficência (primum nihil nocere) e de beneficência (bonum facere)" (Schramm, 2000: 8). Assim, esses estudantes, ao enfatizar aqueles princípios, o fazem de forma a situar neles próprios, em uma posição consonante com a deontologia, a decisão sobre o que é o ‘bem' ou o 'bom'.

Mas nem todos os estudantes por nós entrevistados manifestaram-se sobre estes princípios da mesma maneira, como podemos ver nos exemplos a seguir: "ser ético é não causar dano e buscar a beneficência, respeitando a autonomia do paciente. É tratar o paciente como um todo e humanizar a relação médico paciente" (feminino, 20 anos); "ser ético é ter noção do que é certo e errado, lícito e ilícito. É a sabedoria prática de se buscar sempre o melhor para o paciente sem sacrificar o respeito e a autonomia dele" (feminino, 19 anos); "ser ético é saber respeitar os direitos dos outros, saber ouvir, mas, principalmente, exercer a profissão de modo a beneficiar sempre quem lhe procura, ouvindo o paciente" (feminino, 25 anos); "ser ético é agir de modo a respeitar o indivíduo, não colocando como dele as suas verdades e convicções" (masculino, 21 anos).

Esses alunos abordam os mesmos princípios que os outros, mas referem-se também ao reconhecimento do outro como sujeito moral, com suas verdades, valores e crenças. São particularmente interessantes esses depoimentos por não resvalarem para a falsa comodidade de se atribuir, à autonomia do paciente, um caráter absoluto, como se este pudesse ser, por sua vez, um valor ou um princípio que se sobreponha aos outros. A autonomia não é e, em nosso entendimento, não pode vir a ser considerada um princípio moral absoluto, ${ }^{85}$ devendo ser levada em conta no dia-a-dia da prática em saúde, em conjunto com outros princípios. ${ }^{86}$

Sobre a complexidade do princípio da autonomia e de sua aplicação prática nas relações na área da saúde, ver Schramm (1998). Sobre a complexidade do ensino da autonomia para estudantes de medicina, ver Kottow (2000).

${ }_{86}$ Sobre o principialismo na bioética, ver Engelhardt Jr. (1996). 


\section{Defesa dos Colegas de Profissão}

Existe também uma interpretação do que seja a ética no exercício profissional que consideramos uma das maiores expressões de defesa da corporação - a compreensão de que a ética médica existe para proteger o médico.

Está certo que o Código de Ética Médica, como qualquer outro código, possui mecanismos de proteção profissional. Um desses mecanismos é considerado por muitos sociólogos uma etapa fundamental no processo de profissionalização das ocupações, ou seja, uma etapa que toda ocupação necessita alcançar para se profissionalizar. Estamos nos referindo à auto-regulação profissional. Esta é a competência, conferida pelo Estado, aos integrantes de uma ocupação de se auto-regularem, de julgarem-se a si próprios e determinarem as eventuais punições pelos desvios. Um dos instrumentos desta auto-regulação é o Código de Ética, na medida em que estabelece direitos e deveres profissionais e algumas outras normas de convivio social no interior da corporação, como se comportar no caso de atender o paciente de um colega, quando chamado para uma conferência médica etc.

A interpretação de que um dos objetivos da ética é a proteção do colega, o que leva ao comportamento de não criticar outro médico, ainda que ele esteja errado, decorre da cultura médica e de prescrições de códigos de ética antigos, nos quais este comportamento era previsto e representava mais um dos deveres do médico.

A primeira proibição de emitir comentários desfavoráveis a outro colega em público está no Código de Deontologia Médica, de 1945, que, em seu artigo 10, vedava ao médico: "quando em visita de amizade ou social a doente assistido por um colega, fazer comentários prejudiciais ao assistente” (Martin, 1993: 347). Já no Código de Ética da Associação Médica Brasileira, de 1953, mantinha-se a restrição do anterior e acrescentou-se, em seu artigo 7º, capítulo sobre 'relações com colegas', que “o médico deve ter para com seus colegas a consideração, o apreço e a solidariedade que refletem a harmonia da classe e lhe aumentam o conceito público". 0 artigo seguinte explicitava a questão ao afirmar que "o espírito de solidariedade não pode, entretanto, induzir o médico a ser conivente com o erro, ou deixar de combater os atos que infringem os postulados éticos ou disposições legais que regem o exercício da profissão; a crítica de tais erros ou atos não deverá, porém, ser feita de público" (Martin, 1993: 359). Este artigo repetiu-se no Código de 1965 (1993: 371) e só foi retirado do Código em 1984. 
No atual Código, de 1988, no capítulo Vll, 'Relações entre Médicos', o comportamento vedado é o de "acobertar erro ou conduta antiética de médico" (Martin, 1993: 394). Todavia, a antiga concepção de que não se deve criticar a conduta de outro médico ainda está presente não apenas entre os profissionais que exerceram a profissão durante a vigência daqueles códigos, como também na opinião dos estudantes: "respeitar o colega de trabalho" (masculino, 23 anos); "preservar a integridade do paciente, mas também respeitando os colegas de profissão" (feminino, 20 anos); "ter bom senso, não prejudicando o paciente, os colegas ou a si mesmo"(feminino, 19 anos).

\section{Qualidade de Vida}

Alguns estudantes demonstram ter uma compreensão mais ampla de sua função profissional, incorporando, em suas definições sobre o que é ser ético e na fundamentação de suas atitudes, o conceito de 'qualidade de vida'. ${ }^{87}$ Libertando-se do antigo conceito de que o fundamental era salvar a vida do indivíduo e voltando sua atenção e seu raciocínio para a preocupação sobre as conseqüências de sua ação para o indivíduo que está sendo objeto dela, estes alunos demonstram inequivocamente uma preocupação ética com seus pacientes. É o que se observa na resposta desta estudante de 20 anos do Ceará: "preservar a vida e a qualidade desta vida". Esta frase, com pequenas variações, foi escrita por outros entrevistados de Pernambuco e Rio Grande do Sul.

\section{Máxima do Cristianismo}

Alguns estudantes, por sua vez, conscientes disso ou não, fundamentam sua compreensão sobre a ética na chamada 'regra de ouro' do cristianismo: faça ao próximo aquilo que gostaria que fosse feito a você mesmo. Esse posicionamento não deve ser confundido com aquele descrito por Kohlberg para o estágio 2, de trocas instrumentais. Naquele, a perspectiva é individualista, o benefício está voltado para o indivíduo e não para o outro. 0 benefício ao outro só existe na possibilidade de haver um ganho imediato concreto para o indivíduo. Aqui não, compreende-se que há uma preocupação concreta com

0 princípio da qualidade de vida muitas vezes se confunde com a própria bioética e está em oposição ao princípio da sacralidade da vida entendida como um princípio absoluto que não admite exceções. Ver Mori (1994). 
o outro, razão pela qual também entendemos este posicionamento como compativel com a moralidade convencional.

Exemplos desse posicionamento podem ser vistos nos seguintes casos: "ser ético é se pôr no lugar das pessoas e fazer o que gostaria que fosse feito com você" (feminino, 20 anos), ou "é tratar todos como você gostaria de ser tratado" (feminino, 21 anos), ou ainda "coloco-me na posição do paciente, no tocante à sua doença e conseqüências psicossomáticas, porque uma pessoa bem de saúde comporta-se diferente de uma enferma e mesmo as pessoas normais podem entrar em situação de estresse" (masculino, 26 anos).

Podemos também depreender desses depoimentos que, mais uma vez, os estudantes, ao se 'colocarem no lugar do paciente', estão repetindo aquele comportamento, já descrito anteriormente por nós, em que é negada ao paciente sua condição de sujeito moral. Colocar-se no lugar do outro é o exemplo mais claro da utilização de seus valores e de sua análise da situação para tomar uma decisão relacionada a um terceiro, que só é considerado como alvo de sua ação moral, jamais como sujeito moral.

Nos Estados Unidos, em 1991, após a realização de algumas oficinas de trabalho, a American Association of Medical Colleges (AAMC) publicou um documento no qual manifestou algumas de suas preocupações sobre os valores entre os estudantes de medicina. Neste documento, foi relatada a existência de uma proporção sem precedentes de indivíduos na então geração de estudantes que "adotavam atitudes e comportamentos que subordinavam os tradicionais princípios morais de honestidade, respeito pelos outros, responsabilidade pessoal e dever cívico a valores autocentrados que acentuam o materialismo e a competitividade pelo sucesso" (Bickel, 1991: 726). Ainda que as conclusões do documento sobre as causas dessa mudança sejam, a rigor, ideologicamente determinadas e profundamente equivocadas - atribuem-na à secularização da sociedade e ao aumento de imigrantes nas escolas -, sua preocupação expressa um sentimento que há muitos anos também vem sendo percebido entre os que trabalham, seja na formação, seja na gestão de profissionais de saúde, e que poderiamos sintetizar como desumanização da assistência.

Após esse panorama geral, fruto de uma investigação exploratória e, portanto, não necessariamente representativa de toda a diversidade de pensamentos que certamente povoa corações e mentes dos estudantes de medicina no Brasil, podemos passar a uma descrição das diversas situações vividas nas quais eles identificaram questões éticas. Essas situações podem e devem ser usadas para 
discussões sobre ética em salas de aula. Cada uma delas, como veremos, está diretamente relacionada ao cotidiano dos alunos e à sua capacidade de avaliar e de tomar decisões sobre questões éticas. 



\section{A Vivência de Situações Envolvendo Questões Éticas}

Em uma crônica publicada em agosto do ano 2000, o médico Drauzio Varela abordou o problema das filas na porta dos hospitais públicos. Nela, o laureado médico, famoso por seu trabalho social na penitenciária do Carandirú em São Paulo, descreveu cenas do seu cotidiano como estudante na década de 60 e as comparou com a situação atual, no que se refere às filas; concluiu, dizendo que

talvez a explicação mais sensata para o tamanho das filas e do sofrimento imposto aos pacientes constrangidos a utilizar o sistema público de saúde no Brasil seja outra: os responsáveis pela organização do atendimento médico gratuito não dependem dele. (Varela, 2000: 10)

Sem dúvida alguma, o problema das filas é extremamente grave e merecedor da atenção de todos os que se preocupam com a dignidade dos usuários do setor público, mas, para introduzir o tema, o articulista assim descreveu seus tempos de estudante, infelizmente, sem outras referências, comentários ou comparações:

No meu tempo de faculdade, a maioria dos professores falava num tom educado com os alunos e elevava a voz para fazer perguntas ao doente, na cama. As mulheres todas eram dona Maria e os homens, seu Zé, sem exceção. No início, os alunos ficavam chocados, mas, com o passar do tempo, boa parte adotava a estupidez dos mais velhos como norma de conduta. Naquele tempo, as mocinhas que chegavam ao pronto-socorro do Hospital das Clínicas com sangramento ginecológico provocado por abortos clandestinos eram submetidas à curetagem uterina sem anestesia. Os chefes de serviço justificavam esse procedimento (...), dizendo que se dessem anestesia o pronto-socorro ficaria mais lotado ainda. Nós (...) obedeciamos como cordeiros às ordens superiores de curetar a sangue-frio. (Varela, 2000: 10)

0 articulista expressou, com rara propriedade, o sentimento de muitos dos estudantes de medicina, nos tempos de hoje como no passado, de impo- 
tência diante dos abusos cometidos por seus professores e, com o passar do tempo, assimilação dos comportamentos desviantes.

Insistimos que esse comportamento desviante é fruto da 'coisificação' do paciente do setor público, especialmente, mas não exclusivamente, já que, nos tempos atuais, o comportamento desviante vem repetindo-se mesmo em clínicas privadas vinculadas ao sistema de saúde complementar, onde a relação médico-paciente é intermediada pela figura do convênio de saúde. Essa 'coisificação' do paciente, em que todos são dona Maria ou seu Zé, em que ninguém tem sua individualidade respeitada ou mesmo considerada, será também possivel observar nos depoimentos que colhemos entre nossos estudantes.

Nossas perguntas sobre esse tema foram: 'Você já viveu ou testemunhou, na faculdade ou em estágios, alguma situação em que uma questão ética estava colocada? 0 que aconteceu? 0 que você fez? Por quê?' De nossos 72 estudantes entrevistados, 29 negaram já ter tido esta experiência.

Como a capacidade de identificar uma situação que envolva decisão ética é também uma questão cognitiva, uma vez que não se poderia reconhecer algo sobre o qual não se tenha conhecimento, imaginamos que haveria alguma correlação entre o reconhecimento das situações e o fato de já ter tido aula de ética. Entretanto, não foi isso que observamos. A chance de essa associação na população estudada ter sido fruto do acaso foi de 31,5\%. Tal fato tanto pode significar que não há essa relação e, neste caso, atribuiriamos este fenômeno ao modelo, ao conteúdo e às técnicas de ensino habitualmente utilizadas nos cursos de Ética/Deontologia na maioria das faculdades brasileiras, como também ser justificado pelo fato de não termos trabalhado com uma amostra representativa da população de estudantes, já que pouco mais de 50\% ainda estava cursando o ciclo básico. Por serem inconclusivos os dados que obtivemos, a hipótese básica permanece, sendo recomendado que se realizem outros estudos, preferencialmente com estudantes da mesma escola, para que se esclareça esta hipótese. Outra hipótese que não foi possível ser testada foi em relação ao gênero. Tínhamos também uma hipótese, que feministas podem considerar sexista, de que as estudantes do sexo feminino identificariam com maior probabilidade situações éticas, mas não foi comprovada, podendo ser igualmente explicada tanto pelas características da população estudada quanto por não haver esta relação. A hipótese permanece, portanto, como a anterior, não respondida.

Outra hipótese que norteou nosso trabalho era a de que os estudantes de medicina teriam mais facilidade para identificar situações éticas relacionadas 
ao atendimento médico, o que determinaria uma maior freqüência dessas descrições entre os alunos que freqüentavam o ciclo profissional do curso, quando o contato com pacientes e com o cotidiano da assistência à saúde é mais freqüente. Esta hipótese foi confirmada, a probabilidade da associação observada ter sido fruto do acaso foi de $0,01 \%$, conforme pode ser verificado na Tabela 1 .

Tabela 1 - Alunos que já vivenciaram questão ética segundo o ciclo do curso que estão freqüentando - Maranhão, 2000

\begin{tabular}{lccc}
\hline Ciclo & \multicolumn{2}{c}{ Viveu questão ética? } & \\
\hline Não & Sim & Total \\
\hline Básico & 30 & 10 & 40 \\
\hline Profissional & $75 \%$ & $25 \%$ & $54,8 \%$ \\
\hline & $10 \%$ & $30,3 \%$ & 33 \\
\hline ToTAL & $30,3 \%$ & 23 & $45,2 \%$ \\
\hline & $25 \%$ & $69,7 \%$ & 73 \\
\hline
\end{tabular}

$p=0,00013404$

Fonte: pesquisa desenvolvida pelo autor.

Podemos classificar as situações identificadas pelos entrevistados como envolvendo 'questões éticas' em quatro grandes grupos: as que envolvem relações professor/médico-aluno em situações de ensino; as relações professor/médicoaluno em situações de assistência; as relações médico/professor/outros profissionais e as relações médico/professor ou estudante e os pacientes.

Essa classificação por tipo de situações é interessante por permitir um reconhecimento delas e a preparação para intervenções pedagógicas e administrativas no âmbito da escola, mas pouco nos ajuda a aprofundar o universo do pensamento moral do estudante de medicina.

Outro tipo de classificação possível seria semelhante à realizada por Christakis \& Feudtner (1993), identificando os dilemas propriamente ditos. 
No caso específico deste trabalho, a classificação utilizada foi: realização de procedimentos médicos, ser parte da equipe, desafiar a rotina médica, conhecer o paciente como pessoa e testemunhar comportamento antiético. Essa classificação, por eles mesmo considerada preliminar, só tem sentido para nós para uma comparação com os resultados que obtivemos, com o objetivo de verificarmos se os problemas observados nas escolas americanas são, de alguma forma, semelhantes aos nossos. Caso encontremos essa semelhança, poderemos construir uma hipótese que busque explicar o fato de realidades sociais tão díspares, como a brasileira e a americana, submeterem seus estudantes de medicina a situações com questões éticas semelhantes. Assim, procuraremos ressaltar inicialmente os aspectos específicos dos problemas entre professores e alunos para, em seguida, construirmos nossa proposta taxonômica.

\section{Relação do Professor ou do Médico com o Aluno em Situações de Ensino}

A relação entre professores e alunos é, ou deveria ser, baseada no respeito mútuo e na preocupação consciente do professor sobre que influência terá sobre o aluno e em suas atitudes após a graduação. No entanto, poucos são aqueles envolvidos com o processo de ensino que possuem uma formação adequada para exercer a função.

Ainda que nos últimos anos tenha havido uma preocupação crescente do Ministério da Educação em cobrar uma titulação que habilite e credencie os docentes, muitos ainda são, a despeito de títulos, despreparados para exercer esta função.

Durante muitos anos, acreditou-se, e ainda há quem acredite em nosso país, que bastava ser um bom profissional, tecnicamente competente e atualizado para ser um bom professor. Se antes da criação de cursos de pós-graduação stricto sensu no Brasil este comportamento ou expectativa ainda podia ser aceitável, pela falta de opções e de conhecimento sobre métodos e técnicas pedagógicas, após o desenvolvimento desta modalidade de ensino aplicado à medicina não é mais.

Entretanto, a maioria dos programas existentes, a despeito das avaliações de produtividade realizadas pelo MEC, não está voltada para a formação do docente de graduação. Muito pouca ênfase é dada à pedagogia, métodos e técnicas de ensino e prática pedagógica. 
Embora reconheçamos que o relacionamento entre professores e alunos seja potencialmente conflituoso, atualmente é comum no discurso dos estudantes universitários em geral uma crítica ao autoritarismo 'exagerado' entre professores, que dispõem da vida de seus alunos sem nenhuma preocupação de terem uma ação educativa.

É o caso descrito por um aluno que registrou o seguinte fato ocorrido em sua faculdade: "uma professora pediu à representante de turma para mudar a data de uma prova. A aluna avisou a mudança, mas a professora mudou novamente a data na véspera e disse: "quem mandou vocês confiarem nela?" (masculino, 22 anos).

Outros dois alunos abordaram o mesmo tipo de problema, mas de forma mais genérica: "desrespeito dos professores com os alunos e falta de compromisso com a qualidade do ensino médico" (masculino, 21 anos) e "na faculdade há dois professores de atitudes e comportamentos incompatíveis com as necessidades de ensino. São grosseiros, não respeitam os alunos" (masculino, 21 anos).

0 desrespeito ao aluno, que muitos estudantes, como o do caso a seguir, apontam simplesmente com um "tem professores que gostam de sacanear o estudante”, também ocorre quando, aparentemente, o professor pode parecer querer ajudar o estudante a avançar em seu processo de socialização profissional.

É o caso, por exemplo, referido por um aluno do $4^{\circ}$ ano, com 21 anos, que recebeu de um professor a tarefa de comunicar um óbito aos familiares de um paciente. 0 aluno ainda tentou argumentar dizendo que nunca tinha feito isso e se não era possível ir alguém com ele, mas o professor, inflexível, disse: "Você pensa que medicina é só sucesso? Vai lá pra aprender a dar as más notícias".

Independente de o professor estar bem intencionado ou não, o que pode ser discutível, é inegável o fato de sua conduta ser inapropriada, tanto para a educação do estudante quanto em relação ao respeito à família do paciente. Mas é comum atribuir-se a estudantes tarefas potencialmente desagradáveis ou desgastantes com o argumento de que é para melhor prepará-los para a vida profissional. Na maioria das vezes, como demonstram alguns estudos sobre a saúde mental dos estudantes de medicina, o resultado é apenas o estresse desnecessário e o aumento do sofrimento mental, inclusive com o 
aumento no risco de suicídio nesta população (Meleiro, 1998; Milan et al., 1999), abuso de drogas, de uso do álcool e de depressão e ansiedade (Shapiro et al., 2000). ${ }^{88}$

\section{Relação entre Colegas}

Não é novidade para ninguém que o curso médico pressupõe intensa competição entre estudantes. Esta competição, iniciada desde o vestibular, sem dúvida um dos concursos de acesso mais difíceis, tanto pela relação candidato/ vaga como pela qualificação dos postulantes, prossegue durante o curso, em busca de privilégios na obtenção de estágios e na preparação para o que podemos chamar de um segundo vestibular - os concursos para a residência médica.

0 curso médico, como tradicionalmente ocorre em nosso sistema educacional, incentiva esta competição e não se esforça para construir uma atmosfera de cooperação e de trabalho em equipe. ${ }^{89}$ Alguns de nossos entrevistados assinalaram situações em que a competição exacerbada deu origem a comportamentos desonestos. Vejamos duas situações exemplares.

- Caso 1: "os editais de concursos públicos somem das paredes da faculdade" (masculino, 21 anos).

- Caso 2: "a troca de favores nos trabalhos científicos. Coloca-se o nome em trabalhos científicos que não se fez só por ‘sobrar' vaga” (masculino, 22 anos).

0 primeiro caso não parece guardar nenhuma especificidade com o curso médico. Parece-nos mais um problema geral, reflexo da deterioração de valores, como honestidade e competição leal, na sociedade como um todo. Já o segundo caso está intimamente vinculado à prática nos meios acadêmicos ligados à área da saúde. É uma prática, por exemplo, no meio acadêmico médico, a inclusão do nome do chefe do serviço num trabalho científico que tenha sido feito, como um dos autores, como já foi comum a inclusão de todo o corpo

88 Estes trabalhos referem-se a estudos epidemiológicos comparando-se dados de incidência e prevalência de estresse, depressão, ansiedade e suicídio entre estudantes de medicina e segmentos da população em geral. Como Shapiro afirma, "o curso médico tem conseqüências deletérias para os alunos" (Shapiro \& Miller, 1994: 591). Embora nenhum dos trabalhos tenha feito referência a este tipo de 'pequenas maldades', não temos dúvida de que elas contribuem para tornar o curso médico potencialmente perigoso para alguns alunos em especial.

89 Uma exceção parecem ser os cursos organizados de acordo com o Problem Based learning (PBL), nos quais o aprendizado em equipe e em situações de cooperação é mais freqüente. 
médico do mesmo serviço. Um dos reflexos desta prática é o descomunal volume de publicações que médicos em geral possuem em comparação com seus colegas de áreas como a saúde coletiva ou pesquisadores com outras formações acadêmicas.

De tão comum e de tanto abuso que já se cometeu com esta prática, as revistas médicas científicas mais respeitadas internacionalmente, como o The New England Journal e o Journal of the American Medical Association, incluiram em suas normas de publicação uma limitação no número de possíveis autores de um trabalho (quatro). ${ }^{90}$

\section{Relação com Pacientes: será que estamos ensinando aos estudantes que os pacientes não importam? ${ }^{91}$}

Como afirmamos, inicialmente tínhamos pensado em classificar os episódios relatados pelos estudantes de acordo com as situações específicas em que eles estavam inseridos, quais sejam, situações de ensino ou de assistência. Entendemos, entretanto, que, por mais que seja interessante esta divisão, para fins de um melhor entendimento de como as situações surgem no contexto da formação profissional, esta não era a melhor abordagem. Estariamos dando, daquela forma, ênfase ao processo de ensino que deveria estar sendo conferida aos fatos em si, e não tanto às circunstâncias. De todo modo, procuramos preservar no relato dos casos as referências eventuais ao contexto, de forma que o leitor poderá se situar também em relação a este aspecto.

Apesar do propósito classificatório, é preciso ressaltar que a inclusão de um caso em uma ou outra 'categoria' não é inflexível, ou seja, a maioria dos casos poderia estar em diversas 'categorias' e nossa escolha foi arbitrária, no sentido de oferecer ao leitor um panorama da forma mais geral possível.

Assim, classificaremos os episódios referidos em: Conflitos éticos clássicos; Aspectos éticos relacionados ao sigilo profissional: confidencialidade no exercício profissional; Conflitos éticos relacionados com aspectos da política de saúde: justiça; Aspectos éticos relacionados ao uso do cadáver humano no aprendizado profissional; 'Pequenas' grandes maldades na prática profissional; Preconceito social; Desrespeito à pessoa: coisificação do ser.

Quando este número for excedido, deve haver uma explanação do que cada autor fez no trabalho. Aliás, introduzimos a mesma exigência nas normas de publicação da Revista Brasileira de Educação Médica.

91 Este é o título de um artigo publicado por Jean Robinson, representante leiga no General Medical Council da Inglaterra: “Are we teaching students that patients don’t matter?" (Robinson, 1985). 


\section{Conflitos Éticos Clássicos}

Aqui estão incluídos os dilemas éticos mais habitualmente referidos na literatura, e que, em geral, expressam situações de conflito entre a autonomia do indivíduo e o entendimento médico tradicional do que seja o melhor ou o mais certo para o paciente. São os casos citados que se referem a pacientes testemunhas de Jeová e à administração de sangue como parte da terapia e o direito do aborto.

Incluiríamos aqui, embora não tenham sido citados, os casos de eutanásia e doação de órgãos, por exemplo. Este conjunto de casos, aliás, são os que mais freqüentemente são usados como exemplos em salas de aula, embora dificilmente a participação do estudante possa ser mais abstrata, já que ele não terá nunca a responsabilidade ou a atribuição, enquanto tal, para atuar em casos como esses.

Apesar de Christakis \& Feudtner (1993), por exemplo, questionarem a validade da utilização desse tipo de caso, entendemos que exatamente por serem casos mais clássicos e, portanto, já com muita reflexão acumulada sobre as situações, podem ser sim de grande utilidade em eventuais discussões com fins educacionais.

Vejamos alguns casos que foram referidos pelos estudantes e que demonstram o seu distanciamento, embora também possam ajudar o docente a preparar um caso para discussão em sala de aula:

- Caso 1: "Paciente com hepatopatia avançada e testemunha de Jeová, necessitando de transplante de fígado" (masculino, 21 anos).

- Caso 2: "Questão da não-aceitação de tratamentos com uso de sangue (transfusão total ou parcial) por parte de Testemunha de Jeová, diante do pedido de inclusão desse tipo de tratamento pelo médico. 0 médico resolveu por não aceitar a recusa da Testemunha de Jeová. Ficaram perante a autonomia e o princípio da beneficência” (feminino, 19 anos).

- Caso 3: "A mulher fez um aborto e chegou no pronto-socorro sangrando muito e nervosa. Aí o médico disse pra ela: 'Na hora de fazer achou bom né, agora agüenta - eu devia deixar você sangrando"” (feminino, 22 anos).

- Caso 4: "No Hospital do Pronto-socorro, no estágio do internato, eu acompanhava um paciente com doença pulmonar obstrutiva crônica 
com indicação de ventilação mecânica. Porém, a Unidade de Terapia Intensiva estava lotada e tivemos de decidir entre colocá-lo ou retirar outro paciente" (feminino, 22 anos).

\section{Aspectos Éticos Relacionados ao Sigilo Profissional: confidencialidade no exercício profissional}

- Caso 1: "Um médico de um hospital da rede SUS em Pernambuco (interior), que se encontrava no período de seu plantão, informou ao pai de um jovem de aproximadamente 25 anos que este precisava fazer uns exames para detectar HIV. 0 pai, preocupado, perguntou o porquê e o médico lhe disse que o jovem lhe confessou que era homossexual e tinha medo de pertencer ao grupo de risco" (feminino, 22 anos).

- Caso 2: "0 professor ficava discutindo o prognóstico sombrio de $\mathrm{CA}^{92}$ na frente de todo mundo na enfermaria" (feminino, 20 anos).

Os dois casos aqui descritos envolvem a questão da confidencialidade. É um dos valores profissionais mais tradicionais e é previsto em todos os Códigos de Ética Médica que o Brasil já teve, respeitando a tradição que vem do Juramento de Hipócrates. Em princípio, tudo que é dito para o médico em uma relação profissional deve ser mantido em sigilo até mesmo perante o Estado, salvo decisão judicial. 0 que está em questão aqui é o direito do indivíduo de não ter informações sobre sua privacidade divulgadas sem o seu devido consentimento.

Nos dois casos, os médicos parecem ter desconsiderado este direito e, pelas situações brevemente descritas, podemos supor que tenham sido pelas próprias caracteristicas dos pacientes: um era homossexual e o outro um paciente de um hospital de ensino.

Como veremos mais adiante, nem sempre certas categorias de pacientes são respeitadas como pessoas e cidadãos. A situação descrita no segundo caso é típica das situações de ensino em nossos hospitais: nas visitas coletivas às enfermarias, ou rounds, como algumas faculdades se referem. Nessas visitas, os casos são relatados na presença de estudantes, docentes, residentes e médicos responsáveis pelos casos sem que haja uma preocupação com o sigilo das infor-

É comum a utilização, no meio médico, de acrônimos, especialmente na frente de pacientes, como uma estratégia para a discussão de hipóteses diagnósticas ou diagnósticos sem que o paciente entenda. No caso, CA significa Câncer, para o qual também é usado o prefixo NEO, de neoplasia. Outro exemplo é BK, que é a sigla de Bacilo de Koch, agente etiológico da Tuberculose. 
mações já que além dos demais pacientes internados na mesma enfermaria não é raro que haja parentes ou acompanhantes também presentes. Nessas situações também, muitas vezes, os pacientes são despidos e examinados sem que uma preocupação maior com a privacidade deles seja observada.

\section{Conflitos Éticos Relacionados com Aspectos da Política de Saúde: justiça}

- Caso 1: "Na enfermaria de gastro, uma senhora bastante idosa precisava da colocação de uma prótese que (sic) o hospital não autorizou a compra. Quando consultada, a paciente afirmou que gostaria de aumentar sua sobrevida (o caso era grave), porém, a família, que tinha recursos, não autorizou a compra da prótese via particular ( $R \$ 200,00)$. A equipe da enfermaria, depois de esgotadas todas as possibilidades de adquirir a prótese pelo SUS, fez uma 'vaquinha' para comprar a prótese" (feminino, 22 anos).

- Caso 2: "Há vários casos de médicos de uma especialidade terem de atender casos de outra, pela falta de especialistas" (feminino, 19 anos).

- Caso 3: "Uma paciente minha do ambulatório precisa fazer uma angioplastia com colocação de stent, mas o hospital não tem dinheiro para comprá-lo. 0 serviço de cardiologia me orientou para colocar a situação para a paciente e dizer para ela quanto custa o stent para que ela o compre. Não concordo que a saúde seja equiparada a mercadoria" (masculino, 26 anos).

Vivemos em um país onde a questão da disponibilidade de recursos financeiros é extremamente problemática, não apenas pela sua tradicional e real escassez, como por uma tradição de sua utilização em benefício de parcelas minoritárias da população.

A luta empreendida por setores da população ao longo dos últimos 60 anos pela universalização do direito à saúde e pela eqüidade, cuja conquista foi formalizada com a promulgação da Constituição de 1988 e com a criação do Sistema Único de Saúde, não foi capaz ainda de superar as contradições na alocação de recursos geridos pelo Estado. Entretanto, ainda que fosse possível uma alocação de recursos substancialmente mais significativos no setor saúde, ainda assim haveria escassez. 
Lidar com a escassez de recursos é um problema para qualquer adulto consciente e que anseie por critérios de justiça. Mas, é ainda mais conflituoso para um adolescente ou adulto jovem, desejoso de salvar vidas e aumentar a sobrevida de seus pacientes, deparar-se com limites de ordem financeira que não são, em momento algum, discutidos com eles ou com quer que seja.

As decisões sobre o que um hospital cobrirá em um atendimento específico podem, às vezes, estar mais relacionadas ao poder de barganha e de negociação que os chefes de clínica possuam junto à direção do hospital do que às necessidades objetivas deste ou daquele paciente.

A definição de prioridades e a disponibilização de recursos para o atendimento destas prioridades são, via de regra, obscuras para a maioria dos profissionais envolvidos no atendimento, quanto mais para os estudantes. 0 mesmo recurso que foi negado para o pagamento da prótese do caso 1 pode ter sido liberado para a compra de uma televisão a cores para o quarto dos plantonistas, gasto em um almoço com autoridades ministeriais ou ainda doado para a viagem de uma delegação de estudantes a algum encontro estudantil..$^{93}$

Estas também são discussões habitualmente ausentes no cenário da formação médica no Brasil, salvo eventuais discussões nos fóruns da Saúde Coletiva: o destino dos recursos públicos. A falta de reflexão sobre o tema pode ser vista também ao analisarmos a realização de exames complementares nos hospitais de ensino. Salvo algumas restrições para a realização de exames complementares individualmente mais caros, pouca regulação existe neste tópico. Raros são os serviços que não possuem 'rotinas de internação' que não impliquem solicitação de diversos exames, independente da necessidade objetiva para cada paciente.

Esta lógica na solicitação de exames reflete também a própria falência do ensino da semiologia e da propedêutica. Não é raro ouvirmos, mesmo de médicos formados, o que ouvimos recentemente de uma médica formada há quatro anos, com quem conversávamos sobre os objetivos e métodos de pesquisa utilizados por nós neste trabalho. Ao falarmos sobre as observações nas aulas de semiologia, ouvimos de nossa interlocutora que "essas aulas de semiologia são a maior besteira que tem na faculdade. Ensinam pra gente um monte de métodos e técnicas que ninguém nunca usa na prática. Era um tal de percute

Essas conjecturas são meramente hipotéticas, não se configurando em informação baseada no conhecimento específico de uma situação, e estão apresentadas apenas para demonstração da complexidade da gestão dos recursos e da falta de transparência na tomada de decisões, muitas vezes confiada ao aparelho burocrático que cumpre normas sem uma avaliação crítica das situações. 
aqui comprime ali, quando na verdade na prática você vai direto pros exames complementares que vão te dar o diagnóstico" (feminino, 30 anos, residente de hospital público).

Essa médica estudou em uma universidade vinculada a um hospital público; se um dia ela for atuar na rede privada, terá problemas. Se tiver relação com empresas de medicina de grupo, seu trabalho será comparado ao de seus colegas, inclusive no que se refere ao número de exames que solicita por paciente. Se for trabalhar na rede privada, sem vínculo com convênios, serão os seus próprios pacientes que reclamarão pelo alto custo de um atendimento básico. ${ }^{94}$ Parece-nos que cada vez mais as faculdades formam especialistas em solicitar exames, cada vez mais incapazes de realizar um exame físico onde compreendam os sinais encontrados.

\section{Aspectos Éticos Relacionados ao Uso do Cadáver Humano no Aprendizado Profissional}

- Caso 1: "A utilização de recém-falecidos nos leitos para prática de entubação; punção de veia central etc.” (masculino, 20 anos).

- Caso 2: “É uma loucura o que acontece quando alguém morre. Todo mundo corre pra fazer alguma coisa no morto. Por que a gente não aprende em manequins?" (masculino, 23 anos).

0 cadáver de humanos é objeto de utilização para o ensino desde o primeiro período do curso, na disciplina de anatomia. Em geral, os cadáveres utilizados são de indigentes, pessoas em geral sem família ou cujo corpo não tenha sido reclamado. Há, via de regra, uma preocupação grande dos professores de anatomia em fazer preleções sobre o respeito devido pelos estudantes ao corpo que será estudado, ainda que sem vida.

O contato com o cadáver humano, tão marcante para todo estudante no início do curso, em curto espaço de tempo perde o caráter que o distingue tanto de outras experiências no curso médico. Cedo, os estudantes deixam de reconhecer naquela massa inerte, cheirando a formol, elementos que os lembrem que aquele foi um ser humano, não sendo raros os casos de brincadeiras realizadas com os cadáveres.

Depois os órgãos representativos da categoria médica revoltam-se com as propostas de controle empreendidas pelas empresas de Medicina de Grupo ou pelas ‘temidas’ de Managed Care. 
O contato com o cadáver nas aulas de medicina legal, em geral em necrotérios, representa outro impacto na vida dos jovens estudantes, já que lá os cadáveres guardam características que lembram o ser que um dia ele foi. Mas é também aqui que o seu manuseio pelos profissionais da especialidade, em nome da técnica, deixa de trazer as referências respeitosas da anatomia. Ali, em geral, estão vítimas de mortes violentas, que são manuseadas nas aulas com o único propósito de exibir as principais características de um ferimento ou de uma lesão.

0 terceiro momento em que um estudante de medicina tem contato com um cadáver humano não é um evento planejado; dá-se quando ocorre um óbito em uma enfermaria ou no serviço onde ele está estagiando. Este evento possui diferentes tipos de reação, em geral de acordo com o grau de envolvimento que ele possuía com o falecido - quanto mais envolvido ele estivesse com a assistência oferecida, maior a chance de viver a experiência como um sinal do fracasso e dos limites da atuação profissional. Quando o indivíduo já tiver 'percebido' que, para a sua futura prática profissional, ele deverá saber realizar alguns procedimentos que dificilmente terá a oportunidade de aprender sem que exponha seus pacientes a um risco demasiado de iatrogenia, ele aproveitará o momento de um óbito para praticá-los. Esses procedimentos são desde as manobras de ressuscitação simples (massagem cardíaca e ventilação mecânica com o uso de ambu), ${ }^{95}$ até a entubação endotraqueal, punção de veias profundas, dissecção de grandes vasos ou mesmo simples passagens de sondas naso e orogástrica.

A maioria desses procedimentos não será aprendida na faculdade em manequins, como seria desejável. Cada um que queira aprender terá duas opções apenas: ou o fará em um paciente vivo ou o fará em um recémfalecido. As duas opções costumam ser difíceis para os estudantes, seja pelo risco potencial na aprendizagem com um paciente vivo, seja pela percepção de violação do cadáver, que se tem ao realizar procedimentos não necessários. A faculdade, em geral, não auxilia o estudante no processo, seja pela falta de discussão sobre as situações em si, seja pela falta de oferta de condições de treinamento desses procedimentos sem que os estudantes sejam submetidos a situações de conflito desnecessárias.

Equipamento utilizado em manobras de ressuscitação que consiste em uma máscara adaptada ao nariz e boca do paciente e um balão de borracha que, quando pressionado, promove uma inspiração forçada no paciente. Também é usado logo após a colocação de tubo endotraqueal, enquanto não é acoplado o tubo a um ventilador automático. 
Ouvimos relatos, durante nossa pesquisa, sobre a realização de procedimentos não necessários em pacientes de hospitais universitários apenas para que houvesse a possibilidade de praticar algum procedimento mais complexo.

Os relatos que ouvimos estavam relacionados à punção de vasos profundos, como carótida, jugulares e subclávias. Mas os estudantes que fizeram esses relatos pediram que não fosse identificado sequer o estado em que eles estudavam, o que foi acatado por nós. A realização de procedimentos nas circunstâncias referidas não é prerrogativa brasileira nem de nossas faculdades.

Dwyer (1994: 13) descreve uma situação vivida por um estudante norteamericano que relatou ter testemunhado a realização de um parto com fórceps sem que houvesse uma indicação para tal, a despeito dos riscos relacionados com o uso desta técnica. 0 estudante conclui que a indicação foi feita apenas para que o residente pudesse treinar a realização do parto com esta técnica.

Tal fato nos possibilita introduzir uma questão que está subjacente a todo processo de aprendizagem com pacientes reais em hospitais universitários ou de ensino: quais os direitos que os pacientes têm ou teriam sendo atendidos em um hospital desse tipo.

Argumenta-se que

o fato de que nós aprendemos em pacientes significa que alguns pacientes têm uma dor ou inconvenientes ou mesmo apenas exames físicos adicionais. Eu acho que existe uma espécie de barganha: nós aprendemos Medicina nestas pessoas, que são em geral pobres, e elas têm um cuidado que de outra forma elas não teriam acesso. (Dwyer, 1994: 13)

Com pequenas variações, este é um argumento que também é ouvido em nosso país. No entanto, no Brasil, a saúde é considerada um direito de todos e uma obrigação do Estado. Não é por definição, como nos Estados Unidos, um bem acessível apenas a quem dispõe de recursos para comprá-lo.

Não desconhecemos que em nosso país há uma grande distância entre o que está escrito na Constituição e a realidade, mas isso não justifica o abuso na prática. Até porque poderíamos questionar igualmente se o atendimento usualmente oferecido nos hospitais universitários ou de ensino possui um diferencial tão significativo em relação a outros hospitais públicos. Para diversas especialidades, por exemplo, é reconhecida a superioridade de hospitais não vinculados ao aparelho de ensino formal. 
Este tema deveria ser, sem dúvida, melhor discutido nos meios acadêmicos e, especialmente, nas associações que defendem os interesses e os direitos dos pacientes, necessitando de uma reflexão sobre os limites das atividades que podem ser desenvolvidas em nome do ensino e da aprendizagem.

\section{‘Pequenas' Grandes Maldades na Prática Profissional}

- Caso 1: "Desrespeito com os pacientes. Destratações verbais e até agressões físicas, como arrancar o fio de sutura porque o paciente alcoolizado não cooperava" (masculino, 21 anos).

- Caso 2: "É comum no pronto-socorro não dar anestesia pra suturar paciente bêbado ou aplicar Benzetacil ${ }^{\circledR 96}$ só porque vai ficar doendo" (masculino, 22 anos).

Esta é uma questão que habitualmente é veementemente negada por quaisquer médicos em público: a possibilidade do uso do conhecimento profissional para a prática de pequenas 'torturas' contra seus pacientes, em atitudes que estão associadas a pequenas 'vinganças' no contexto de relações médico-pacientes mal estabelecidas. Em geral, como os dois casos citados pelos estudantes, ocorrem em pacientes alcoolizados, cuja credibilidade para denúncias posteriores é diminuída, ou em pacientes questionadores ou pitiáticos.

Ouvimos depoimentos, Brasil afora, que informavam práticas, como as aqui citadas, assim como a administração de laxantes sem conhecimento do paciente e sem indicação, aplicação de clisteres sem indicação, manutenção do paciente aguardando pelo resultado de exames indefinidamente quando os mesmos já estavam prontos e outros exemplos semelhantes, de acordo com o estado de saúde e as queixas que os pacientes tivessem.

Em nossa opinião, as razões dessas práticas podem ser encontradas na psicopatologia, como desvio de comportamento, ou no preconceito social, já que todos os relatos estavam relacionados à prática em hospitais públicos, vinculados ao Sistema Único de Saúde.

Poderíamos também reconhecer, nesta prática, um sinal de como a profissão está se afastando do ideal de serviço e, sob as influências das mudanças em sua organização e prática, aproximando-se perigosamente de um ponto em

96 Penicilina G Benzatina - é aplicada via intramuscular e é dolorosa na aplicação e durante alguns poucos dias. 
que o paciente deixará de ser reconhecido como o objetivo último de sua prática para passar a ser um meio de sobrevivência. A seguir, poderemos nos aproximar um pouco mais de manifestações inequivocamente preconceituosas.

\section{Preconceito Social}

- Caso 1: "Casos de negligência em que se inferioriza a condição de um paciente e não pede (sic) todos os exames necessários” (feminino, 18 anos).

- Caso 2: "Eu consegui um estágio em um pronto-socorro com um professor meu. $\mathrm{O}$ hospital $\mathrm{X}$ tem um grande pronto-socorro, com muito movimento. Marcamos de nos encontrar na porta do hospital. Quando íamos entrar, meu professor falou pra mim: 'aproveita pra fazer tudo que você tiver que fazer de besteira na vida pra fazer aqui, pois aqui só tem paciente do SUS, que não reclama. Se você fizer merda no seu consultório você vai tá roubada pro resto de sua vida" (feminino, 24 anos).

- Caso 3: “A gente estava discutindo um caso de uma paciente de 28 anos, com um quadro grave de insuficiência hepática com o staff. Horas tantas perguntaram ao professor se não era o caso de colocar a paciente na fila de transplante. 0 professor respondeu que não, que era pra gente prestar bem atenção ao caso: a paciente morava numa favela, era analfabeta e morava sozinha. Se ela conseguisse um fígado novo, não saberia tomar o remédio direito e, logo, logo, ferraria com o novo fígado, por isso não valia a pena colocar ela na fila. Eu fiquei assustado. Como ele pode condenar a paciente à morte, sem dar nenhuma chance a ela?" (masculino, 21 anos).

Em uma aula que fomos dar sobre ética em uma faculdade de medicina de nosso estado, um dos alunos que assistia à aula lembrou-nos de um termo que costuma ser usado em vários hospitais de pronto-socorro do município para designar seus pacientes típicos: 'Pimba'. Na verdade, é um acrônimo significando: preto, indigente, mendigo, bandido e alcoólatra. ${ }^{97}$ Nos Estados Unidos, existe um equivalente, o 'Spos' ("subhuman piece of shit") que, no caso exemplificado, tratava-se de um "paciente de quarenta anos, homem, hispânico e bandido” (Dwyer, 1994: 13).

97 Em uma versão anterior, mas ainda referida, o significado atribuído é 'pé inchado, mendigo e baleado'. 
É muito difícil entendermos tanto o 'Pimba' quanto seu congênere norte-americano, o 'Spos'. Não parece fazer sentido que profissionais dedicados a cuidar de humanos possam assumir um posicionamento tão preconceituoso, acreditando mesmo tratarem-se de pessoas de categorias inferiores e eles próprios, por conseguinte, superiores. Mas, talvez, a melhor explicação para esta 'patologia social' esteja na categoria que veremos a seguir, representando a forma como os pacientes são vistos e tratados nas escolas de medicina.

Como os professores lidam com seus pacientes e, conseqüentemente, como os estudantes, através do currículo oculto, através de mecanismos da socialização profissional, aprendem a lidar com esses mesmos pacientes. Em geral, é uma lição não verbal, mas nem por isso menos significativa. É um processo de transformação de seres humanos em Donas Maria e Seus Zé, como dizia Drauzio Varela em sua crônica.

\section{Desrespeito à Pessoa: coisificação do ser}

- Caso 1: "Eu estava participando de um round na minha enfermaria. Tinha uma paciente que toda hora tossia demais. Fazia muito barulho. Eu falei com a colega que era interna do leito, perguntando se não tinha nada que pudesse fazer com ela para diminuir a tosse. Ela me respondeu que não era pra eu me preocupar não, que ela fazia isso pra chamar a atenção, já que tava cheio de médico na enfermaria. Eu ainda perguntei se ela estava tentando chamar a atenção se não era o caso de dar essa atenção e tentar entender o que levava ela a fazer isso. Aí ela me disse que eu tinha cara de quem ia querer fazer psiquiatria, mas que eu precisava entender que não dá pra ficar dando papo pra paciente o tempo todo não, que senão você não faz mais nada" (masculino, 22 anos).

- Caso 2: "Eu estava acompanhando um médico que estava atendendo uma criança, com a mãe, que tinha caído da rede e batido com a cabeça no chão. Mal a mãe acabou de falar, o médico a chamou de irresponsável, que tinha que estar de olho o tempo todo na criança. A mãe começou a chorar morrendo de vergonha" (feminino, 19 anos).

- Caso 3: "Acho um absurdo que professores, na hora da visita, fiquem falando da situação do paciente sem nenhuma consideração com o paciente!" (feminino, 24 anos). 
- Caso 4: "Diariamente nas enfermarias, durante as aulas de propedêutica, observamos manipulação excessiva de pacientes. Alguns são auscultados por três estudantes ao mesmo tempo, outras vezes, estes mesmos estudantes e até mesmo os professores discutem casos na frente do paciente utilizando-se de termos técnicos, o que deixa os pacientes receosos quanto ao seu diagnóstico e prognóstico. Certa vez, um estudante estava auscultando um paciente e falou: "- Gente! Venham auscultar aqui... ele tem um ritmo de galope!' Resultado: o paciente ficou tão assustado que perguntou se ia morrer! Os professores deveriam se preocupar mais com os reflexos de tais atitudes" (feminino, 20 anos).

- Caso 5: "A questão do relacionamento médico-paciente. Durante ambulatório de pneumologia, o paciente desconhecia que estava com câncer e a devida ferocidade do tumor. Ele só sabia que estava sendo tratado como pneumonia" (masculino, 22 anos).

- Caso 6: "Na minha faculdade o serviço de ginecologia, em particular, é o campeão na falta de ética para com as pacientes, que são orientadas a não perturbar e não gritar nos seus maiores momentos de dor" (feminino, 25 anos).

- Caso 7: "Aulas práticas com o uso do paciente como mera cobaia" (masculino, 23 anos).

- Caso 8: "0 paciente dependia de oxigênio, mas não tinha condições para se manter com oxigênio em casa e mesmo assim foi dada alta, sem ser discutido como seria o tratamento do paciente em casa" (masculino, 22 anos).

- Caso 9: "Foram várias, mas aqui vai um exemplo: na aula prática de psiquiatria, onde um professor entrevista um dos pacientes da internação psiquiátrica, a professora questionava o paciente e dizia para os alunos notarem o quanto ele estava 'louco', 'sem nexo'. Ficamos todos com vergonha, pois ela literalmente ridicularizou o paciente" (feminino, 23 anos).

- Caso 10: "0 monitor de semiologia estava fazendo uma revisão com o meu grupo em um paciente internado. Só que ele deixou o paciente completamente nu por mais de duas horas, sem deixar nem o lençol cobrindo ele" (feminino, 21 anos). 
- Caso 11: "Professores na beira do leito falando da situação do paciente de forma inadequada (absurdo!!!)” (feminino, 24 anos).

- Caso 12: "Situação em que os estudantes (muitos) estavam estudando semiologia frente a (sic) um paciente grave” (masculino, 26 anos).

- Caso 13: "Modo de tratar e expor o paciente" (feminino, 21 anos).

0 número de casos apresentados nesta categoria é superior ao das demais e não é por uma simples opção nossa. Outros casos, incluídos nas categorias anteriores, podiam, como os leitores perceberam, estar facilmente incluídas aqui. Não o fizemos para dar um destaque a algumas características peculiares que eles tinham. Mas o número dos relatos aqui incluídos é uma expressão concreta de como esse problema chama a atenção dos estudantes e como é difícil para eles lidarem com estas situações.

0 que transparece da leitura desses casos é uma sensação de que cada um dos estudantes viveu uma situação dramática, na qual o que, para eles, era importante em uma relação entre médicos e pacientes não era considerado: 0 respeito à pessoa. Não se trata apenas do desrespeito a um valor ou a um direito, mas da desconsideração daquele indivíduo como pessoa.

Konner (1988), em seus relatos sobre sua própria experiência na faculdade de medicina, relata diversos episódios que têm grande identidade com os relatos aqui transcritos. Em um desses episódios, ele narra o início de seu estágio no pronto-socorro quando houve uma aula na sala de pequenas cirurgias.

Durante a aula, repetidas vezes, um paciente com um ferimento na cabeça buscava espiar para o interior da sala. Konner estranhava que ninguém desse sinal de que estivesse reparando a presença do paciente até que, após meia hora, ele decidiu falar para o professor que havia um paciente na porta. Seu professor respondeu-lhe, dedo em riste: "eu vou ter que lhe pedir... se você for me interromper mais uma vez eu vou ter que lhe pedir que saia da sala". Konner ficou quieto e, ao final da aula, constatou que o paciente, vítima de um acidente de carro, havia saído do hospital. A papeleta foi preenchida pelo residente "acusava-o de ter saído contra a orientação médica. Que orientação médica? Ele não viu um médico em momento algum!” (Konner, 1988: 56-57).

Este não é um problema das escolas médicas brasileiras e nem tampouco um problema recente. A leitura desses casos nos trouxe à lembrança a exposição feita por Jean Robinson, representante leiga no General Medical Council, 
na Inglaterra, em uma Medical Ethics Education Conference, intitulada "Are we teaching students that patient don't matter?". Robinson observava que os estudantes de medicina estavam percebendo que "seu treinamento profissional estava levando-os a abandonar as atitudes de cuidado que os haviam atraído para a Medicina" (1985: 19), uma vez que os direitos dos médicos eram mais valorizados, tanto nas aulas quanto no ensino indireto, do que aqueles dos pacientes.

Da leitura desses casos e do convívio com os estudantes ao longo dos anos em que temos nos dedicado a estudar o processo de formação, percebemos este processo como alienante e desumanizante. Junto ao ensinamento de se adotar um distanciamento emocional do paciente, sem dúvida indispensável para uma análise e abordagem crítica de cada um com quem o estudante se envolve em um processo terapêutico, está um aprendizado prático de que este distanciamento se dá pela negação da condição de sujeito ao outro; pela negação de sua capacidade de pensar e de decidir sobre o seu destino; pela fragmentação do indivíduo em órgãos e sistemas isolados; pela descontextualização da ação terapêutica.

É claro também que nem todos que entram em uma escola médica a terminam com a mesma prática ou com a mesma visão do mundo e do paciente, mas é inegável que o conjunto de experiências ao qual a maioria dos estudantes está sendo exposta no quotidiano de nossas faculdades de medicina e, especialmente, a falta de uma orientação e ação concreta da faculdade através de seus professores e médicos reafirmam esta lição indireta.

A força do processo de socialização, entendido como o processo por meio do qual os valores, atitudes, linguagem, específicos de uma profissão são informados aos estudantes desejosos de fazer parte daquela corporação profissional é inegável, mas também é insuficiente para explicar esta situação tão complexa. Não podemos optar pela solução mais fácil e atribuí-la apenas a uma imitação do mau exemplo, à compreensão deteriorada dos objetivos da medicina e de seu processo de trabalho. São inúmeras as hipóteses que podem ser levantadas para explicar o processo de socialização, sem que provavelmente se encontre a resposta em uma única linha de raciocínio ou em um único aspecto do processo de formação. As explicações seguindo a linha teórica da socialização são um bom começo, mas insuficientes, embora ajudem no esclarecimento das diferenças individuais observadas, atribuindo-as às discrepâncias entre os conteúdos desta com os da socialização primária. 
Ainda no campo teórico da socialização, é interessante lembrar a comparação feita por Morin (1996: 50) entre o fenômeno do imprinting, descrito pela etologia ("para o passarinho, o primeiro ser que passa perto do ovo de onde ele saiu é a sua mãe"), e os efeitos da ação do aparelho formador ("na escola e na universidade, sofremos 'imprinting' terriveis, sem que possamos, então abandonálos. Depois disso, a invenção acontecerá entre aqueles que sofreram menos o ‘imprinting' e que serão considerados como dissidentes ou discordantes”). A socialização profissional, incluindo-se as lições do currículo oculto, serão parte desse imprinting cultural, ao qual podemos estar mais ou menos suscetíveis. Costumamos dizer que a socialização profissional é um processo extremamente poderoso e que aqueles que resistem à dessensibilização que o perpassa acabam se tornando pediatras ou sanitaristas, estes, sem dúvida, os que representam os maiores desviantes entre os médicos, o que não significa que outros especialistas também não possam sofrer menos com o imprinting da escola médica.

Uma outra hipótese explicativa para o fenômeno em questão pode ser construída se levarmos em consideração o processo de divisão do corpo humano em órgãos e sistemas para fins de ensino; aliás, explicação recorrentemente ouvida nos fóruns em que se discute a educação médica em nosso país, embora raramente ela seja formulada de forma consistente.

A fragmentação teórica do corpo humano em órgãos e sistemas é um método que permite o conhecimento deste organismo através de suas partes e pode ser visto como um dos resultantes da Reforma Flexner. Mas é complicado atribuir-se pura e simplesmente a este método a responsabilidade pela não reconstrução desse organismo e a incorporação de sua dimensão de pessoa, apenas porque o método de ensino recorta-o pedagógica e fisiologicamente. Esta hipótese pode até ser verdadeira, mas ainda não foi convenientemente justificada teoricamente para ser aceita, embora possamos, partindo deste mesmo ponto, seguir por outra linha de raciocínio.

Consideremos inicialmente a distinção que Fidalgo nos recorda entre técnica e saber:

A caracterização de ciência feita por Aristóteles no Primeiro Livro da Metafísica assenta na distinção entre a técnica e o saber. A técnica é o conhecimento do profissional, isto é, o saber fazer baseado na experiência. É um conhecimento dos fatos, do que acontece e como acontece, mas não um saber das razões e das causas do que acontece. Este é o verdadeiro saber ou o saber científico. (Fidalgo, 2000) 
Fundamentados nesta distinção, poderíamos dizer que Flexner, ao dar ênfase ao ensino das chamadas disciplinas básicas no curso médico (o conhecimento biológico), entendia claramente tratar-se este conhecimento do fundamento científico da medicina. Entretanto, coerente com a proposta de uma reforma educacional voltada para uma formação profissional, estimulou o vínculo do ensino com a prática profissional e o ensino das técnicas de acordo com a realidade das especialidades então existentes e que só se multiplicaram.

É claro que o conhecimento especializado sempre foi socialmente mais valorizado, uma vez que o entendimento da sociedade é o de que quanto mais o saber foi especializado mais adequado será para resolver problemas específicos. Daí as próprias faculdades de medicina, seus professores e alunos darem cada vez mais ênfase ao ensino e aprendizado especializado.

Os estudantes desejam aprender o que for eminentemente prático, o que os auxiliará a resolver os problemas que eles esperam enfrentar após a graduação. Nesse sentido, todo conhecimento que não tem uma aplicabilidade prática evidente tende a ser menosprezado e não apenas pelo corpo discente.

Tome-se como exemplo a importância dos departamentos de medicina preventiva, tanto do ponto de vista pedagógico quanto político e administrativo, para as faculdades de medicina, e ver-se-á claramente como a universidade passa a lidar com o conhecimento não comprometido diretamente com a solução de um problema de saúde específico, mas com o das comunidades. ${ }^{98}$ Tomese como exemplo os departamentos do ciclo básico, em que muitos dos docentes nem médicos são, e veremos a importância dada a estas disciplinas pela faculdade. São todos marginais no meio universitário.

Com a ênfase voltada para o ensino técnico, no qual a atenção da ação de trabalho está fixada em um problema delimitado por um órgão ou sistema, existe uma maior dificuldade para que os médicos deixem de focalizá-lo ao utilizar a técnica. Verifica-se então o que chamamos inicialmente de 'coisificação' do ser, mas que poderíamos, seguindo a tradição marxiana, chamar de objetificação do ser humano, ou seja, a transformação do ser humano em um mero objeto de trabalho, objeto de aplicação de uma técnica.

98 Certamente não é mero acaso as disciplinas de saúde coletiva serem conhecidas pelo acrônimo formado por suas iniciais: SA CO. É bem verdade que mesmo entre os docentes da saúde coletiva também existem, e não em pequeno número, aqueles que consideram um ‘SA CO' dar aulas na graduação, mas este é um comportamento comum entre docentes universitários e não exclusivo da saúde coletiva. 
Tal fato explicaria a compreensão limitada do trabalho médico, compartilhada por muitos profissionais e estudantes e que foi expressa no caso 8, no qual o paciente, dependente de oxigênio, recebe alta sem que seja discutido ou pensado em como conseguirá viver em casa com tal limitação. É um exemplo claro de como, muitas vezes, o atendimento médico prestado limita-se ao momento em que o paciente está diretamente sob os cuidados do profissional, sem que ele logre incluir em suas análises o indivíduo como um ser que, saindo de lá, precisaria manter-se vivo.

Outro exemplo possível para este tipo de situação foi um episódio vivido por nós há alguns anos, quando atendíamos uma criança com um quadro de tuberculose avançada e, ao instruirmos a mãe sobre a necessidade de ela também fazer exames para a detecção de tuberculose, fomos informados de que ela e seu marido já estavam em tratamento de tuberculose há alguns meses. Perguntamos a ela se ninguém a havia alertado sobre a necessidade de levar seu filho para uma consulta e sua resposta foi negativa, embora ela houvesse alertado ter filhos em casa.

Poderíamos igualmente considerar a 'coisificação' do seu paciente, observado entre os estudantes, como parte de um fenômeno mais geral, presente na sociedade na modernidade e que pode ser referido genericamente como uma ênfase no individualismo.

Diversos autores, cada um com sua abordagem orientada teoricamente de forma distinta das demais, assinalaram este fenômeno como característico da modernidade ou, mais especificamente, fruto do desenvolvimento do capitalismo, como por exemplo: Sennet (1988), em seu O Declínio do Homem Público; Christopher Lasch (1986), em seu O Mínimo Eu: sobrevivência psíquica em tempos de crise; Louis Dumont (2000), em O Individualismo: uma perspectiva antropológica; Christophe Déjours (1999), em A Banalização da Injustiça Social, e, para citar alguns brasileiros, Luís Belluzzo e Jurandir Freire Costa, em diversos artigos. Talvez todos nós estejamos apenas vivendo o momento que Weber anteviu ao final de seu A Ética Protestante e o Espírito do Capitalismo:

Ninguém sabe ainda a quem caberá viver nessa prisão, ou se, no fim desse tremendo desenvolvimento, não surgirão profetas inteiramente novos, ou um vigoroso renascimento de velhos pensamentos e idéias, ou ainda se nenhuma das duas - a eventualidade de uma petrificação mecanizada caracterizada por esta convulsiva espécie de auto-justificação. Nesse caso, os 'últimos homens' 
desse desenvolvimento cultural poderiam ser designados como 'especialistas sem espírito', sensualistas sem coração, nulidades que imaginam ter atingido um nível de civilização nunca antes alcançado”. (1987: 131)

Nossas conclusões em relação à objetificação do ser humano podem ser inferidas igualmente a partir de outros trabalhos. Por exemplo, alguns pesquisadores, associados à corrente teórica do desenvolvimento moral fundada por Piaget e Kohlberg, direta ou indiretamente, identificaram o mesmo fenômeno que nós: Lind (2000) e Self et al. (1989, 1994, 1996), por exemplo.

Devemos recordar que enquanto Self trabalha com o instrumento desenvolvido por James Rest, o Defining lssues Test (DIT), Lind desenvolveu seu próprio instrumento, o Moral Judgement Test (MJT). A diferença entre os dois testes é bastante significativa, uma vez que aquele se limita a identificar o estágio de desenvolvimento moral do ponto de vista cognitivo, entendendo-o como a capacidade de raciocinar moralmente e apresentar soluções morais para dilemas pré-formulados e este pretende ser capaz de avaliar tanto a capacidade de raciocínio moral quanto o da ação moral. 0 MJT tem também como característica não se satisfazer com a apresentação apenas da argumentação sobre a decisão moral tomada pelo entrevistado, mas espera também que cada um seja capaz de apresentar antíteses aos próprios argumentos, configurando, assim, o pleno desenvolvimento cognitivo.

Self et al., na maioria de seus trabalhos, por exemplo, identificam um discreto crescimento do desenvolvimento moral dos alunos de medicina, ao comparar os testes realizados antes e depois dos alunos terem aula na disciplina de ética e mesmo entre o início e o fim do curso médico. São resultados discretos, mas que ele qualifica como evidência de que há uma contribuição positiva das disciplinas nas turmas analisadas.

Lind, por sua vez, analisou os dados obtidos por Self em seus estudos com estudantes de medicina e de outros cursos e refutou suas conclusões. Para ele, a comparação dos resultados dessas pesquisas demostram que os alunos de outros cursos têm melhores resultados nos testes de desenvolvimento moral.

Lind realizou um estudo longitudinal de seis anos de duração com 746 estudantes de medicina e dois estudos seccionais cruzados de estudantes de medicina com outros estudantes $(n=4966)$. Suas conclusões foram de que, na média, estudantes de medicina mostram uma regressão na sua competência de 
julgamento moral enquanto outros estudantes universitários mostram um aumento considerável e esta regressão nas competências de julgamento moral está relacionada a deficiências no ambiente de ensino das escolas médicas (Lind, 2000).

Como já fizemos referência no capítulo anterior, discordamos absolutamente da possibilidade de ocorrer uma regressão nas capacidades cognitivas, salvo nas reconhecidas situações clínicas, como a doença de Alzheimer, por exemplo. As diferenças que lind observa devem ser compreendidas como os resultados obtidos na realização de um teste, que, no caso específico, demonstra não a capacidade cognitiva em compreender e elaborar argumentos que sejam compatíveis com os diferentes níveis de desenvolvimento moral, mas uma expressão de como o processo de formação profissional em medicina leva os indivíduos a desconsiderarem o outro, no caso, os pacientes.

A capacidade cognitiva, teórica, permanece, mas a forma como esses indivíduos são levados a pensar as situações envolvendo decisões de ordem moral muda, e é isto que os testes reconhecem quando apontam para a suposta regressão, já que a escala de desenvolvimento moral elaborada por Kohlberg tende a considerar como estágios de menor desenvolvimento aqueles que expressam um maior individualismo.

Nesse sentido, os estudos de lind chegam à mesma conclusão que o nosso, embora enfoquem, em suas conclusões, apenas o aspecto cognitivo, admitindo, assim, que alguém possa perder capacidades cognitivas já adquiridas. Suas conclusões, de fato, deveriam enfatizar mais o aspecto da mudança de atitudes (que seu teste também inclui na mensuração) do que o aspecto cognitivo propriamente dito. Resta, portanto, a já clássica pergunta: o que determina o comportamento moral, uma vez que a capacidade cognitiva é necessária, mas não suficiente para determiná-lo?

Um ensaio de Young (1997), vencedor de um concurso promovido pelo Canadian Medical Association Journal em 1996, ajuda nossa reflexão sobre a complexidade da relação entre o pensar e o agir. A autora discute o processo de seleção de médicos para os programas de residência médica, no qual os interessados precisam escrever cartas justificando as razões pelas quais se consideram os melhores candidatos às vagas, como uma abordagem sobre a honestidade como valor na prática profissional.

Segundo a autora, como cada recém-graduado candidata-se normalmente a mais de uma residência médica em mais de uma especialidade, o 
sistema de seleção os induz a mentir em suas cartas, de forma a obter o fim desejado. Para a autora, esta e outras práticas estabelecidas durante a graduação estimulam o comportamento desonesto dos estudantes, incluída aí a 'cola'; a partir disso, a autora questiona se tal treinamento para a desonestidade durante a graduação não levaria os estudantes a se comportarem de forma semelhante depois de formados sempre que perceberem que a mentira ou a desonestidade poderá assegurar-lhes benefícios pessoais. Dessa forma, pouco adiantariam aulas e discussões sobre ética se, na prática, o próprio sistema os leva a uma prática desonesta.

Seguindo sua linha de análise, poderíamos inferir que o comportamento de um indivíduo estaria diretamente relacionado aos valores que o grupo no qual ele está inserido possui, minimizando, desse modo, a relevância dos valores individuais nas decisões a serem tomadas. Ressaltamos que este comportamento, aparentemente fundamentado por reflexões morais do tipo 'convencionais', de Kohlberg, seria muito mais reforçado no caso dos estudantes de medicina que lutam para se sentirem parte de uma corporação profissional, cujo poder e tradição extrapola seus próprios limites. Assim sendo, haverá sentido e razões para se crer na eficácia de uma educação moral? Ou, retomando a forma como habitualmente esta pergunta é feita: ética pode ser ensinada? Como esta questão tem sido tratada por faculdades de medicina em outros países e que métodos têm sido propostos para se atingir tal objetivo? 


\section{As Possibilidades e os Limites da Educação Moral}

Entendemos que a primeira parte das perguntas foi amplamente respondida ao longo deste livro. Não só é possível interferir no processo de desenvolvimento moral, como esta interferência produz resultados mensuráveis. ${ }^{99}$ Se a pergunta é habitualmente mal respondida entre médicos, especial, mas não exclusivamente, em países como o Brasil, é apenas pelo (mal) hábito dos docentes médicos e dirigentes corporativos de restringirem suas leituras ao que é produzido diretamente por integrantes do campo médico ou, mais recentemente, da saúde. Mas a resposta não é oriunda desse campo do saber, e a multi, inter e transdisciplinaridade ainda está, na maior parte das vezes, restrita aos que se incluem no campo da saúde coletiva. Há que se buscar na pedagogia, na psicologia, na sociologia e na filosofia as perguntas necessárias e as respostas possíveis. ${ }^{100}$

Restam por discutir quais as melhores estratégias educativas para favorecer uma socialização profissional que estimule a autonomia dos estudantes, o respeito à diversidade e pluralidade cultural e moral, e esta não é uma questão simples de ser equacionada.

Se, como vimos no capítulo 3, Durkheim, Kant e Piaget divergiam sobre a melhor forma de se praticar a educação moral, ainda hoje a questão deve ser considerada ainda aberto. No Brasil, os atuais parâmetros curriculares nacionais (Brasil, 1997) preconizam, já para o ensino de $1^{\circ}$ grau, a inclusão de temas transversais de ética para os estudantes. Os educadores de nosso país, talvez ainda traumatizados pela experiência do período autoritário com as disciplinas

\footnotetext{
99 Ver todos os trabalhos de Donnie Self $(1989,1992,1993,1994,1996,1998)$ nas referências bibliográficas e os de Judith Andre (1992) e Holm et al.( 1995).

100 Ainda que autores como Hansen (1995) defendam a idéia de que moral não é ensinada, mas 'adquirida' (caught, no original), a essência de sua crítica não está na impossibilidade de se 'ensinar ética', mas na concepção ‘bancária' da educação. Logo, ele está dirigindo sua crítica ao ponto errado, possivelmente pela sua própria concepção de educação.
} 
"educação moral e cívica" e "estudos de problemas brasileiros”, optaram por não preconizar a criação de uma disciplina específica, mas a abordagem de seus temas transversalmente, isto é, em todas as disciplinas de forma integrada.

Não há dúvida de que a proposta de ensino transversal é interessante, mas convém questionarmos o possível alcance dela em nosso meio, ${ }^{101}$ no qual a ética é majoritariamente entendida apenas como a aplicação de um código, especialmente em seu aspecto de defesa corporativa. Será possível imaginarmos que, a curto ou médio prazo, possamos ter os mesmos professores que são citados pelos alunos entrevistados por nós, discutindo convenientemente ética? Diríamos até que o cerne da questão não está apenas nas características do professor, mas na falta de reflexão sobre os reais aspectos éticos que envolvem as relações de assistência à saúde. Não é raro, mesmo entre pessoas muito esclarecidas e com altos níveis de educação acadêmica, o desconhecimento e a desconsideração sobre os aspectos éticos de sua prática, acreditando piamente que basta sua boa vontade e suas boas intenções para assegurar o caráter ético de suas ações, de suas pesquisas.

Entendemos que o ensino transversal da ética deve ser um objetivo para o sistema educacional, nele incluído, obviamente, o ensino médico, mas não é uma proposta viável senão em longo prazo, desde que outras condições tenham sido previamente conquistadas. É claro que não defendemos a idéia de que não se deve fazer nada, e é no sentido de entendermos como outras instituições e países vêm equacionando esta questão que promovemos uma ampla revisão bibliográfica sobre o tema, que sintetizamos a seguir.

Shelton (1999) e Kopelman (1999) abordam dois aspectos dessa questão, e o fazem com duas perguntas básicas, respectivamente: "Pode a virtude ser ensinada?" e "Valores e virtudes: como eles podem ser ensinados?".

Shelton alerta-nos para a necessidade de que se tenha um ambiente em que a ética e a prática ética sejam uma realidade, lembrando-nos do importante papel desempenhado pelo currículo oculto na formação dos estudantes e da importância de não ocorrerem contradições entre o que é ensinado/discutido nas aulas e o que os alunos observam no quotidiano.

Kopelman, por sua vez, compara os argumentos daqueles que defendem que os objetivos da educação moral devem ser o de tornar os estudantes mais

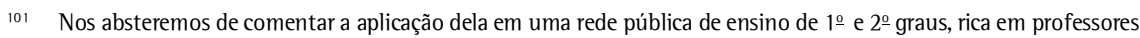
malformados e mal pagos, que têm na vocação ou na falta de opções o motivador de seu trabalho. 
'humanos' e virtuosos e daqueles que defendem a idéia de que a educação em ética deve ser mais instrumental, tornando-os mais capazes de resolver os problemas éticos com os quais provavelmente se confrontarão quando estiverem na prática profissional, para concluir que a discussão é inócua e que os dois aspectos não são excludentes. Ao final, alerta que

\begin{abstract}
talvez a mais poderosa maneira como os estudantes são ensinados sobre valores e virtudes profissionais seja o exemplo. As ações dos clínicos ensina aos estudantes o que a sua profissão espera deles. Mostrando pouca tolerância para comentários prejudiciais e 'piadas' preconceituosas; expressando preocupação com os estudantes, pacientes e familiares; levando o tempo necessário para obter um consentimento livre e esclarecido significativo; mantendo-se atualizado com a literatura e mostrando respeito e empatia, ele moldará o que os estudantes serão e farão. (Kopelman, 1999: 1310)
\end{abstract}

Kopelman também valoriza o currículo oculto, mas introduz algumas questões ignoradas por seus colegas: se iremos ou devemos ensinar virtudes aos estudantes, que virtudes serão essas? Ao que podemos acrescentar: quem determinaria as virtudes que devem ser ensinadas? Quais seriam as 'virtudes básicas' aceitas consensualmente como as mais importantes em uma sociedade democrática e plural? Como estabelecer um padrão de virtudes entre os docentes para que possam demonstrá-las pelo seu exemplo? Seria o caso de selecionar os docentes também por suas virtudes? Que tipo de teste poderia ser feito para verificar as virtudes defendidas efetivamente por alguém? Não. Não nos parece ser este o melhor caminho para pensarmos a educação em uma sociedade democrática e pluralista.

Concordamos com Puig (1998) quando ele afirma que, embora habitualmente a educação moral seja associada a formas educativas tradicionais como uma imposição heterônoma de valores e normas, devemos pensá-la associada ao objetivo de "ajudar a analisar criticamente a realidade quotidiana e as normas sociomorais vigentes, de modo que contribua para idealizar formas mais justas e adequadas de convivência” (Puig, 1998: 16).

Desse modo, a educação moral deve ser vista como uma forma de favorecer o desenvolvimento moral do indivíduo, ou seja, o desenvolvimento de sua capacidade de raciocinar e julgar questões morais. Precisamos ajudar o indivíduo a ser capaz de conviver em uma sociedade democrática e pluralista, preocupado com a busca por estabelecer e favorecer relações mais justas na sociedade, mas também a ser capaz de raciocinar de forma autônoma. 
Com a definição do objetivo da educação moral como o favorecimento ao desenvolvimento da capacidade do indivíduo e do grupo de lidarem de forma respeitosa com a diversidade de opiniões e, ao mesmo tempo, exprimirem suas convicções e avaliações sobre os aspectos morais envolvidos, não será um papel do professor ${ }^{102}$ ou da escola a definição de que valores deverão ser ensinados, mas o de estabelecer os métodos, técnicas e conteúdos mais adequados para tal.

Nesse sentido, entendemos que os conteúdos não devem se limitar àqueles estritamente relacionados às situações que se acredita que os estudantes venham a se confrontar depois de formados, mas incluir desde a filosofia da moral e da ciência, como uma base consistente para a reflexão moral autônoma, mas condizente com os próprios objetivos do curso, até as situações práticas concretas que os estudantes vivenciam durante a graduação, sobre as quais apresentamos um panorama neste trabalho, e aquelas que definiríamos como clássicas na prática médica.

Santos (1995: 190-200), refletindo sobre as funções da universidade, afirma que um dos seus dilemas institucionais contemporâneos é a contradição entre o ensino da alta cultura e da cultura das massas, que estaria diretamente relacionado à crise que ela vive atualmente.

Em sua visão, ao ser confrontada com a necessidade de não apenas formar a elite dirigente da sociedade, mas de incorporar em seus ensinamentos a lógica da produção, distribuição e consumo, a universidade foi incapaz de redefinir seus objetos de trabalho e incorporou a dicotomia em seu interior, sem resolvê-la.

Todavia, nós entendemos que a universidade respondeu a esta crise buscando acentuar uma vertente mais pragmática, capaz de fornecer instrumentos específicos para a inserção do aluno no mercado de trabalho e deixando de prepará-lo para tornar-se capaz de buscar novas respostas para novos desafios, e é desta maneira que ela tradicionalmente lidou com a questão do ensino da ética - oferecendo aos alunos o Código de Ética como conteúdo enquanto ele foi suficiente, e, hoje, buscando prepará-lo com as discussões dos futuros casos com os quais ele possivelmente se confrontará. Contrários a esta postura, situam-se igualmente os que, como Carson (1994), defendem que o ensino da ética seja inserido em um amplo contexto do ensino de humanidades médicas.

102 Ao contrário do que defendem Ales et al. (1992). 
As humanidades médicas, tal como Carson (1994) preconiza e foram implementadas no Institute for Medical Humanities da University of Texas Medical Branch, em Galveston (UTMB), incluem desde a literatura clássica e moderna até psicologia, direito, filosofia e ética. ${ }^{103}$ Assim, busca-se uma retomada do ensino da alta cultura com o claro objetivo de tornar os alunos melhor preparados para o mercado de trabalho.

0 que parece já representar um consenso entre os autores dedicados especificamente aos métodos de ensino da ética é a defesa da utilização de pequenos grupos para as aulas e discussões, por exemplo, Calman \& Downie (1987); Parker (1995); Tysinger et al. (1997); Self et al. (1998). Esta forma de organização das turmas é coerente com a teoria do desenvolvimento moral de Piaget/Kohlberg, na medida em que possibilita aos estudantes uma participação ativa nas aulas e uma troca de opiniões mais intensa entre os pares, o que, de acordo com esta teoria, é um dos elementos catalisadores do processo, bem como encontram nos modelos de ensino baseados na problematização ou na Aprendizagem Baseada em Problemas seu principal estuário.

Preocupados, como Myser, Kerrudge \& Mitchell (1995) e Silverman (1996), em diminuir o lapso entre conhecimento e prática, entre competência moral e prática ética, encontramos em Faulkner \& McCurdy (2000) a perspectiva que nos parece indispensável de ser também incorporada no contexto desta discussão, particularmente em nosso país: a da responsabilidade social.

Em nosso país, a tradição da ação estudantil é a da ação e agitação política, sem dúvida imprescindíveis para a sociedade no passado como hoje. Mas a incorporação das ações de extensão universitária aos objetivos da universidade (Santos, 1995) abriu um leque de oportunidades educacionais que nos parece ainda ser muito pouco valorizado e considerado, por docentes e estudantes, a despeito das atividades que, sem dúvida, vêm sendo desenvolvidas em diversas faculdades de medicina em caráter eletivo.

0 Pulse, seção estudantil do Journal of American Medical Association, publicou, em 1996, um conjunto de artigos sobre o ativismo estudantil, ${ }^{104}$ entendido não como a ação política ideológica com a qual estamos acostumados pela experiência brasileira, mas relacionada à secularização da ética protestante

103 Coles (1998) defende a mesma perspectiva.

104 Sei que muitos em nosso país, provavelmente os mais jovens e/ou engajados na luta política e ideológica, manifestarão seu desconforto e mesmo desprezo com a utilização de exemplos, neste campo, oriundos dos Estados Unidos, mas discordamos da não utilização deles apenas por serem desprovidos de um sentido político. Também não temos conhecimento de publicações semelhantes originárias dos estudantes brasileiros ou latino-americanos. 
descrita por Weber (1987). Neste encarte, Bambas (1996) apresenta os resultados de um survey realizado pela American Medical Student Association sobre o tema, que enfatiza três campos de atuação: 'Saúde pela Paz', 'Saúde Internacional' e 'Ação Legislativa'. As duas primeiras incluem ações concretas de solidariedade nacional e internacional, com a participação em atividades da Anistia Internacional ou de apoio às comunidades minoritárias naquele país. Está claro, entretanto, que suas ações também são limitadas a um pequeno número de estudantes. Assim, ações de extensão como as desenvolvidas pela University of Texas Medical Branch (UTMB) e descritas por Bambas \& Smith (2000), inseridas no contexto do ensino de ética, são estratégias que podem inspirar ações semelhantes em nosso país.

Finalmente, devemos assinalar que a própria World Medical Association, representante maior da corporação médica, publicou, em outubro de 1999, uma Resolução onde "recomenda às Escolas Médicas distribuídas em todo o mundo que o ensino da Ética Médica e dos Direitos Humanos seja incluído como um curso obrigatório em seus currículos" (WMA, 1999), por considerar que tanto a ética médica como os direitos humanos fazem parte do trabalho e da cultura da profissão médica. A recomendação em relação ao ensino da ética não traz surpresa, mas a inclusão do tema 'direitos humanos' não apenas se insere perfeitamente na proposta de ensino da ética no contexto das humanidades médicas, como ressalta a importância de atuarmos de forma a incentivar o ativismo estudantil, auxiliando-o e incentivando-o com os instrumentos disponíveis. 


\section{Referências Bibliográficas}

ALES, K. L. et al. Using faculty consensus to develop and implement a medical ethics course. Academic Medicine, 67(6): 406-408, 1992.

ALMEIDA, M. J. Educação Médica e Saúde: possibilidades de mudança. Londrina: Editora UEL, 1999.

AMARGO, M. C. Z. A. 0 ensino da ética médica e o horizonte da bioética. Revista de Bioética, 9, 1996. Disponivel em:<http://www.cfm.org>. Acesso em: out.1998.

ANDRADE, J. Marco conceptual de la educacion medica en la America Latina. Serie Desarrollo de Recursos Humanos, 28. Washington: Opas, 1979.

ANDRE, J. Learning to see: moral growth during medical training. Journal of Medical Ethics, 18: 148-152, 1992.

ARAÚJO, A. R. A Assistência Médico-Hospitalar no Rio de Janeiro no Século XIX. Rio de Janeiro: MEC, 1982.

ATALLAH, A. N. \& CASTRO, A. A. Medicina Baseada em Evidências: o elo entre a boa ciência e a boa prática clínica. 2001. Disponível em: <http:// www.epm.br/cochrane/ebm.html>. Acesso em: set. 2000.

BALDWIN. D. C. et al. Moral reasoning and malpractice: a pilot study of orthopedic surgeons. The American Journal of Orthopedics, 481-484, jul., 1996.

BAMBAS, A. Getting started: a survey of medical student activism. Journal of the American Medical Association, 276(17): 1436-1437, 1996.

BAMBAS, A. \& SMITH, K. The service experience: an alternative to the classroombased model for moral development of health professionals. Revista Brasileira de Educação Médica, 24(1): 36-46, 2000. 
BASILE, M. A. Uma experiência nacional: Cinaem. In: MARCONDES, E. \& GONÇALVES, E. L. (Orgs.) Educação Médica. São Paulo: Sarvier, 1999.

BECKER, H. S. \& GEER, B. Medical education. In: FREEMAN, H. E. (Ed.) Handbook of Medical Sociology. New Jersey: Englewood Cliffs/Prentice Hall, 1963.

BECKER, H. S. et al. Boys in White: student culture in medical school. 5.ed. Chicago: University of Chicago Press, 1997. (1.ed., 1961)

BELLUZZO, L. G. M. A Política da globalização: os efeitos têm sido a decadência de regiões, mais desemprego e o aumento da desigualdade. Folha de S. Paulo, São Paulo, 10 set. 1995. Disponível em: <http://www.eco.unicamp.br/artigos/belluzzo/artigo11.htm>. Acesso em:11 mar. 2003.

BELLUZZO, L. G. M. Assim caminha a humanidade. Folha de S. Paulo, São Paulo, 22 mar. 1998. Disponível em: <http://www.eco.unicamp.br/artigos/ belluzzo/artigo54.htm>. Acesso em: 11 mar. 2003.

BERGER, P. L. \& LUCKMANN, T. A Construção Social da Realidade: tratado de sociologia do conhecimento. 8.ed. Petrópolis: Vozes, 1990.

BlAgGiO, A. M. B. Psicologia do Desenvolvimento. 13.ed. Petrópolis: Vozes, 1998a.

BIAGGIO, A. M. B. Introdução à teoria de julgamento moral. In: NUNES, M. L. T. (Org.) Moral \& TV. Porto Alegre: Evangraf, 1998b.

BICKEL, J. Medical students' professional ethics: defining the problems and development recources. Academic Medicine, 66: 726-729, 1991.

BL00M, S. W. Structure and ideology in medical education: an analysis of resistance to change. Journal of Health and Social Behavior, 29: 294-306, dec., 1988.

BOURDIEU, P. Razões Práticas: sobre a teoria da ação. Campinas: Papirus, 1996.

BRASIL. Lei no 6494, 7 dez.1977. Brasília, 1977.

BRASIL. Secretaria de Educação Fundamental. Parâmetros curriculares nacionais: apresentação dos temas transversais, ética/Secretaria de Educação Fundamental. Brasília: MEC/SEF, 1997.

BRASIL. Secretaria de Ensino Superior do MEC. Portaria ํㅜ 126, 1 fev. Diretrizes curriculares nacionais dos cursos de graduação em medicina. Diário Oficial 
da União, Brasília, 2 fev, 1999. Disponível em: <http://www.mec.gov.br/ sesu/ftp/Medicina-DC.rtf>. Acesso em: 11 mar. 2003.

BRASIL. Inep/MEC. Exame nacional de cursos. Brasilia. Disponível em: $<\mathrm{http}$ /| /www.inep.gov.br/enc/provao2000/questionario12.html>. Acesso em: dez. 2000.

BRECHT, B. Nada é impossível de mudar. Antologia Poética. Rio de Janeiro: Elo Editora, 1983.

BRENER, C. Noções Básicas de Psicanálise: introdução à psicologia psicanalítica. 3.ed. Rio de Janeiro/São Paulo: Imago/Edusp, 1975.

CALMAN, K. C. \& DOWNIE, R. S. Practical problems in the teaching of ethics to medical students. Journal of Medical Ethics, 13: 153-156, 1987.

CAMPOS, G. W. S. Educação médica, hospitais universitários e o Sistema Único de Saúde. Cadernos de Saúde Pública, 15(1): 187-193, jan.-mar., 1999.

CARAPINHEIRO, G. Saberes e Poderes no Hospital: uma sociologia dos serviços hospitalares. 2.ed. Lisboa: Edições Afrontamento, 1993.

CARSON, R. Teaching ethics in the context of the medical humanities. Journal of Medical Ethics, 20: 235-238, 1994.

CASTORINA, J. A. et al. Piaget - Vygotsky: novas contribuições para o debate. 5.ed. Rio de Janeiro: Ática, 1998.

CHADWICK, R. Encyclopedia of Applied Ethics. San Diego: Academic Press, 1998.

CHANG, E. H. \& POWER, D. V. Are medical students comfortable with practicing physical examinations on each other? Academic Medicine, 75 (4): 384-389, 2000.

CHAVES, M. \& ROSA, A. R. Educação Médica nas Américas: o desafio dos anos 90. São Paulo: Cortez, 1990.

CHRISTAKIS, D. A. \& FEUDTNER, C. Ethics in a short white coat: the ethical dilemmas that medical students confront. Academic Medicine, 68: 249-254, 1993.

COE, R. M. Sociologia de la Medicina. 3.ed. Madri: Alianza Universidad, 1984.

COHEN, D. et al. A national survey concerning the ethical aspects of informed consent and role of medical students. Journal of Medical Education, 63: 821-829, nov., 1988. 
COLES, R. The moral education of medical students. Academic Medicine, 73(1): 55-57, 1998.

CONSELHO FEDERAL DE MEDICINA (CFM). Resolução CFM n 663/75, 12 ago. 1975. Diário Oficial da União, Brasília, Seção l, pt. 11.

CONSELHO REGIONAL DE MEDICINA DO ESPÍRITO SANTO (CRM/ES). Resolução no 029/92, 16jun.1992, Vitória, 1992a.

CONSELHO REGIONAL DE MEDICINA DO ESPÍRITO SANTO (CRM/ES). Resolução oㅡ 032/92, 1 set. 1992, Vitória, 1992b.

CONSELHO REGIONAL DE MEDICINA DA PARAÍBA (CRM/PB). Código de Ética do Estudante de Medicina. João Pessoa: CRM-PB, 1991.

COURA, J. R. Aspectos éticos da prática médica e da investigação clínica. ln: XX CONGRESSO DA SOCIEDADE BRASILEIRA DE MEDICINA TROPICAL, 1984, Salvador. Anais... Salvador, 1984.

CUNHA, L. A. A Universidade Temporã. Rio de Janeiro: Livraria Francisco Alves Editora, 1986.

DAVIS, C. Modelo da aprendizagem social. In: RAPPAPORT, C. R.; FIORI, W. R. \& DAVIS, C. (Orgs.) Teorias do Desenvolvimento: conceitos fundamentais. São Paulo: EPU, 1981.v.1. (1ª reimpressão)

DÉJOURS, C. A Banalização da Injustiça Social. Rio de Janeiro: FGV, 1999.

DRISLANE, R. \& PARKINSON, G. Online Dictionary of the Social Sciences. Athabasca University, 2000. Disponivel em: <http://bitbucket.icaap.org/cgibin/glossary/SocialDict?alpha=S>. Acesso em: nov. 2000.

DRUMMOND, J. P. \& SILVA, E. Medicina Baseada em Evidências: novo paradigma assistencial e pedagógico. São Paulo: Atheneu, 1998.

DUMONT, L. 0 Individualismo: uma perspectiva antropológica. Rio de Janeiro: Rocco, 2000.

DUSKA, R. \& WHELAN, M. O Desenvolvimento Moral na ldade Evolutiva: um guia a Piaget e a Kohlberg. São Paulo: Edições Loyola, 1994.

DWYER, J. Primum non tacere: an ethics of speaking up. Hasting Center Report, 24(1): 13-18, 1994.

ENGELHARDT JR., H. T. The Foundations of Bioethics. 2.ed. Londres: Oxford University Press, 1996. 
ERON, L. Effect of medical education on medical students' attitudes. Journal of Medical Education, 30: 559-566. In: COE, R. M. (Org.) Sociologia de la Medicina. 3.ed. Madri: Alianza Universidad, 1984.

FAULKNER, L. R. \& MCCURDY, R. L. Teaching medical students social responsibility: the right thing to do. Academic Medicine, 75(4): 346-350, 2000.

FERREIRA, A. B. H. Novo Dicionário Aurélio da Língua Portuguesa. 3.ed. Rio de Janeiro: Nova Fronteira, 2000.

FEUDTNER, C. \& CHRISTAKIS, D. A. Making the rounds: the ethical development of medical students in the context of clinical rotations. Hasting Center Report, 24(1): 6-12, 1994.

FIDALG0, A. Semiótica. Disponível em: <http://ubista.ubi.pt/ fidalgo/ fid_semiotica.html.>. Acesso em: nov. 2000.

FOUCAULT, M. O Nascimento da Clínica. Rio de Janeiro: Forense-Universitária, 1987.

FOUCAULT, M. Microfísica do Poder. Rio de Janeiro: Edições Graal, 1988.

F0X, R. C. Essays on Medical Sociology: journeys into the field. 2.ed. New Brunswick/Oxford: Transaction Books, 1988.

FOX, R. C. The Sociology of Medicine: a participant observer's view. New Jersey: Englewood Cliffs, Prentice Hall, 1989.

FRENK, J. Efectos del origen social y de la socialización profesional sobre las preferencias vocacionales de los internos de Medicina de México. Educación Meddica y Salud, 19(4): 426-449, 1985.

GARCIA, J. C. La Educación medica en la America Latina. Washington: Opas, 1972. (Publicação Científica, 255)

GILLIGAN, C. In a Different Voice: psychological theory and women's development. Massachusetts: Harvard University Press, 1998. (35a reimpressão/1.ed., 1982)

GONÇALVES, R. B. Medicina e História: raizes sociais do trabalho médico, 1987. Tese de Doutorado, São Paulo: Departamento de Medicina Preventiva, Faculdade de Medicina da Universidade de São Paulo.

GOODE, W. The theoretical limits of profissonalization. In: ETZIONI, A. (Ed.) The Semi-Professions and their Organization. Londres: The Free Press, 1969. 
GRANT, V. J. Patient involvement in clinical training. Journal of Medical Ethics, 20: 244-250, 1994.

HANSEN, D. T. Teaching and the moral life of classrooms. Journal for a Just and Caring Education, 2: 59-74, 1995.

HÄYRY, H. Paternalism. In: CHADWICK, R. (Ed.) Encyclopedia of Applied Ethics. San Diego: Academic Press, 1998. v.3.

HOLM, S. et al. Changes in moral reasoning and the teaching of medical ethics. Medical Education, 29: 420-423, 1995.

HOSSNE, W. S. Educação médica e ética. In: MARCONDES, E. \& GONÇALVES, E. L. (Orgs.) Educação Médica. São Paulo: Sarvier, 1998.

HUITT, W. \& HUMMEL, J. Social Cognition. Disponível em: <http:// chiron.valdosta.edu/whuitt/col/soccog/soccog.html >. Acesso em: mar. 2003.

JARILLO-SOTO, E. C.; ARROYAVE-LOAIZA, M. G. \& CHAPELA, M. C. Algunas determinantes en la conformación de los patrones profesionales en estudiantes de Medicina. Revista de Salud Pública de México, 34(4): 455466, 1992.

JORNAL DO CREMERJ, Ano XII (122): 20, 2000.

JUNQUEIRA, P. C. Importância dos serviços de urgência na formação médica. Revista Médica do Estado da Guanabara, 33(3): 131-135, 1966.

KANT, E. Traité de Pédagogie. Paris: Hachette, 1981.

KAPP, M. B. Legal implications of clinical supervision of medical students and residents. Journal of Medical Education, 58: 293-299, apr., 1983.

KENDALL, P. L. \& READER, G. G. Innovations in medical education of the 1950 's contrasted with those of the 1970's and 1980's. Journal of Health and Social Behavior, 29: 279-293, dec., 1988.

KLOETZEL, K. Medicina Ambulatorial: princípios básicos. São Paulo: EPU, 1999.

KOHLBERG, L. The Meaning and Measurement of Moral Development. Massachussetts: Clark University Press, 1981.v.13. (Heinz Werner lectures)

KOHLBERG, L. Essays on moral development: the psychology of moral development. In: POWER, F. C.; HIGGINS, A. \& KOHLBERG, L. (Eds.) Lawrence Kohlberg's Approach to Moral Education. Nova lorque: Colúmbia University Press, 1989. 
KONNER, M. Becoming a Doctor: a journey of initiation in medical school. Nova lorque: Penguin Books, 1988.

KOPELMAN, L. M. Philosophy and medical education. Academic Medicine, 70 (9): 795-802, 1995.

KOPELMAN, L. M. Values and virtues: how should they be taught? Academic Medicine, 74(12): 1307-1310, 1999.

KOTTOW, M. Enseñando los paradojos de la autonomia. Revista Brasileira de Educação Médica, 24(3), 2000. (No prelo)

KOTTOW, M. \& SCRHAMM, F. R. Desarrollo moral en bioética: ¿etapas, esquemas o ámbitos morales? Revista Brasileira de Educação Médica, 25(2): 25-31, 2001.

KOTTOW, M. et al. Cambios de actitudes eticas a lo largo de los estudios de Medicina. Revista Medica de Chile, 121:379-384, 1993.

LAPLANCHE, J. Vocabulário da Psicanálise/Laplanche e Pontalis. São Paulo: Martins Fontes, 1995.

LARSON, M. The Rise of Professionalism: sociological analysis. Los Angeles: University of California Press, 1977.

LASCH, C. O Mínimo Eu: sobrevivência psíquica em tempos de crise. São Paulo: Brasiliense, 1986.

LA TAILLE, Y. 0 lugar da interação social na concepção de Piaget. In: LA TAILLE, Y.; OLIVEIRA, M. K. \& DANTAS, H. (Orgs.) Piaget, Vygotsky e Wallon: teorias psicogenéticas em discussão. São Paulo: Summus Editorial, 1992.

LA TAILLE, Y. A educação moral: Kant e Piaget. In: MACEDO, L. (Org.) Cinco Estudos de Educação Moral. São Paulo: Casa do Psicólogo Livraria e Editora, 1996.

LA TAILLE, Y.; OLIVEIRA, M. K. \& DANTAS, H. Piaget, Vygotsky e Wallon: teorias psicogenéticas em discussão. São Paulo: Summus Editorial, 1992.

LIGHT, D. Toward a new sociology of medical education. Journal of Health and Social Behavior, 29: 307-322, dec.,1988.

LIND, G. Moral regression in medical students and their learning environment. Revista Brasileira de Educação Médica, 24(3): 24-33, 2000.

MACEDO, L. (Org.) Cinco Estudos de Educação Moral. São Paulo: Casa do Psicólogo Livraria e Editora, 1996. 
MACHADO, M. H. Os Médicos e sua Prática Profissional: as metamorfoses de uma profissão, 1996. Tese de Doutorado, Rio de Janeiro: luperj.

MACHADO, R. et al. Danação da Norma: medicina social e constituição da psiquiatria no Brasil. Rio de Janeiro: Edições Graal, 1978.

MARCONDES, E. \& GONÇALVES, E. L. Educação Médica. São Paulo: Sanvier, 1998.

MARTIN, L. AÉtica Médica Diante do Paciente Terminal. São Paulo: Santuário, 1993.

MARTIN, S. C.; ARNOLD, R. M. \& PARKER, R. M. Gender and medical socialization. Journal of Health and Social Behavior, 29: 333-343, dec., 1988.

MARTINI, C. Pós-graduação e educação continuada. In: CHAVES, M. \& ROSA, A. R. (Orgs.) Educação Médica nas Américas: o desafio dos anos 90. São Paulo: Cortez, 1990.

MATHEUX, B. \& BÉLAND, F. Changes in students' sociopolitical attitudes during medical school: socialization or maturation effect? Social Science Medical, 24(7): 619-624, 1987.

MATURANA, H. Emoções e Linguagem na Educação e na Política. Belo Horizonte: UFMG, 1998.

MEIRA, A. R. \& CUNHA, M. M. S. C. 0 ensino da ética médica em nível de graduação nas faculdades de Medicina do Brasil. Revista Brasileira de Educação Médica, 18(1):148, 1994.

MELEIRO, A. M. A. S. Suicídio entre médicos e estudantes de medicina. Revista da Associação Médica Brasileira, 44(2): 135-140, 1998.

MERTON, R. K.; READER, G. G. \& KENDALL, P. L. (Eds.) The Student-Physician Introductory Studies in the Sociology of Medical Education. Cambridge: Harvard University Press, 1957.

MILAN, L. et al. O Universo Psicológico do Futuro Médico: vocação, vicissitudes e perspectivas. São Paulo: Casa do Psicólogo, 1999.

MOORE, W. E. The Professions: roles and rules. Nova lorque: Russel Sage Foundation, 1976. (1.ed., 1970)

MORI, M. A bioética: sua natureza e história. Humanidades, 9(4): 332-341, 1994.

MORIN, E. Ciência com Consciência. Rio de Janeiro: Bertrand Brasil, 1996. 
MYSER, C.; KERRIDGE, 1. H. \& MITCHELL, K. R. Teaching clinical ethics as a professional skill: bridging the gap between knowledge about ethics and its use in clinical practice. Journal of Medical Ethics, 21: 97-103, 1995.

NUNES, M. L. T. Moral \& TV. Porto Alegre: Evangraf, 1998.

OXFORD AMERICAN DICTIONARY. Nova lorque: Avon Books, 1982.

PAJARES, F. Self-efficacy beliefs in academic settings. Review of Educational Research, 66(4): 543-578, 1996.

PARKER, M. Autonomy problem-cased learning, and the teaching of medical ethics. Journal of Medical Ethics, 21: 305-310, 1995.

PERESTELLO, D. A. Medicina da Pessoa: abordagem da pessoa e seu adoecer em clínica médica. 2.ed. São Paulo: Atheneu, 1974.

PIAGET, J. A epistemologia genética. In: PIAGET, J. Os Pensadores. São Paulo: Abril Cultural, 1983.

PIAGET, J. Epistemologia Genética. São Paulo: Martins Fontes, 1990.

PIAGET, J. O Juízo Moral na Criança. 2.ed. São Paulo: Summus, 1994.

PIAGET, J. Os procedimentos da educação moral. In: MACEDO, L. (Org.) Cinco Estudos de Educação Moral. São Paulo: Casa do Psicólogo Livraria e Editora, 1996.

PORTO, C. C. et al. Um código de ética para o estudante de Medicina. In: XIV CONGRESSO DA ABEM, XIV, 1976, Rio de Janeiro. Anais... Rio de Janeiro: Abem,1976.

PORT0, C. C. et al. A área afetiva no ensino/aprendizagem da medicina e a formação ética do futuro médico. XVI CONGRESSO DA ABEM, XVI, 1978, Rio de Janeiro. Anais... Rio de Janeiro: Abem, 1978.

POWER, F. C.; HIGGINS, A. \& KOHLBERG, L. Lawrence Kohlberg's Approach to Moral Education. Nova lorque: Colúmbia University Press, 1989.

PUIG, J. M. Ética e Valores: métodos para um ensino transversal. São Paulo: Caso do Psicólogo, 1998.

RAPPAPORT, C. R.; FIORI, W. R. \& DAVIS, C. Teorias do Desenvolvimento: conceitos fundamentais. São Paulo: EPU, 1981.v.1. (1ª reimpressão)

REGO, S. A medicalização do hospital no Brasil: notas de estudo. Revista Médica de Minas Gerais, 3(1): 54-57, 1993. 
REGO, S. A Prática na Formação Médica: os estágios extracurriculares em questão, 1994. Dissertação de Mestrado, Rio de Janeiro: Instituto de Medicina Social, Universidade Estadual do Rio de Janeiro.

REST, J. et al. Postconventional Moral Thinking: a neo-kohlbergian approach. Nova lorque: Lawrence Erlbaum Associates, 1999.

REZENDE, A. L. M. Saúde: dialética do pensar e do fazer. São Paulo: Cortez,1986. ROBINSON, J. Are we teaching students that patients don't matter? Journal of Medical Ethics, 11: 19-21, 1985.

ROSA, M. Psicologia Evolutiva. 8.ed. Petrópolis: Vozes, 1996. v.1.

SANTOS, B. S. Pela Mão de Alice: o social e o político na pós-modernidade. São Paulo: Cortez, 1995.

SANTOS FILHO, L. História Geral da Medicina Brasileira. São Paulo: Hucitec/ Edusp, 1977.

SANTOS, R. F. Parecer 506/69, 11 jul. 1969. In: CONSELHO FEDERAL DE EDUCAÇÃO. Currículos Mínimos dos Cursos de Graduação. Brasília: Ed. MEC, 1981.

SAPIRO, C. M. Teorias em desenvolvimento sociomoral: Piaget, Kohlberg e Turiel - possíveis implicações para a educação moral na educação médica. Revista Brasileira de Educação Médica, 24(3): 3-15, 2000.

SCHRAMM, F. R. A autonomia difícil. Revista de Bioética, 6(1), 1998. Disponível em: <http://www.cfm.org.br/revista/bio 1v6/autodificil.htm>.

SCHRAMM, F. R. Entrevista. In: ABEM. Boletim da Abem, 28(1): 8-13, mar., 2000.

SCHRAMM, F. R. (2001) Comunicação pessoal.

SCLIAR, M. Meu Filho, o Doutor: medicina e judaísmo na história, na literatura e no humor. Porto Alegre: ArtMed, 2001.

SELF, D. J. \& OLIVAREZ, M. The influence of gender on conflicts of interest in the allocation of limited critical care resources: justice versus care. Journal of Critical Care, 8(1): 64-74, 1993.

SELF, D. J. \& BALDWIN, D. C. Moral reasoning in medicine. ln: REST, J. R. \& NARVAEZ, D. (Eds.) Moral Development in the Professions. Hillsdale: Erlbaum, 1994. 
SELF, D. J. \& DAVENPORT, E. Measurement of moral development in medicine. Cambridge Quaterly of Healthcare Ethics, 5: 269-277, 1996.

SELF, D. J. \& OLIVAREZ, M. Retention of moral reasoning skills over the four years of medical education. Teaching and Learning in Medicine, 8(4): 195199, 1996.

SELF, D. J. \& BALDWIN, D. C. Does medical education inhibit the development of moral reasoning in medical students? A cross-sectional study. Academic Medicine, 73(10): S91-S93, 1998.

SELF, D. J. \& SKEEL, J. D. The moral reasoning of HEC members. HEC Forum, 10(1): 43-54, 1998.

SELF, D. J.; WOLINSKY, F. D. \& BALDWIN, D. C. The effect of teaching medical ethics on medical students' moral reasoning. Academic Medicine, 64: 755759, 1989.

SELF, D. J.; BALDWIN, D. C. \& WOLINSKY, F. D. Evaluation of teaching medical ethics by an assessment of moral reasoning. Medical Education, 26: 178184, 1992.

SELF, D. J.; SKEEL, J. D. \& JECKER, N. S. The influence of philosophical versus theological education on the moral development of clinical medical ethicists. Academic Medicine, 68: 848-852, 1993.

SELF, D. J.; SKEEL, J. D. \& JECKER, N. S. A comparison of the moral reasoning of physicians and clinical medical ethicists. Academic Medicine, 68: 852-855, 1993.

SELF, D. J.; BALDWIN, D. C. \& OLIVAREZ, M. Teaching medical ethics to firstyear students by using film discussion to develop their moral reasoning. Academic Medicine, 68(5): 383-385, 1993.

SELF, D. J.; BALDWIN, D. C. \& WOLINSKY, F. D. Further exploration of the relationship between medical education and moral development. Cambridge Quarterly of Health Care Ethics, 5: 444-449, 1996.

SELF, D. J.; OLIVAREZ, M. \& BALDWIN, D. C. The amount of small-group case study discussion needed to improve moral reasoning skills of medical students. Academic Medicine, 73(5): 521-523, 1998.

SELF, D. J.; OLIVAREZ, M. \& BALDWIN, D. C. Clarifying the relationship of medical education and moral development. Academic Medicine, 73(5): 7275, 1998. 
SELF, D. J. et al. The moral development of medical students: a pilot study of the possible influence of medical education. Medical Education, 27: 26-34, 1993.

SENNETT, R. O Declínio do Homem Público: as tiranias da intimidade. São Paulo: Companhia das Letras, 1988.

SHAPIRO, J. \& MILLER, R. How medical students think about ethical issues. Academic Medicine, 69(7): 591-593, 1994.

SHAPIRO, S. L; SHAPIRO, D. E. \& SCHWARTZ, G. E. R. Stress Management in Medical Education: a review of the literature. Academic Medicine, 75(7): 748-759, 2000.

SHELTON, W. Can virtue be taught? Academic Medicine, 74(6): 671-674, 1999.

SHUVAL, J. T. \& ADLER, 1. The roles of models in professional socialization. Social Science and Medicine, 14A: 5-14, 1980.

SILVERMAN, D. R. Narrowing the gap between the rhetoric and reality of medical ethics. Academic Medicine, 71(3): 227-237, 1996.

STARR, P. The Social Transformation of American Medicine. Nova lorque: Basic Books, lnc., Publishers, 1982.

STERNBERG, R. J. Psicologia Cognitiva. Porto Alegre: Artes Médicas Sul, 2000.

TEDESCO, J. C. Sociologia da Educação. 4.ed. Campinas: Autores Associados, 1995.

TURIEL, E. The development of social-conventional and moral concepts. In: WINDMILLER, M.; LAMBERT, N. \& TURIEL, E. (Eds.) Moral Development and Socialization. Boston: Allyin and Bacon, Inc., 1980.

TURIEL, E. The Culture of Morality: social development, context, and conflict. Nova lorque: Cambridge Univesity Press, 2002.

TYSINGER, J. W. et al. Teaching ethics using small-group, problem-based learning. Journal of Medical Ethics, 23: 315-318, 1997.

VARELA, D. Espera na fila. Folha de S. Paulo, São Paulo, 12 ago, 2000.

WEBER, M. A Ética Protestante e o Espírito do Capitalismo. 5.ed. São Paulo: Livraria Pioneira, 1987.

WINDMILLER, M. A guide to moral development and socialization. In: WINDMILLER, M.; LAMBER, N. \& TURIEL, E. (Eds.) Moral Development and Socialization. Boston: Allyn and Bacon, 1980. 
WORLD MEDICAL ASSOCIATION (WMA) Resolution on the inclusion of medical ethics and human rights in the curriculum of medical schools world-wide. In: 51 ${ }^{\text {st }}$ WORLD MEDICAL ASSOCIATION GENERAL ASSEMBLY, 1999, Tel Aviv, lsrael, 1999. Disponível em: <http://www.wma.org>. Acesso em: mar. 2003.

YOUNG, T. A. Teaching medical students to lie. Canadian Medical Association Journal, 156(2): 219-222, 1997. 
Formato: $16 \times 23 \mathrm{~cm}$

Tipologia: Rouen

Papel: Pólen Bold $70 \mathrm{~g} / \mathrm{m}^{2}$ (miolo)

Cartão Supremo $250 \mathrm{~g} / \mathrm{m}^{2}$ (capa)

Fotolitos: Laser vegetal (miolo)

Reimpressão e acabamento: Imos Gráfica e Editora Ltda.

Rio de Janeiro, maio de 2012.

Não encontrando nossos títulos em livrarias,

contactar a EDITORA FIOCRUZ:

Av. Brasil, 4036 - sala 112 - Manguinhos

21040-361 - Rio de Janeiro - RJ

Tel.: (21) 3882-9007 | Telefax: (21) 3882-9006

www.fiocruz.br/editora

e-mail: editora@fiocruz.br 